\title{
Fluvial Sediment of the
}

\section{Mississippi River at}

\section{St. Louis, Missouri}

By PAUL R. JORDAN

GEOLOGICAL SURVEY WATER-SUPPLY PAPER 1802

Prepared in cooperation with the U.S. Army Corps of Engineers

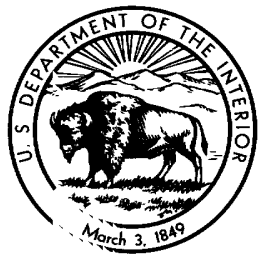


FLUVIAL SEDIMENT MISSISSIPPI RIVER ST. LOUIS, MISSOURI 


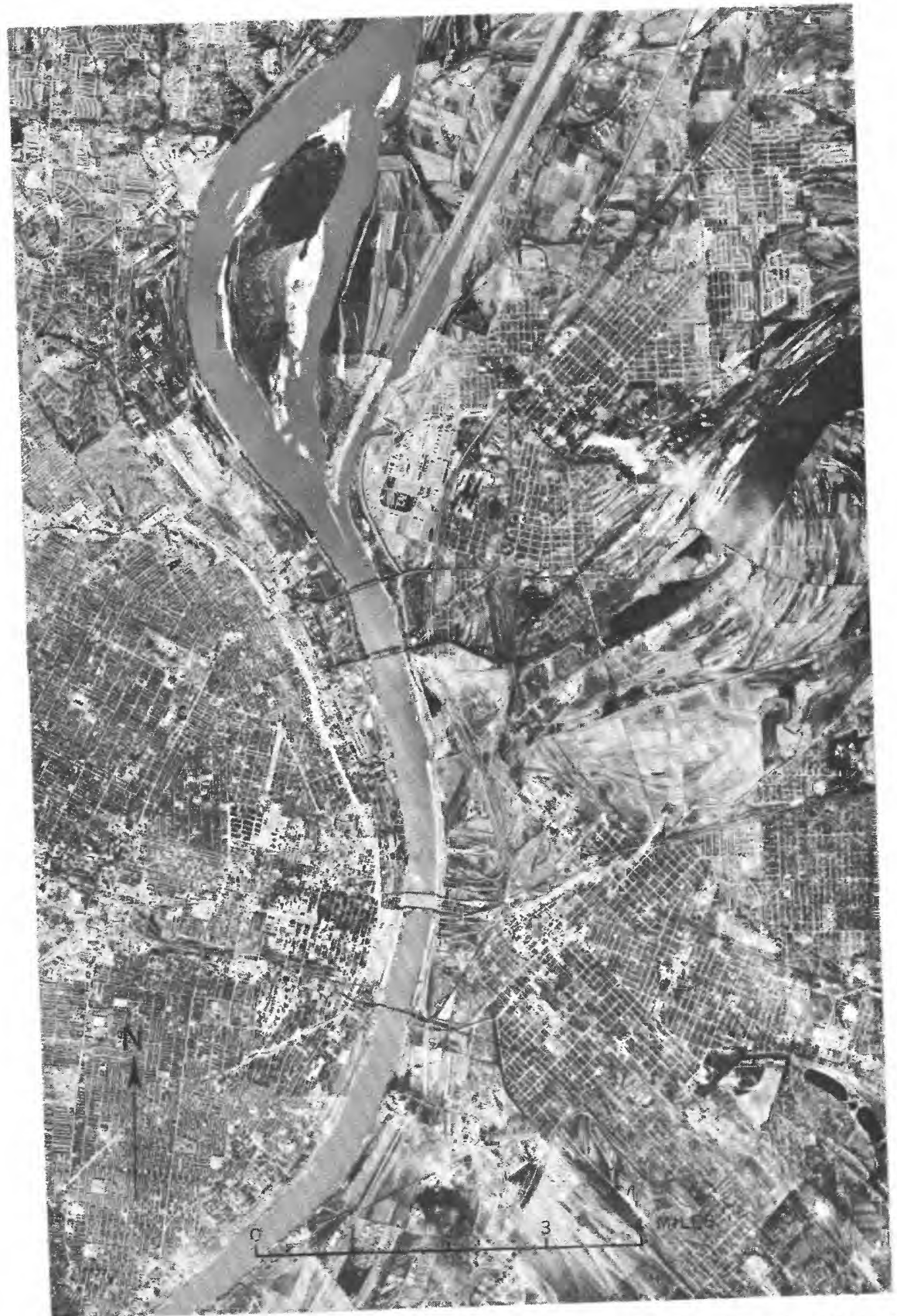

The Mississippi River, part of St. Louis, and East St. Louis. Fluvial sediment and streamflow were measured at the bridge nearest the bottom of the photograph. Photograph by Surdex Corp., St. Louis, Mo. 


\section{UNITED STATES DEPARTMENT OF THE INTERIOF}

\section{STEWART L. UDALL, Secretary}

\section{GEOLOGIGAL SURVEY}

Thomas B. Nolan, Director 


\section{CONTENTS}

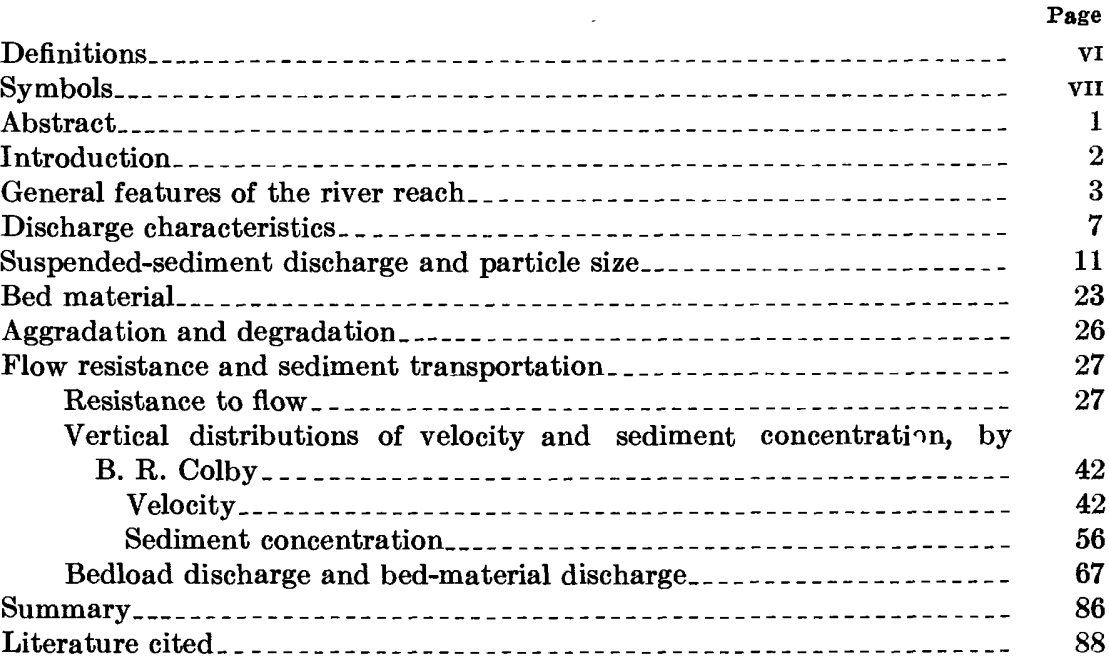

\section{ILLUSTRATIONS}

2. Relation of width, depth, and velocity to discharge $\ldots . . . . . .6$

3. Duration curves of daily flows, Missouri River and Mississippi River

4. Mean monthly discharges, 1934-58

5. Recurrence intervals of annual peak discharges, 1861-1958 _- 10

6. Occurrence of peak discharges, 1861-1958

7. Minimum discharges, 1861-1958

8. Suspended-sediment concentration and discharge, 194?-58 $\ldots \quad 14$

9. Monthly trend of suspended-sediment concentrations and

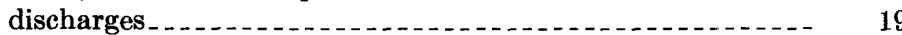

10. Factors affecting mean concentration

11. Relations of suspended-sediment discharge to water discharge_ 22

12. Average and extreme particle-size distributions of susnended sediment.

13. Variation of bed-material size with time

14. Relation of bed-material size to discharge

15. Relation between bed elevation and particle size.......... 27

16. Relation of monthly mean bed elevation to the discharge for 3-month periods. 
Figure 17. Relation of Manning's $n$ to discharge, mean velocity, and shear velocity

18. Relation of $\bar{u} / u_{*}{ }^{\prime \prime}$ to $\Psi^{\prime}$

19. Relation of gage height, bed elevation, and velocity to discharge during major rises in $1951 \ldots \ldots$

20. Effect of sediment on the turbulence constant computed from the vertical distribution of velocity . . . . . . . .

21. $z_{1}$ as a function of $w /\left(k u_{*}\right) \ldots$

22. Relation of measured bed-material discharge to mean velocity and water temperature

23. Bedload discharges computed by various methods ......... 73

24. Bed-material discharges computed by various methods...... 79

25. Comparison of results from different methods of computing bedload discharge . . . . . . . .

26. Comparison of results from different methods of computing

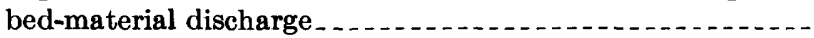

\section{TABLES}

TABLE 1. Monthly and annual summary of streamflow and suspentedsediment discharge, April 1948-September 1958...........

2. Summary of hydraulic and sediment data from concurrent

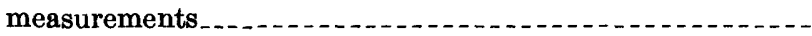

3. Ratios of shear velocity with respect to the grain to shear velocity

4. Vertical distributions of velocity

5. Turbulence constants based on vertical distributions of velocity

6. Values of $z_{1}$ from point samples

7. Particle-size analyses of suspended sediment, point-integrated samples.

8. Computed bedload and bed-material discharges_......... 70

\section{DEFINITIONS}

Bedload discharge. Discharge of sediment that moves in essentially continuous contact with the streambed.

Bed-material discharge. That part of the total sediment discharge consisting of particles whose sizes are the same as those present in significant quantities in the bed.

Discharge (or streamflow). Rate of flow of a stream, expressed as $\varepsilon$ volume or weight per unit time, or the quantity of flow that passes in a given time. It includes the sediment and dissolved solids that are in the water. "Discharge" is the term generally used in this report; streamflow is used where necessary to avoid confusion with various types of sediment discharge. 
Measured bed-material concentration. Ratio of the measured bed-material discharge to the streamflow when both are expressed in weight per unit time.

Measured bed-material discharge. That part of the meisured suspendedsediment discharge consisting of particles whose sizes are the same as those present in significant quantities in the bed.

Measured suspended-sediment discharge. Computed as the product of the concentration of depth-integrated samples, the total discharge, and a constant for converting the units to a weight per unit time, generally tons per day.

Station. A particular location in the cross section at which sediment samples are obtained or hydraulic measurements are made; it is designated by the distance, in feet, from an initial point on the west bank at the MacArthur Bridge. The initial point has remained the same throughout the investigation.

Streamflow. See Discharge.

Total sediment discharge. Weight of all the sediment passing a section in a unit time.

Unmeasured sediment discharge. Difference between the total sediment discharge and the measured suspended-sediment discharge.

\section{SYMBOLS}

a A specified distance above the streambed.

$B$ Mathematical abbreviation for a group of parameters that depend on the particle size.

$b \quad$ Width of flow.

C A constant relating the rate of change of stage to its equivalent effect in the reach.

$c \quad$ Concentration of sediment particles in a size range.

$c_{a} \quad$ Sediment concentration at a distance $a$ above the streambed.

$c_{y} \quad$ Sediment concentration at a distance $y$ above the streambed.

$d \quad$ Grain size of bed material.

$d_{e} \quad$ Effective diameter of bed material, equal to $\Sigma d_{i} i_{b}$ where $d_{i}$ is the average size of particles in a size range and $i_{b}$ is the fraction of material by weight in that size range.

$d_{i} \quad$ Geometric mean size of a bed-material size range.

$d h / d t \quad$ Rate of change of gage height.

$d_{25}, d_{35}, d_{50}, d_{65}, d_{75}, d_{90}$ Particle size at which $25,35,50,65,75$, or 90 percent of the bed material by weight is finer.

$g \quad$ Acceleration due to gravity.

$g_{b} \quad$ "Bed load" according to the definition of Bagnold (1956).

$h_{b} \quad$ Mean bed elevation between stations 275 and 1,800.

$j \quad$ Coefficient in $b=j Q^{m}$.

$k \quad$ Von Karman coefficient for turbulent exchange.

$k_{r} \quad$ Metric coefficient of flow resistance of particles, equal to $26 / d_{90}{ }^{1 / 6}$ where $d_{90}$ is in meters.

$k$. A linear measure of the bed roughness.

$k_{t} \quad$ Metric coefficient of total flow resistance, equal to $\bar{u} / \bar{y}_{0}{ }^{2 / 3} S^{1 / 2}$ where $\bar{u}$ is in meters per second and $\bar{y}_{0}$ is in meters.

$L \quad$ Length between sections at which $Q_{m}$ and $Q_{s}$ are determined.

$\log \quad$ Logarithm to the base 10. 
$m \quad$ Exponent in $b=j Q^{m}$.

$n \quad$ Manning resistance factor, equal to $1.49 R^{2 / 3} S_{e}^{1 / 2} \sqrt{u}$ where $R$ is in feet and $\bar{u}$ is in feet per second.

$n_{d} \quad$ Manning resistance factor during decreasing discharge.

$n_{i} \quad$ Manning resistance factor during increasing discharge.

$p \quad$ Coefficient in $\bar{y}_{0}=\mathrm{pQ}^{r}$.

$p_{i} \quad$ Fraction of bed area occupied by the particles in a size rang 3 , equal to $0.35\left(i_{b} / d_{i}\right) / \Sigma\left(i_{b} / d_{i}\right)$ where $i_{b}$ is the fraction of bed material in a size range and $d_{i}$ is the geometric mean of the size range.

$Q \quad$ Discharge (volumetric streamflow rate).

$Q_{c} \quad$ Discharge under conditions of constant discharge.

$Q_{g} \quad$ Discharge at the gage.

$Q_{m} \quad$ Measured changing discharge.

$q \quad$ Discharge (volumetric streamflow rate) per unit width.

$q_{B M} \quad$ Bed-material discharge per unit width.

$q_{b} \quad$ Bedload discharge per unit width.

$R \quad$ Hydraulic radius.

$r \quad$ Exponent in $\bar{y}_{0}=p Q^{r}$.

$S \quad$ Slope of the water surface for a 6.5 -mile reach.

$S_{c} \quad$ Slope of the water surface under conditions of constant discherge.

$S_{e} \quad$ Energy gradient.

$s \quad$ Coefficient in $\bar{u}=s Q^{t}$.

$t \quad$ Exponent in $\bar{u}=s Q^{t}$.

$U \quad$ Velocity of flood wave.

$\bar{U}_{g} / \bar{U} \quad$ Ratio of the mean speed of movement of grains to mean fluid velocity at the grain level.

$\bar{u} \quad$ Mean velocity of flow in cross section.

$\bar{u}_{c} \quad$ Mean velocity under conditions of constant discharge.

$\bar{u}_{m} \quad$ Measured mean velocity under conditions of changing discharge.

$\bar{u}_{s} \quad$ Mean velocity at a station.

$u_{y} \quad$ Time-averaged velocity of flow at a point a distance $y$ above the streambed.

Shear velocity, equal to $\sqrt{g R S_{e}}$.

$u *$

Shear velocity with respect to the grain.

Shear velocity for channel irregularities such as ripples and dunes.

Average fall velocity of sediment particles in a size range.

A parameter to cover the transition from hydraulically smooth to hydraulically rough boundaries.

$y \quad$ Distance above the streambed.

$y_{0} \quad$ Depth of flow at a station.

$\bar{y}_{0} \quad$ Mean depth of flow in cross section.

Theoretical exponent for vertical distribution of suspended sediment.

Exponent for the actual vertical distribution of suspended sec'iment.

Specific weight of water.

Specific weight of sediment particles.

Sediment characteristic equivalent to Straub's $\Psi$

The particular transporting force required to start movement of the bed material.

Shear function (intensity of shear on representative particle).

$\rho_{s} \quad$ Density of sediment particles. 


\title{
FLUVIAL SEDIMENT OF THE MISSISSIPPI RIVER AT ST. LOUIS, MISSOURI
}

\author{
By Paul R. Jordan
}

\begin{abstract}
An investigation of the fluvial sediment of the Mississippi River at St. Louis, Mo., was begun in 1948. Most data have been obtained only to determine the daily suspended-sediment discharge and the particle-size distribution of suspended sediment and bed material, but a few data have been obtained to study the flow resistance, the vertical distribution of sediment and velocity, and the bed-material discharge.
\end{abstract}

The flow of the Mississippi River at St. Louis is made up of the flows from the Missouri River, which had an average flow of 79,860 cubic feet per second for 1897-1958 at Hermann, Mo., and from the upper Mississippi River, which had an average flow of 91,890 cubic feet per second for 1928-58 at Alton, Ill. The Missouri River is partly controlled by reservoirs that had a total capacity of $90,300,000$ acre-feet in 1956, and the upper Mississippi River is pertly controlled by lakes and reservoirs that had a total capacity of 4,890,000 acre-feet in 1956 .

The flows of the Missouri and upper Mississippi Rivers have not become mixed at St. Louis; so the river has a lateral gradient of suspended-sediment concentration. The concentration near the west bank has been as much as 2,400 parts per million greater than the concentration near the east bank.

Suspended-sediment discharges from April 1948 to September 1958 ranged from 4,250 to 7,010,000 tons per day and averaged 496,000 tons pær day. Mean concentrations for water years decreased steadily from 1,690 parts per million in 1949 to 403 parts per million in 1956 , but they increased to 756 parts per million in 1958. Effects of new reservoirs in the Missouri River basin on the concentration have been obscured by the close relation of concentration to streamflow.

Measured suspended-sediment discharge through September $19^{\text {e }} 8$ averaged 47 percent clay, 38 percent silt, and 15 percent sand. Variations of particle size were due mainly to differences in the source areas of the sediment.

Most of the bed material in the main flow was between 0.125 and 1.000 millimeter in diameter. The average of median diameters was related to the discharge for periods of 1 year and longer. Geometric quartile deviations of the bed material ranged from 1.1 to 2.5 and averaged 1.5.

The mean elevation of the bed had a range of almost 10 feet $\varepsilon$ nd was related to the median diameter of bed material by the regression equetion $h_{b}=\mathbf{3 6 3 . 0}$ $-7.8 d_{50}$ for which the standard error of estimate was 0.91 foot.

The resistance to flow as measured by Manning's $n$ ranged from 0.024 to 0.041 and was related to the discharge and mean velocity but not to the shear velocity. Normal dune height is 2-8 feet, and average dune length is about $2 \% 0$ feet. When the resistance to flow was low, much of the bed was fairly flat; a few dunes were 
present, but they were much longer than the average. For a giver discharge during individual rises in stage, the gage height was lower for increasing discharge than for decreasing discharge even though the bed elevation was higher. The changes in gage height were not caused by changes in energy gradiant due to changing discharge, by channel storage between the gage and the measuring section, nor by return of overbank flow; but they were probably caused by a combination of changes in roughness due to changing bed configuration and of changes in turbulence constant due to changing sediment concentration.

Turbulence constants (Von Karman's $k$ ) computed from velocity measurements at 5-10 points in the vertical and from routine velocity measurements at 2 points in the vertical averaged 0.35 and 0.33 , respectively.

The exponent $z_{1}$ of the vertical distribution of concentration for different size ranges varied with about the 0.77 power of the fall velocity. Except for the difference between the theoretical variation and the actual variation of $z_{1}$ with changing fall velocity, the theoretical equation for the vertical dist-ibution of sediment concentration seems to apply reasonably well for the Missisisiopi River at St. Louis.

The accuracy of methods for computing bedload discharge and bed-material discharge could not be evaluated directly but was evaluated from th e relations of computed bedload discharge or bed-material discharge to the meesured part of the bed-material discharge and to mean velocity. These relations indicated that bedload discharges can be computed most accurately by using tr e modified Einstein, Schoklitsch, and Meyer-Peter and Muller methods as comoared with the Kalinske and Bagnold methods. The relations indicated that bed-material discharges can be computed most accurately by adding the unmeasuret sediment discharge from Colby's procedure to the measured part of the bed-material discharge when data on velocity, concentration, and particle-size distribution are available, or by using Straub's equation when such data are not available. Measured suspended-sediment discharge averaged about 95 percent of the total sediment discharge, and bed-material discharge averaged about 14 percent.

\section{INTRODUCTION}

The Mississippi River is constantly changing its channel ky cutting into its banks, building bars, and aggrading or degrading its bed. Any major changes, either natural or artificial, in the shape or alinement of the channel involve the transportation and redistribution of billions of tons of sediment. The greatest part of the sediment that is being transported by the river will be carried to the deltes beyond the mouth; but a large amount of sediment will be deposited in bars, some of which will eventually become part of the flood plein as the course of the river shifts. Knowledge of the amount and behavior of the sediment is necessary for the planning, construction, and maintenance of works for control and use of the river or its flood plain such as for navigation, waste disposal, water supplies, and flood control.

The investigation to provide the necessary knowledge of fluvial sediment at St. Louis began in April 1948 with the collection of data on suspended-sediment concentration and discharge. Data on particle size of suspended sediment and bed material have been 
collected since 1950 and 1951, respectively. Data on water temperature have been obtained since 1951. Although most of the data were obtained only to determine the daily suspended-sediment discharge and the particle-size distribution of suspended sediment and bed material rather than to study the mechanics of sediment transportation, a few data were obtained to study the vertical distribution of sediment and velocity, the bed-material discharge, and the flow resistance caused by bed-material grains and by dunes and other irregularities on the bed. The data on sediment concentrations and discharges, particle size, and water temperature are published in the annual series of U.S. Geological Survey water-supply papers entitled, "Quality of Surface Waters of the United States."

The purposes of this report are to evaluate and interpret the sediment data, to show the effect of upstream developments on sediment concentration and discharge, and to present some theoretical aspects of sediment transportation as applied to the river. This report includes evaluation of the data obtained through September 1958 and the results of some special studies in 1959 and 1960.

This investigation was made by the U.S. Geological Survey under the successive supervision of P. C. Benedict, regional engineer, and D. M. Culbertson, district engineer. It was made in cooperation with the U.S. Army Corps of Engineers, St. Louis District, who did much of the laboratory analysis of concentration and particle size, provided gage readings for determination of water-surface slopes, and provided results of sonic-fathometer measurements of the configuration of the bed.

The only previously published report that includes information on the fluvial sediment of the Mississippi River in the vicinity of St. Louis is a study of the water resources of the St. Louis area (Searcy, Baker, and Durum, 1952), which gives results of turbidity measurements and of some sediment analyses.

The symbols used in this report conform, where practicable, to those established by the American Standards Association (1958).

\section{GENERAL FEATURES OF THE RIVER REA CH}

The flow of the Mississippi River at St. Louis is a comfosite of the flows from many tributaries in a drainage area of about 701,000 square miles. An average of about 45 percent of the flow at St. Louis is from the Missouri River, which is confluent with the Mississippi River about 15 miles upstream from St. Louis.

The sediment is sampled and streamflow is measured at the MacArthur Bridge, 178.9 miles upstream from the mouth of the Ohio River and 1.1 miles downstream from the water-stage recorder. Because the flow is confined between artificially stabilized banks and 
levees, the channel in the vicinity of MacArthur Bridge is not typical of the channel between the Missouri and Ohio Rivers. At normal river stages, the channel from about $4 \frac{1}{2}$ miles upstream to about 4 miles downstream from the bridge is slightly curved and is nearly uniform in width. (See frontispiece.) The width of flow at the bridge varies from about 1,500 feet at low stage to about 1,800 feet at the highest stage that is confined within the banks. When the flow is over the banks, the width increases, sometimes to more than 2,800 feet. The mean depth of the flow ranges from about 15 to 50 feet.

In the vicinity of the sampling section, the west bank is riprapped, the east bank is subject to scour, and the flow is affected by two bridge piers, each 27 feet wide. The distribution of sediment and the elevation of the streambed are locally affected by barges that move through the section and that are sometimes moored just upstream from the bridge near either bank.

At St. Louis, the flows of the Missouri and upper Mississippi Rivers are not homogeneously mixed, and, because the Missouri River usually has a higher concentration of suspended sediment than does the upper Mississippi, each flow can generally be identified by the appearance of the water. The difference in concentration has evoked the comments of many observers. Chambers (1910, p. 189) wrote that he "saw the coffee-coloured flood of the Missouri add itself to the clear water of the Mississippi. As far as Saint Louis, the western third of the broad river remained café au lait in hue." Figure 1 shows the appearance of the Missouri River water as it enters the Mississippi.

The discharge and the sediment concentration and particle size are major determinants of the shape of the cross section of a channel. According to Leopold and Maddock (1953), up to the bank-full stage in a natural river section, the relations of width, depth, and velocity to discharge are in the mathematical form of simple power functions. The relative rates of increase of width, depth, and velocity are determined by the shape of the channel, the slope of the water surface, and the roughness of the wetted perimeter. The relations shown by Leopold and Maddock for natural river cross se ${ }^{\text {rtions }}$ are, in the notation of this report,

where

$$
\begin{aligned}
b & =j Q^{m} \\
\bar{y} & =p Q^{r} \\
\bar{u} & =s Q^{i}
\end{aligned}
$$

$b$ is width of flow

$Q$ is discharge

$\bar{y}_{0}$ is mean depth of flow in the cross section

$\bar{u}$ is mean velocity of flow in the cross section

$j, m, p, r, s$, and $t$ are constants for a particular cross section 


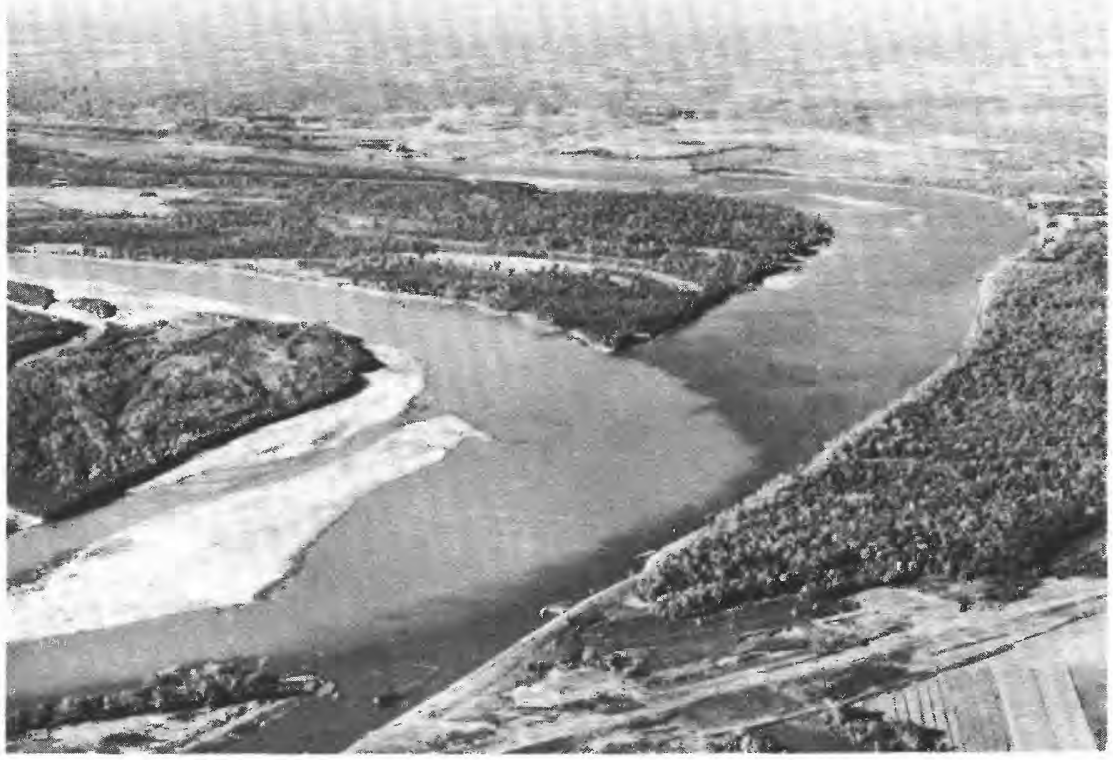

Figure 1.-Confluence of Missouri and Mississippi Rivers. Photograph by Massie-Missouri Resources Division.

Widths, mean depths, and mean velocities of the Mississippi River at St. Louis were plotted against the corresponding discharges on logarithmic graph paper (fig. 2). Straight lines were drawn to fit the plotted points; and slopes $m=0.07, r=0.43$, and $t=0.50$ were measured directly from the graphs. The value of $m(0.07)$ is much less than the average (0.26) given by Leopold and Maddock (1953), because the banks of the Mississippi at St. Louis are artificially stabilized to a rather steep slope.

Leopold and Maddock asserted that because of the identity

then

$$
Q=b \bar{y}_{0} \bar{u}
$$

and it follows that

$$
Q=j Q^{m} p Q^{r} s Q^{t}
$$

and

$$
m+r+t=1.0
$$

$$
j p s=1.0
$$

For the average lines that were drawn to fit the Mississippi River data,

and

$$
\begin{aligned}
m+r+t & =0.07+0.43+0.50 \\
& =1.00
\end{aligned}
$$

$$
\begin{aligned}
j p s & =(680)(0.16)(0.0092) \\
& =1.00
\end{aligned}
$$


FLUVIAL SEDIMENT, MISSISSIPPI RIVER, ST. LOUIS
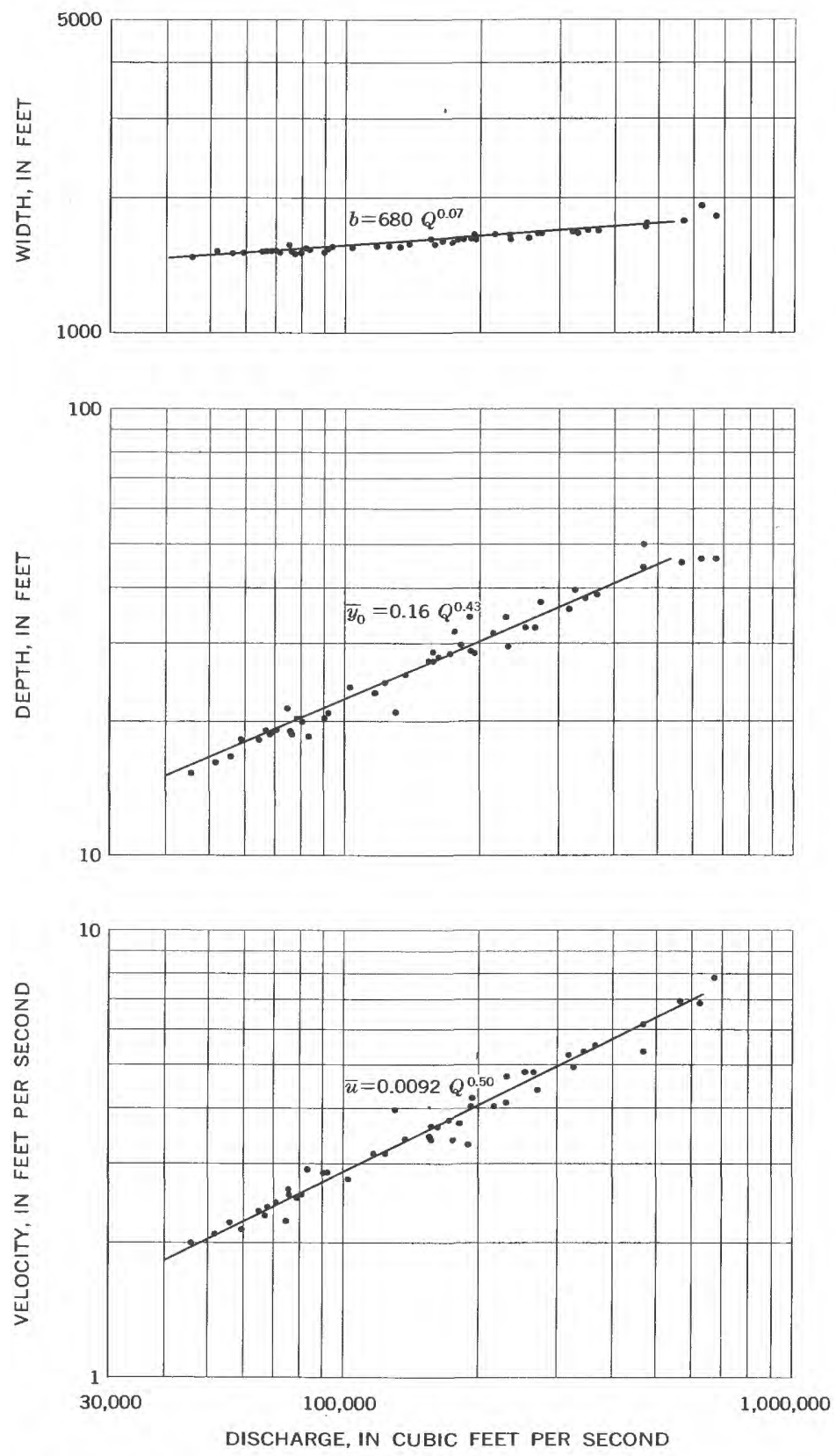

FIGURe 2.-Relation of width, depth, and velocity to discharge. 


\section{DISCHARGE CHARACTERISTICS}

The discharge of the Missouri River near its mouth, at Hermann, Mo., averaged 79,860 cfs (cubic feet per second) for 18ะ7-1958. As of 1956, the Missouri River was partly controlled by reservoirs having capacities totaling about $90,300,000$ acre-feet, of which about 51,300,000 acre-feet was on the main stem of the Missouri River upstream from Yankton, S. Dak. (Storage-capacity figures were computed from Thomas and Harbeck, 1956.) Thus, tho major part of the control of the river is in the upper half of the basin, where floods are caused mainly by mountain and plains snowmelt.

Mississippi River at Alton, Ill., 7.7 miles upstream from the Missouri River, had a mean discharge of $91,890 \mathrm{cfs}$ for $1928-58$. The river is partly regulated by a series of 26 dams that provide slackwater navigation to St. Paul, Minn., and by several reservoirs and lakes on the main stem and the tributaries. Total capacity of the reservoirs and lakes in 1956 was about 4,890,000 acre-fect.

Comparison of the flow-duration curves for Mississippi River at Alton and for Missouri River at Hermann (fig. 3) indic tes that the flow of the Missouri River is more variable than the flow of the Mississippi and that the low flow, particularly in 1929-58, was not well sustained. The low flow of the Missouri River wes better sustained in 1949-58 than in 1929-58 partly because the 1953-56 drought was not so severe as the 1931-35 drought and mainly because a large volume of stored water was released in 1953-56 (Pafford, 1959), particularly from Fort Peck Reservoir, which began storage in 1938 . Comparison of all the curves shows the effects of the flows of the Missouri River and upper Mississippi River on the flow at St. Louis. The similarity of the two curves for each station indic tes that the flow for the period of sediment record is representative of the flow for the past 25-30 years. However, although the mean discharge at St. Louis may be about the same in the future as in the past $(174,800$ cfs for 1861-1958), the high and low flows will probably be less extreme because of the reservoir storage that has been added in recent years.

The discharge at St. Louis follows a definite monthly pattern. (See fig. 4.) Discharges are usually high during March--July because of runoff from snowmelt in the mountains and plains and from spring and early summer rains.

Extremely high flows carry the most sediment, both in suspension and along the bed, and they cause the greatest changis in channel patterns by cutting the banks, depositing sediment in b`rs and overflow areas, and scouring the bed, particularly around bridge piers. Because high sediment concentrations are associated with high flows, 


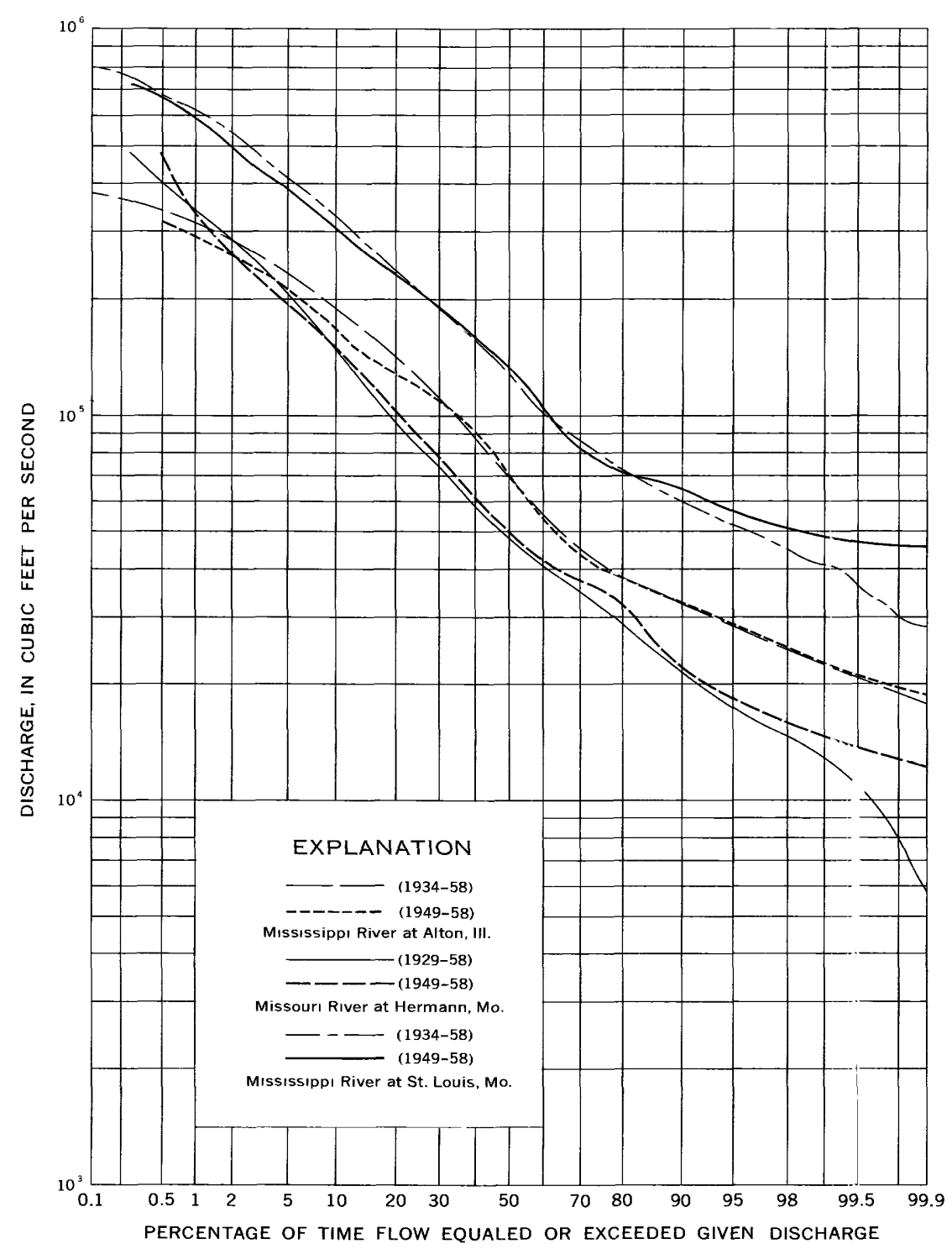

Figure 3.-Duration curves of daily flows, Missouri River and Mississippi River.

the proportion of sediment discharge during a given period of high flow to sediment discharge for the year is larger than the proportion of streamflow during the period to streamflow for the year. In some small rivers, as much as 60 percent of the water and 90 percent of the sediment for the year have been discharged during a few days of high flow; and in the Mississippi River, as much as 17 percent of 


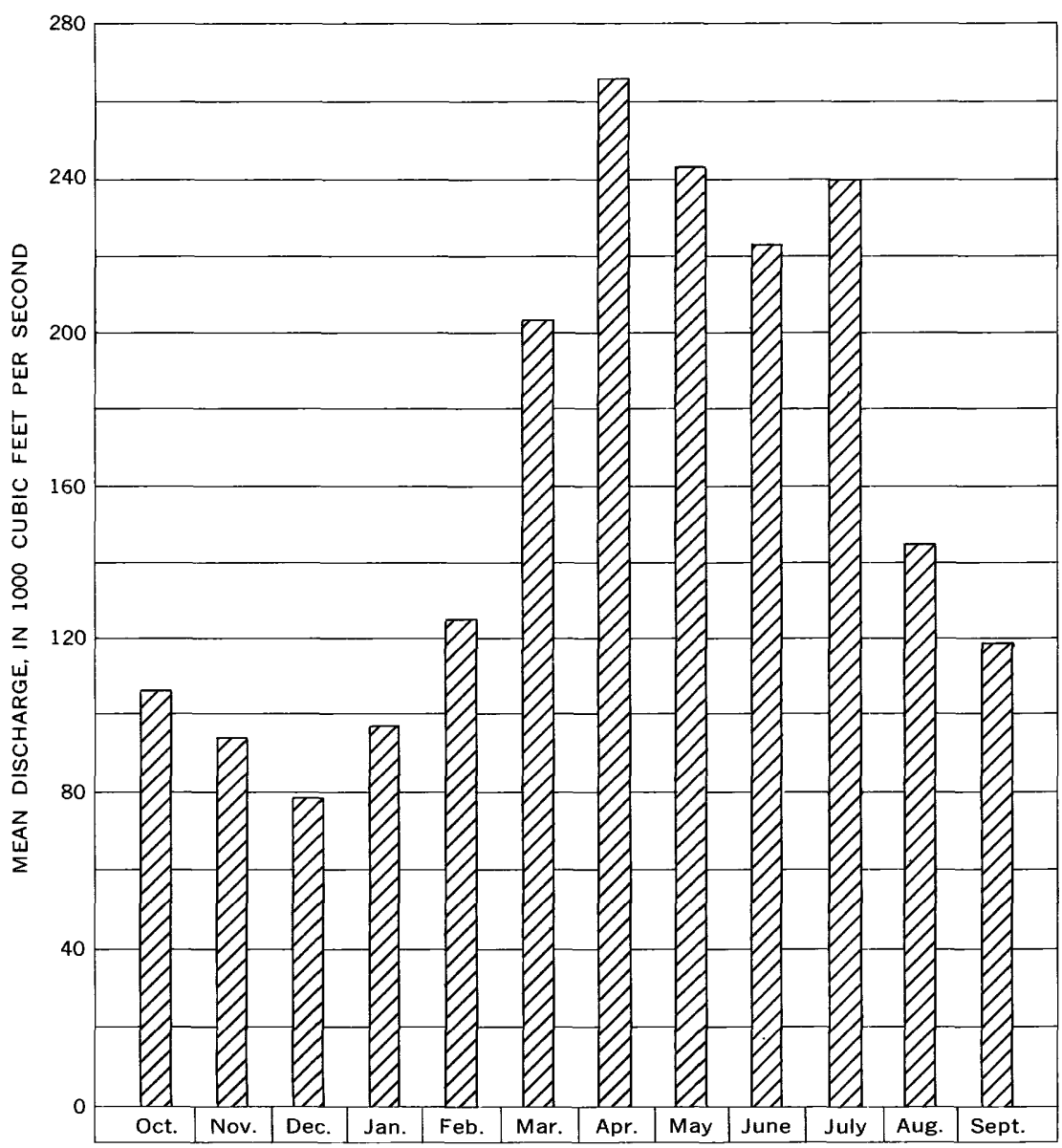

Figure 4.-Mean monthly discharges, 1934-58.

the water and 41 percent of the sediment for the year have been discharged during a 30-day period.

Because of the significance of high flows in transporting sediment, a graph that shows the average recurrence interval of annual peak discharges is presented (fig. 5). The points that are plotted in figure 5 represent the annual peak discharges from 1861 to 1958 , and the curve of figure 5 was derived from graphs of peak discharges presented by Searcy (1955, figs. 11, 12). The curve of figure 5 shows that the peak discharge in July 1951 of 782,000 cfs would have an average recurrence interval of about 9 years and that the peak discharge in April 1952 of $684,000 \mathrm{cfs}$ would have an average recurrence interval of about 5 years. According to the curve, a discharge of 990,000 cfs or more would occur once in 100 years; actually, discharges of more 


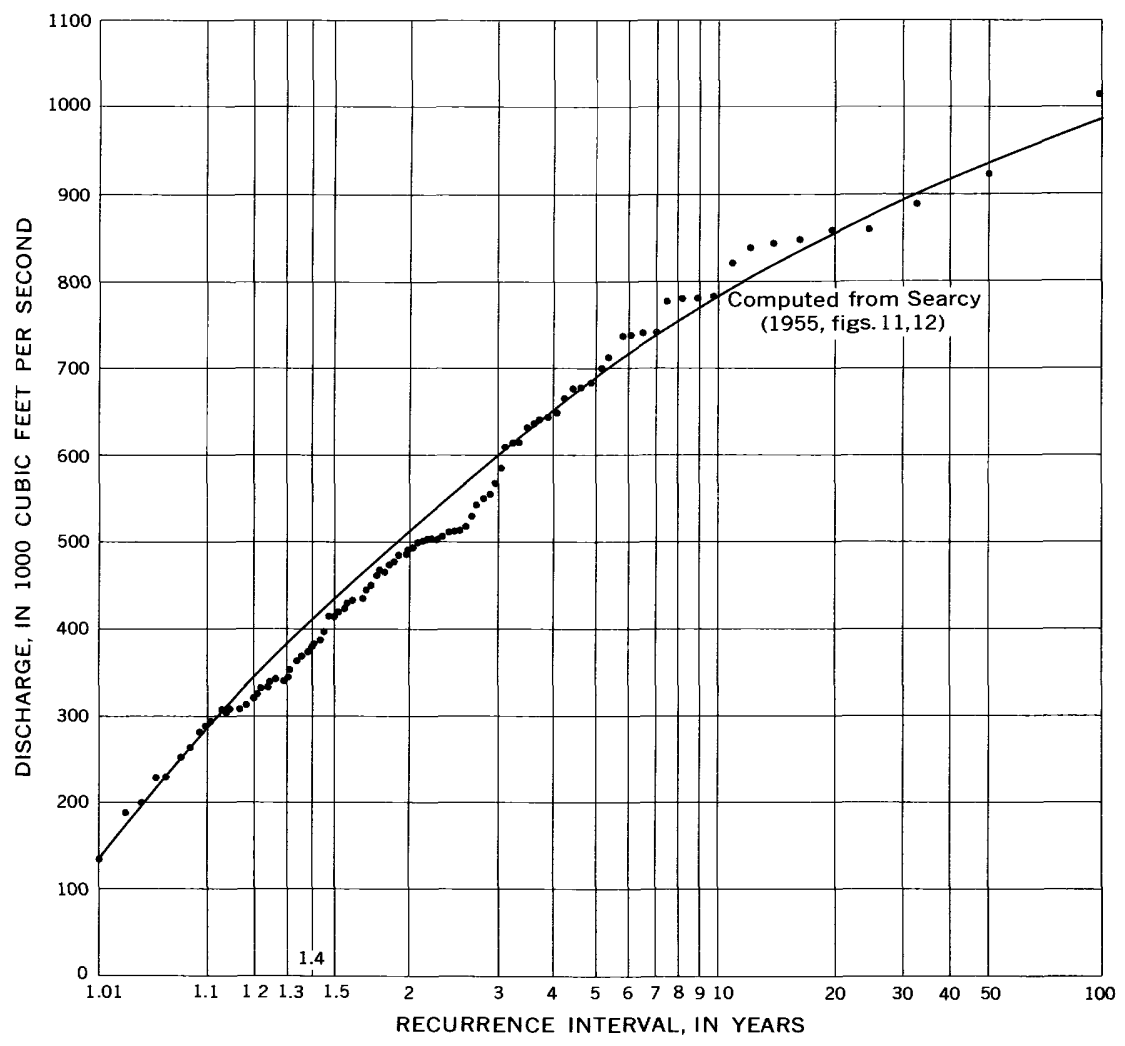

Frgure 5.-Recurrence intervals of annual peak discharges, 1861-1958.

than 990,000 cfs have occurred twice in 184 years (in 1844 and in 1903).

Because of the increased storage capacity that has been added in recent years, particularly in the Missouri River basin, the floodfrequency curve that has been developed from past records probably does not represent accurately the frequencies of future flood?. Most of the floods from the upper Missouri River drainage, such as the one that resulted from snowmelt in April 1952, will be greatly reduced by the reservoirs on the main stem of the Missouri River. Some floods from the lower Missouri River drainage, such as the one that resulted from heavy rains in July 1951, will be reduced by storag ${ }_{3}$ behind dams that have been recently completed or are under construction on many of the tributaries. Also, peak sediment discharges will be reduced by the reservoirs. Most of the annual peak water discharges have occurred in April, May, and June; and many have occurred in July. (See fig. 6.) 


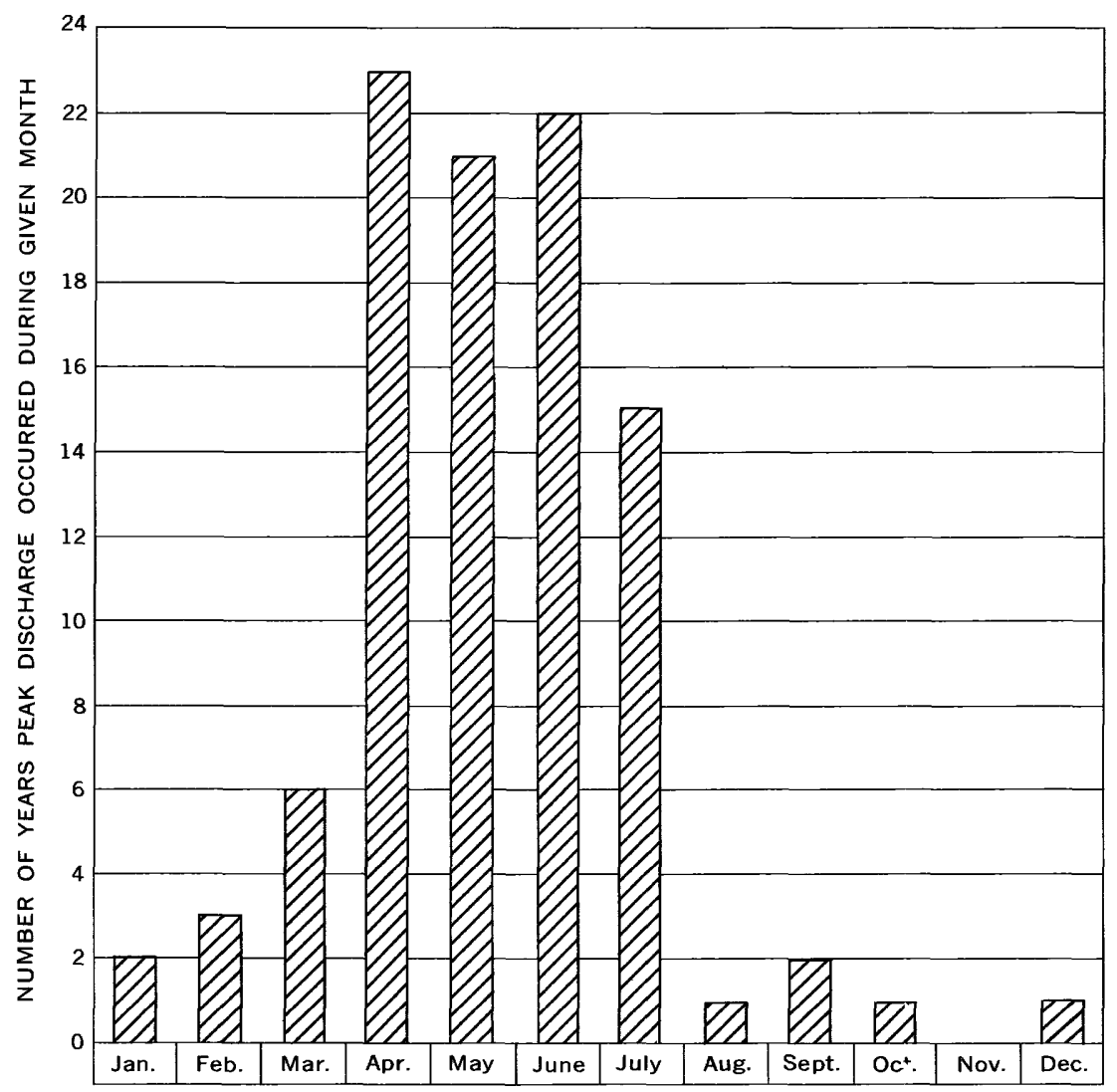

Figure 6.-Occurrence of peak discharges, 1861-1958.

The Mississippi River is subject to periods of low flow, particularly in November-January. Bars built up from the large amounts of sediment that were transported during high flows become obstructions to river traffic during extremely low flows; a 9-foot channel cannot be maintained at all places, and barges cannot be loaded as heavily as usual. Figure 7 shows the magnitude and duration of low flows for the period 1861-1958. Low flows are likely to be less extreme in the future than in the past because of the storage that has recently become available in the Missouri River basin and that can be used to sustain the flow.

\section{SUSPENDED-SEDIMENT DISCHARGE AND PARTICLE SIZE}

Samples of suspended sediment were collected by standard procedures of the Geological Survey. All point-integrated samples and most depth-integrated samples were obtained with a U.S. P-46 sampler suspended from a power-operated reel. At times of high 


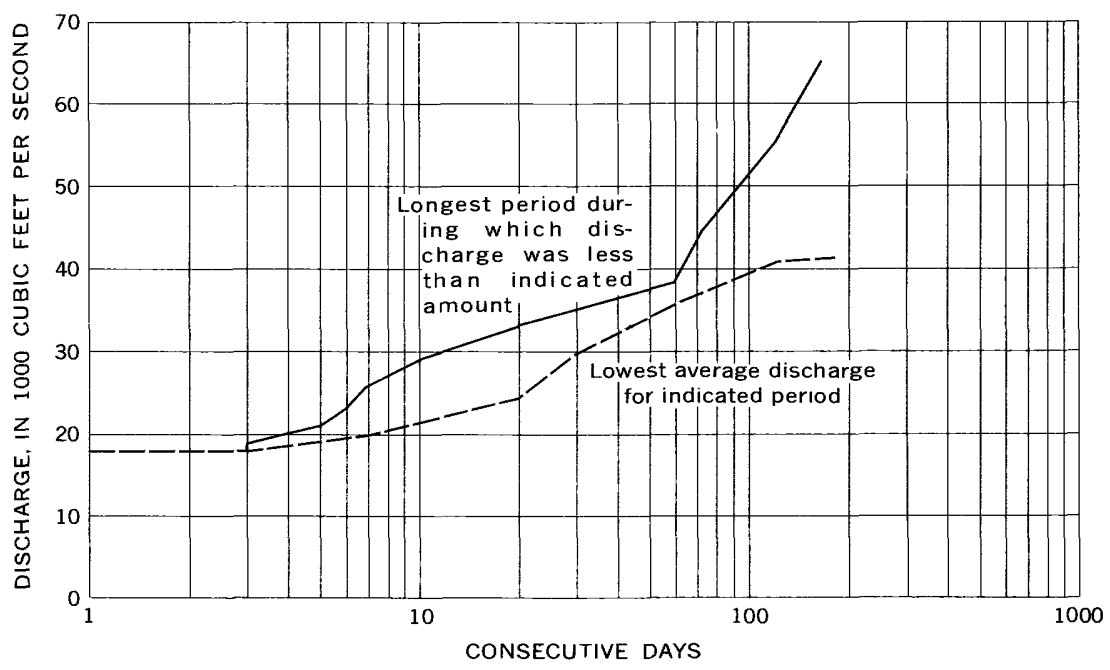

FIGURE 7.-Minimum discharges, 1861-1958.

flow, a 100- or 200-pound weight was attached below the sempler to stabilize it. When heavy floating ice prevented the use of the P-46 sampler, the upper 10 percent of the flow was sampled with a U.S. D-43 sampler. Depth-integrated samples were obtained at, 2, 8, or 10 stations in the cross section to define stream concentrations. Usually, stations were chosen at centroids of equal portions of flow as defined by streamflow measurements. On a few occasions the stations were chosen at points of equal spacing relative to stream $w^{i}$ th, and at these times equal transit rates of the sampler were used.

All suspended-sediment samples were analyzed for concentration, and the results are expressed in parts per million by weight. All the point-integrated samples and some of the depth-integrated samples were analyzed for particle size. Particle-size analyses of depthintegrated samples generally were for composites of samples taken at 8-10 stations. Before October 1952, the bottom-withdrawal-tube method was used for all particle-size analyses of suspended sediment. From October 1952 to May 1955, for most analyses, a bottom-withdrawal tube was used for particles smaller than $0.062 \mathrm{~mm}$ and sieves were used for particles larger than $0.062 \mathrm{~mm}$; for a few analyses, a bottom-withdrawal tube was used alone. Subsequent to May 1955, either a bottom-withdrawal tube or a pipet was used for particles smaller than $0.062 \mathrm{~mm}$, and either sieves or a visual-accumulation tube was used for particles larger than $0.062 \mathrm{~mm}$. Results from the bottom-withdrawal-tube, pipet, and visual-accumulation-tube methods are expressed in terms of fall diameter, which is defined (InterAgency Committee on Water Resources, 1958) as the diameter of a 
sphere that has a specific gravity of 2.65 and has the same standard fall velocity as the particle. Results from the sieve anclyses are expressed in terms of sieve diameter, which is the length of the side of the smallest square opening through which the given particle will pass.

Suspended-sediment samplers currently available cannot obtain samples that are representative of the total sediment discharge. The P-46 sampler can obtain samples from the water surface to about 0.5 foot above the bed or, when the 100- or 200-pound weight is attached, from the water surface to about 1.8 feet above the bed. Therefore, the part of the total sediment discharge that is suspended within 0.5 foot (sometimes $1.8 \mathrm{ft}$ ) of the bed or that is slicing or rolling in almost continuous contact with the bed is not samplet.

The sediment concentration obtained from depth-integrated samples for a cross section is the discharge-weighted mean concentration in the sampled zone. This concentration is multiplied by the discharge for the entire depth and by a units-conversion factor, and the result is called the measured suspended-sediment discharge. If the concentration in the sampled zone is equal to the suspended-sediment concentration for the entire depth, the measured suspended-sediment discharge is equal to the total suspended-sediment discharge; but because the concentration, especially of sand, increase toward the bed, the measured suspended-sediment discharge nornally is less than the total suspended-sediment discharge.

In the Mississippi River, the unsampled zone is only 1-5 percent of the total depth; and even though the concentration of sand increases substantially toward the bed, most of the material in suspension is finer than sand and is nearly uniformly distributed ir the vertical direction. Therefore, the measured suspended-sediment discharge is nearly equal to the total suspended-sediment discharge, and the particle-size distribution of the depth-integrated samples is nearly the same as that for the entire depth. In the following discussion, the term "suspended-sediment discharge" is used to refer to the measured suspended-sediment discharge, which is a close approximation of the total suspended-sediment discharge; and the term "mean concentration" is used to refer to the discharge-weighted mean concentration, either for an individual sample, for the cross section, or for a time period.

Because the flows of the Missouri and Mississippi Rivers have not become mixed at the sampling section, the river has a lateral gradient of suspended-sediment concentration. The concentration near the east bank is usually fairly low, and the concentretion increases progressively toward the west bank. Differences between concentrations at stations near the west bank and near the enst bank have 
been as much as $2,400 \mathrm{ppm}$ (parts per million), and at many times the difference has been greater than the mean concentration for the cross section. As the discharge and mean concentration increase, the lateral concentration gradient increases slightly but the percentage change in concentration decreases. The concentration gradient has no apparent relation to the proportion of the flow that is from the Missouri River or from the upper Mississippi River. Only very infrequently have concentrations near the east bank beer greater than those near the west bank.

Suspended-sediment discharges at St. Louis from April 1948 to September 1958 (see table 1) ranged from 4,250 to 7,010,000 tons per day and averaged 496,000 tons per day. The annual sediment discharges and concentrations are shown in figure 8. Mean concentrations for water years decreased steadily from $1,690 \mathrm{ppm}$ in 1949 to $403 \mathrm{ppm}$ in 1956, but they increased to $756 \mathrm{ppm}$ in 1958 . The monthly trend of suspended-sediment discharges and concentrations (fig. 9) is similar to that of streamflow (fig. 4). The highest su>pendedsediment discharges and concentrations are generally in April-July (frequently in June), and the lowest are in November-February.

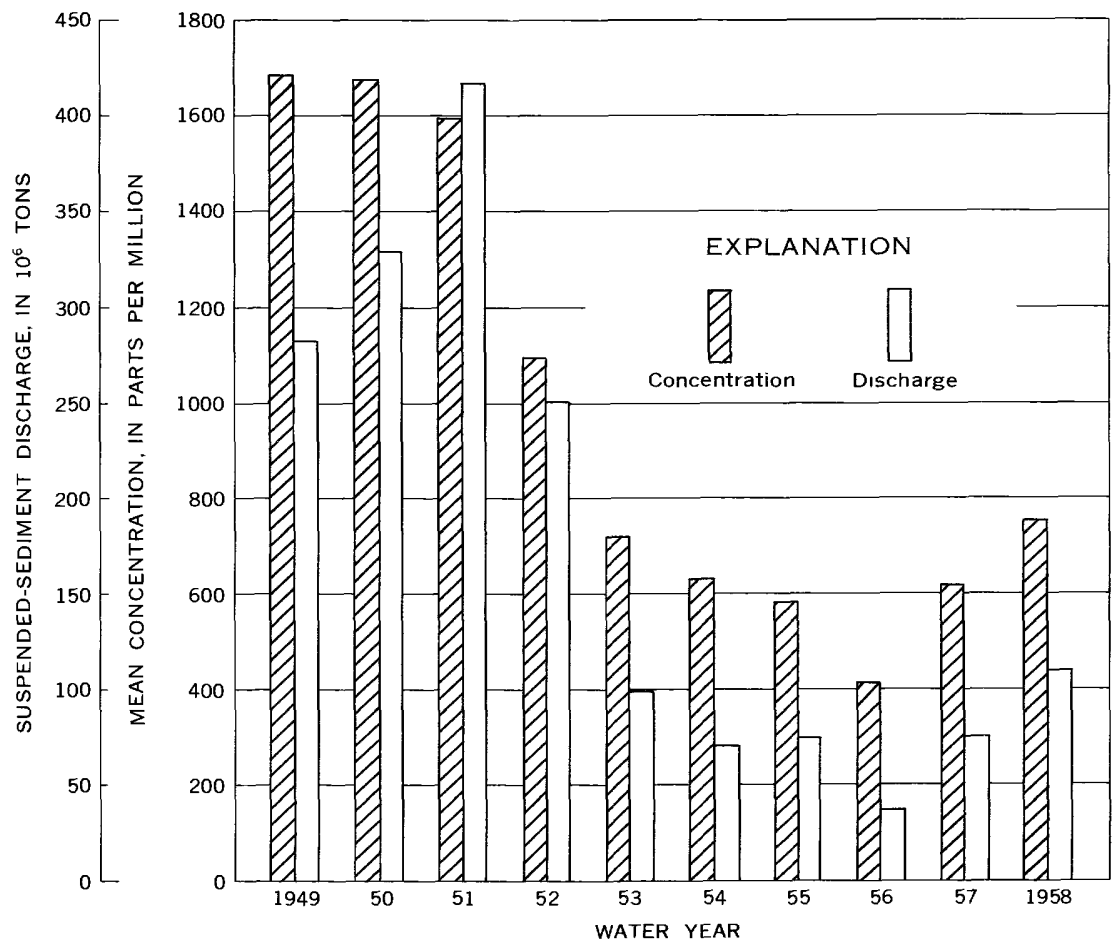

FigURe 8.-Suspended-sediment concentration and discharge, 1949-58. 


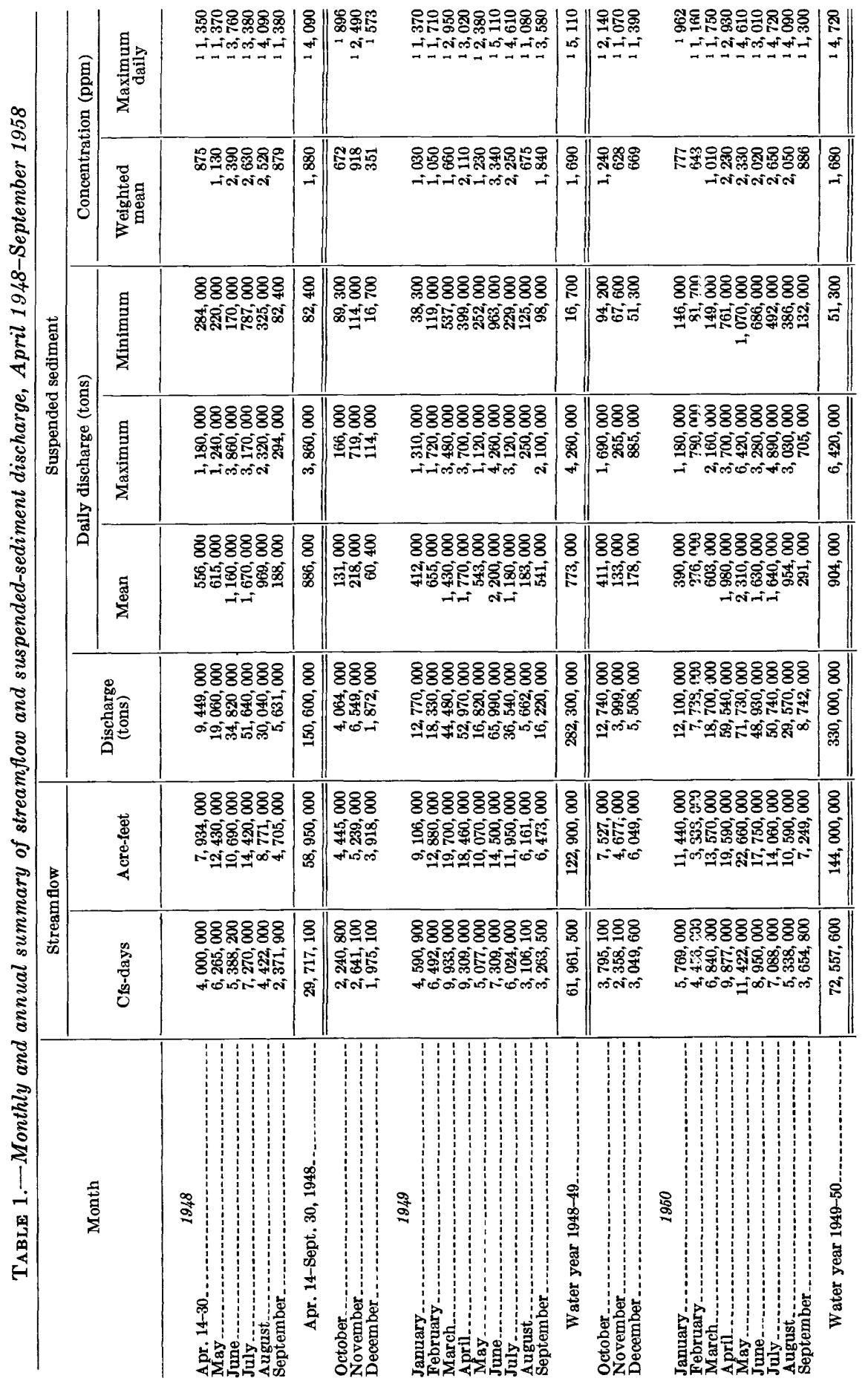




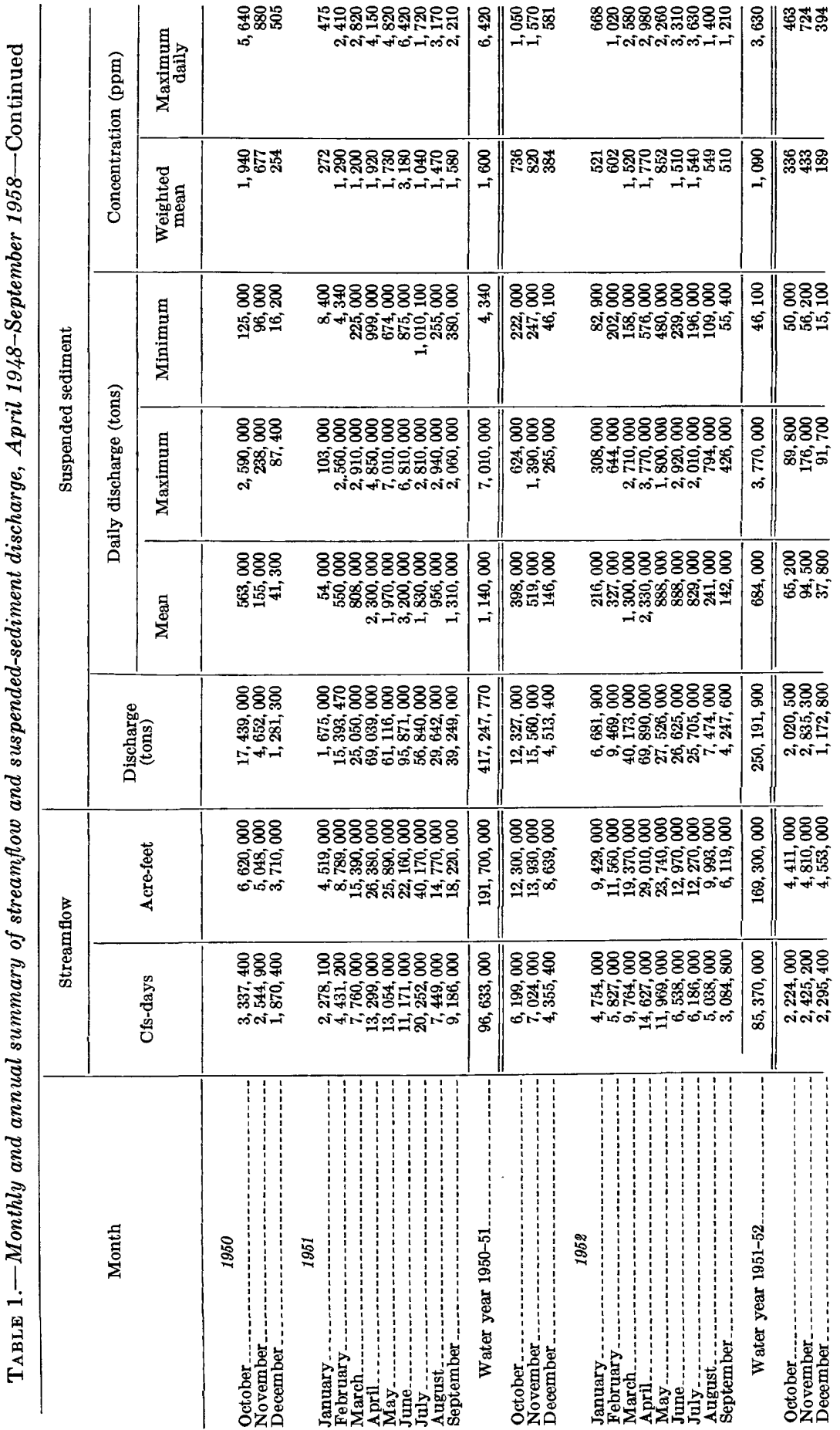




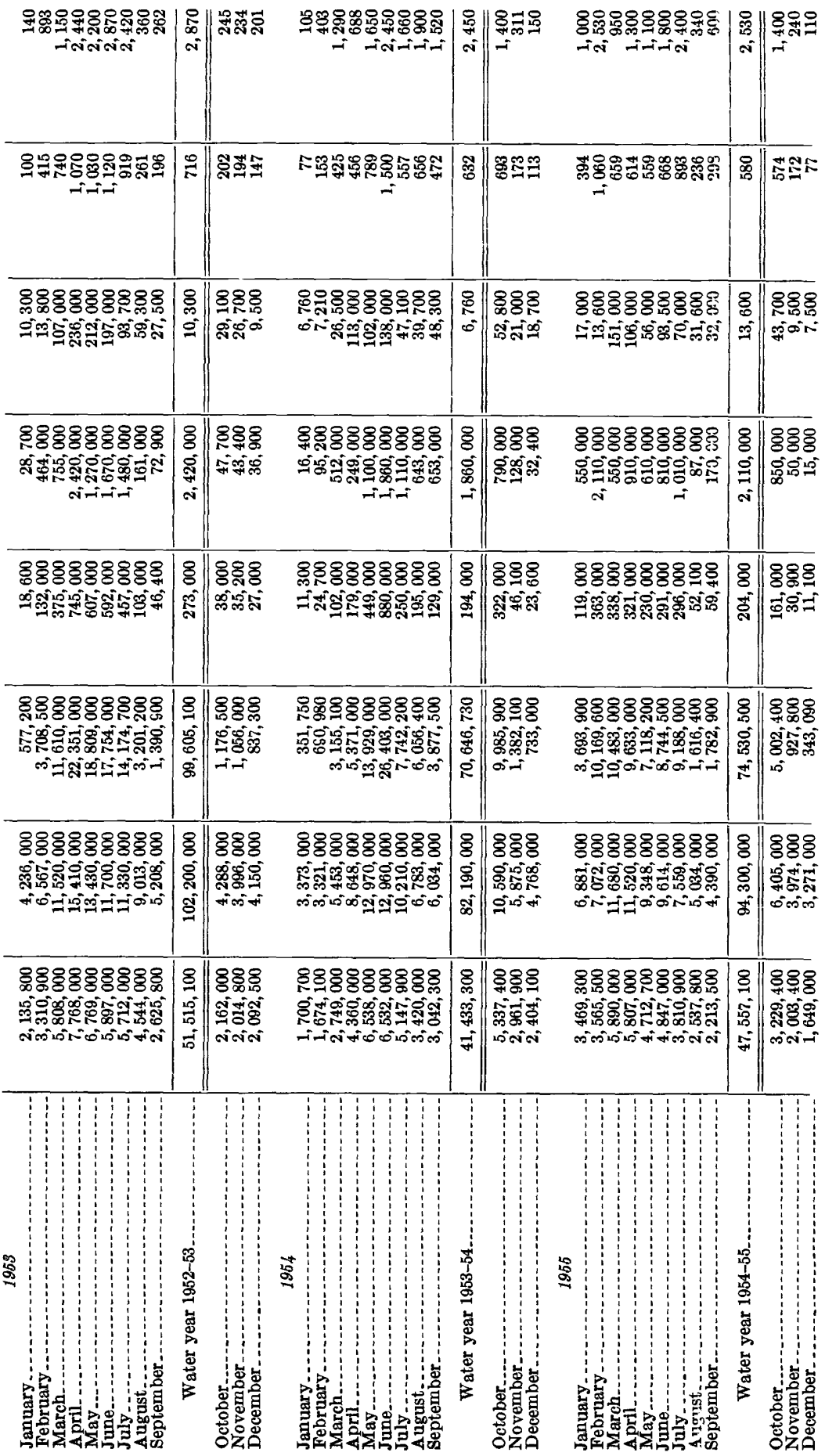


FLUVIAL SEDIMENT, MISSISSIPPI RIVER, ST. LOUIS

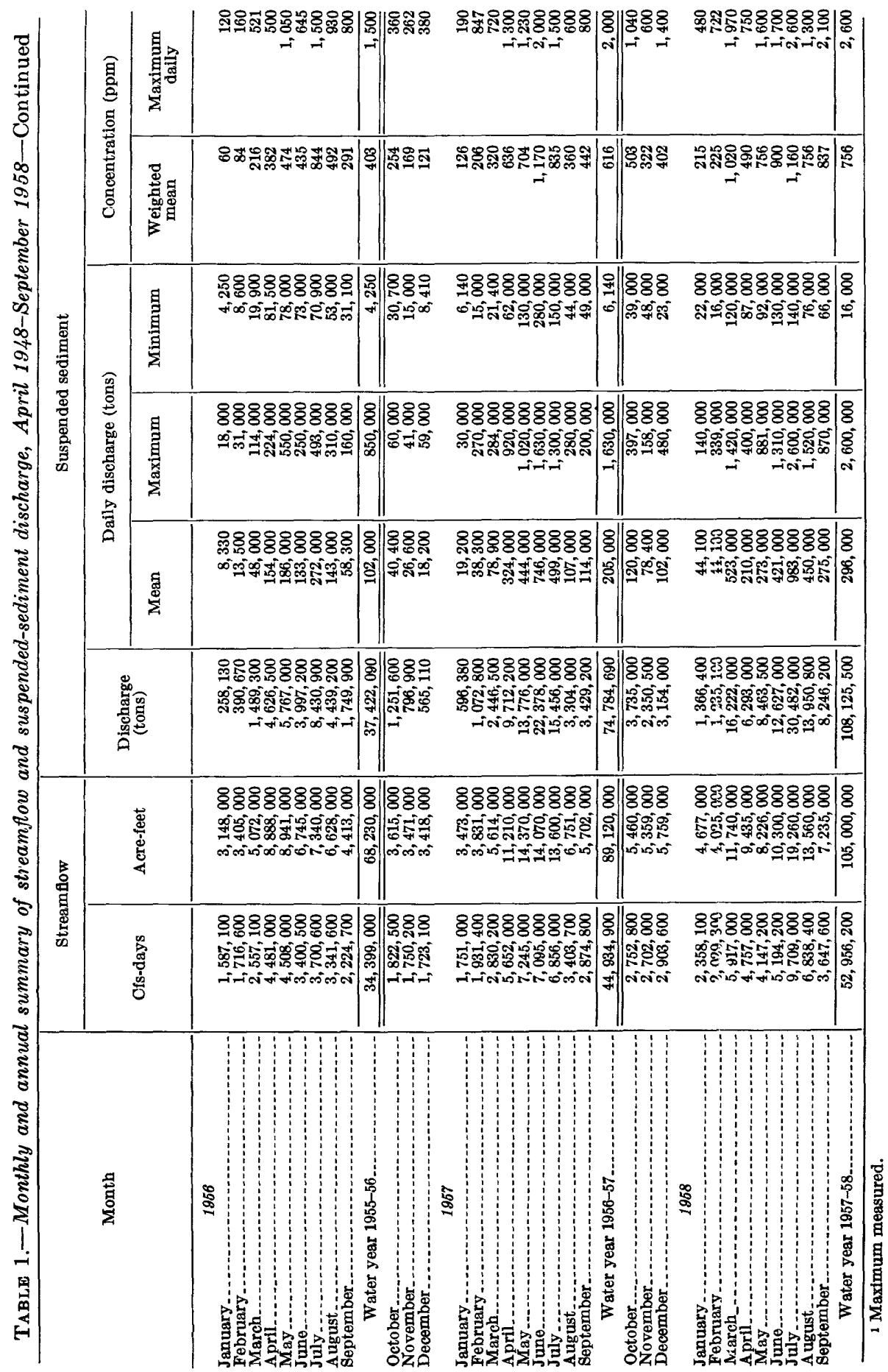




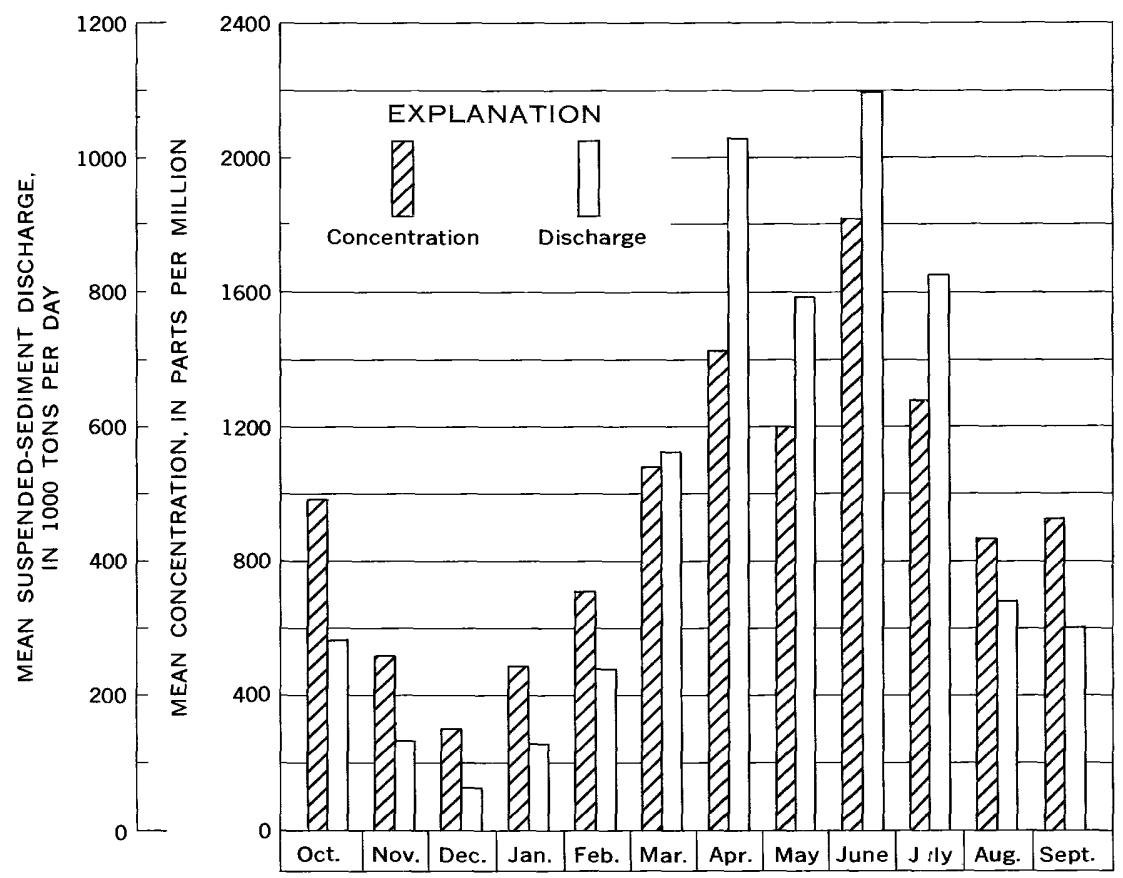

FIGURE 9.--Monthly trend of suspended-sediment concentrations and discharges.

Because of the pronounced decrease in mean concentration from 1949 to 1956 , a study was made to determine whether or not the decrease was the result of retention of sediment behind dams that have recently been completed, particularly in the upper Missouri River basin.

The yearly mean concentration is not closely related to the reservoir storage capacity. (See fig. 10.) The storage capacity was fairly constant from 1948 to the beginning of 1952 ; howeve* the mean concentration decreased appreciably. Also, the storage capacity was much greater in 1954 and 1955 than in previous years, l it the mean concentrations were only slightly less.

One reason why the concentration has no apparent close relation to the storage capacity is that any capacity added urstream from existing storage would have little effect on the concentration at St. Louis. The concentration is expected to be more closely related to the amount of uncontrolled drainage area than to the storage capacity. Figure 10 shows, however, that the concentration is no more closely related to the amount of uncontrolled drainage area than it is to the storage capacity. The only major change in the uncontrolled drainage area was near the beginning of the 1953 water year, when storage 


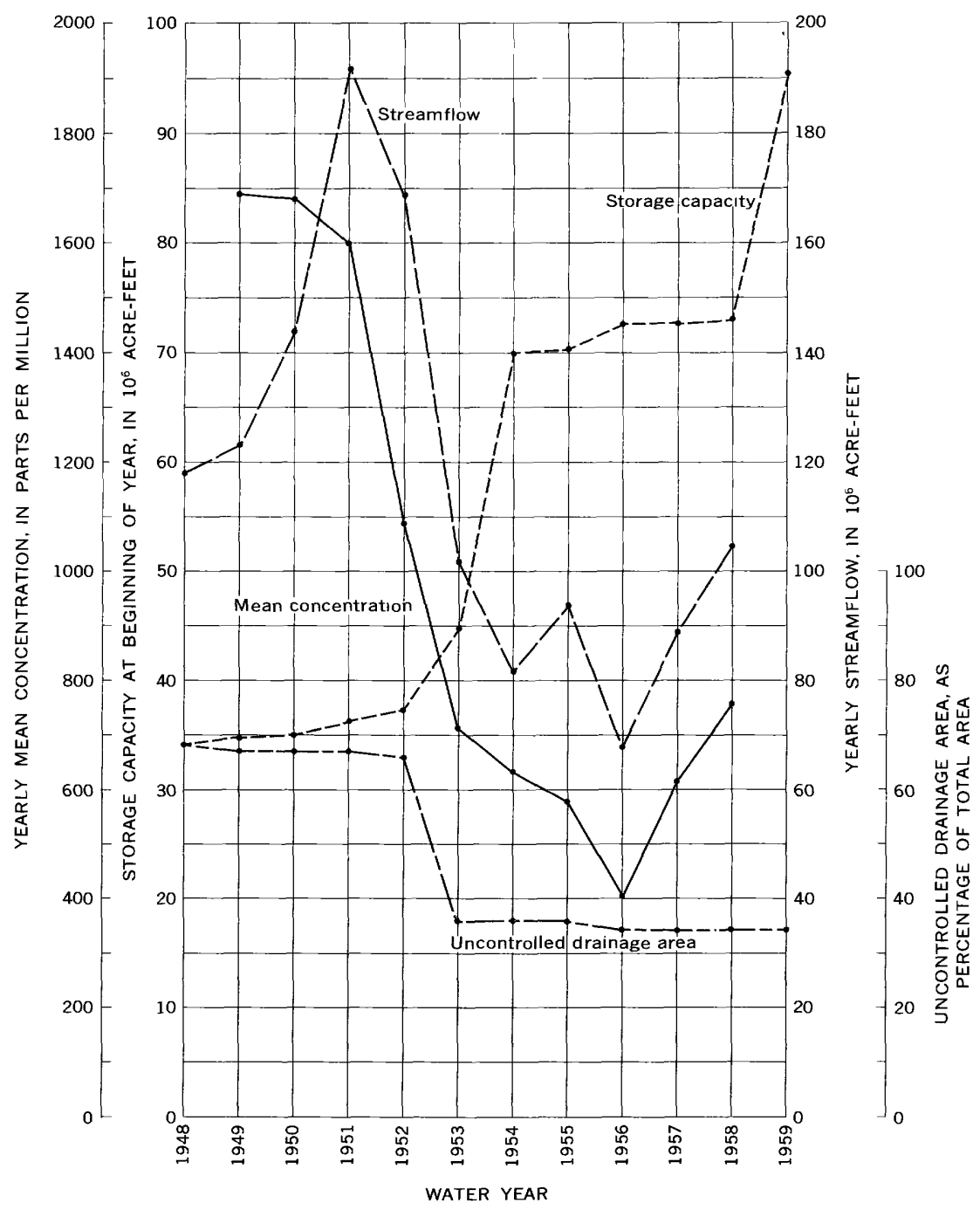

FIGURE 10.-Factors affecting mean concentration.

began at Fort Randall; however, a pronounced decrease in mean concentration took place before 1953 .

Except for the first 3 years of sediment record, the mean concentration followed closely the trend of streamflow. (See fig. 10.) Even though the mean concentration is probably affected by the reservoir storage capacity and by the amount of uncontrolled drainsge area, the effects are obscured by the close relation of concentration to streamflow. Because the river can pick up material from its bed and banks, the effects of storage on the sediment concentration may not 
be apparent as far downstream as St. Louis until many years after the beginning of storage.

A study was made to determine whether or not the relation of suspended-sediment discharge to streamflow had been changed by the upstream storage reservoirs. Measured suspended-sedinent discharges were plotted against the corresponding water discharges, and a line was drawn to represent the relation for each year of record. (See fig. 11.) The lines were not intended to be rating curves but were intended to be only lines of general trend.

From 1949 to 1952 the sediment discharge varied with the 2.0-2.4 power of the water discharge. However, from 1953 to 1956 the sediment discharge varied with the 2.9-3.6 power of the water discharge. In 1957 and 1958 the relations were close to those of $1949-52$; the sediment discharge varied with the 2.5 and 2.3 powers of the water discharge. The sediment discharges at any given water discharge, however, were generally lower in 1957-58 than in 1949-52. Low water discharges carried less sediment in 1953-56 than in other years, but high water discharges carried more sediment. The results of this study are inconclusive, but they seem to indicate that the trend is toward lower sediment discharges for a given water discharge and, therefore, toward lower yearly mean concentrations.

Suspended sediment from depth-integrated samples representing the entire cross section at St. Louis averaged 47 percent clay, 38 percent silt, and 15 percent sand when analyzed, chemically and mechanically dispersed, in distilled water. The average size distribution of suspended sediment and the smallest and largest percent-finer values that were determined for each size are shown in figure 12.

Logically, particle-size distribution of suspended sediment would be related to discharge, season, temperature, and concentration. The amount of sand would increase as discharge increases because the capacity of the flow to transport sand would increase. The amount of silt and clay would increase when surface runoff laden with silt and clay causes the discharge to increase. Normally, the percentage of silt and clay would be less in the winter than in other seasons because surface runoff would be less. The percentage of sand generally would increase as temperature decreases because the high fluid viscosity at low temperature favors high transport capacities for sand. The percentage of silt and clay generally would increase as concentration increases because the amount of silt and clay is not governed by flow conditions and can increase at a faster rate than the amount of sand. The particle-size distribution must also be governed by the widely different sources of sediment in the large drainage area; however, information for determining the source of the sediment was not available. 


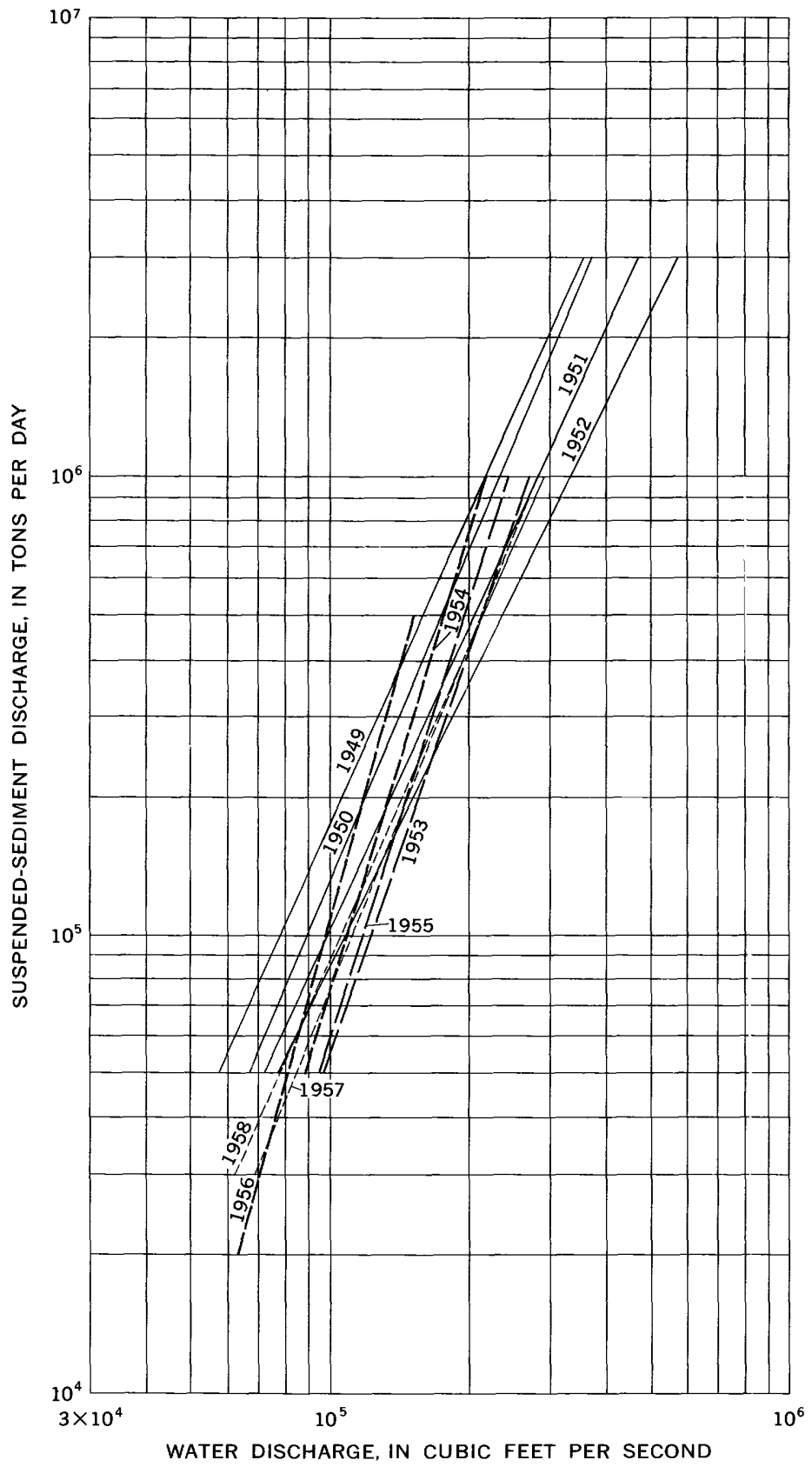

Figure 11.-Relations of suspended-sediment discharge to weter discharge. 


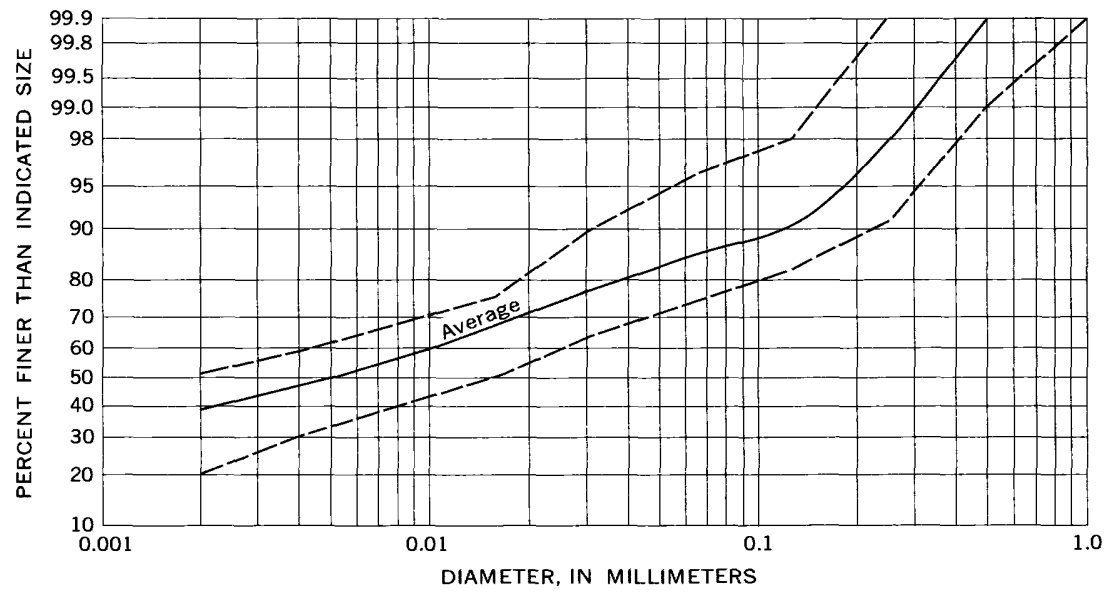

Figure 12.-Average and extreme particle-size distributions of suspended sediment.

No consistent relationships were found from grapbs in which various particle-size parameters were plotted with discherge, season, temperature, and concentration as independent variables. The expected relationships of particle size to discharge, season, and temperature probably exist but were obscured by the variatior of particle size with source area. The expected relationship of particle size to concentration was obscured by the variation of partic's size with source area and by the narrow range of variation of concentration.

Because of the lateral change of concentration in the cross section, a lateral change in particle size would be expected. Such a change can be determined only from analyses of samples from individual stations; however, most of the particle-size analyses were for composites rather than for individual samples. From the few analyses of individual samples, no consistent variation in particla size from one side of the river to the other could be detected.

\section{BED MATERIAL}

Samples of bed material were obtained with a U.S. BM-48 sampler from May 1951 to March 1958 and with a U.S. BM-54 sampler from April 1958 to July 1959. Both samplers obtain material from the upper 1-1 $1 \frac{1}{2}$ inches of the bed. Because of improved desionn, the BM54 sampler is less likely than the BM-48 to permit fine material to be washed out as the sample is taken and raised to the bridge. Samples were obtained at 4 points in the cross section from May 1951 to April 1955 and at 10-21 points from May 1955 to July 1959. 
Before April 1956, the sieve method was used to analyze all bedmaterial samples. Since that time, sieve and visual-accumulationtube methods have been used. Samples were analyzed individually, and the results were averaged to give the particle-size distribution for the entire cross section.

The size distribution of bed material is highly variable with location in the cross section. Near the banks, the material is mostly fine sand and some silt. Near the piers, the material is very coarse; some of the particles are large enough to be retained on a $32-\mathrm{mm}$ sieve. In the main flow, most of the material is between 0.125 and $1.000 \mathrm{~mm}$ in diameter.

The size distribution of bed material is also highly variable with time. (See fig. 13.) The data for four sampling points are shown for $1955-59$ in figure 13 to indicate the probable reliability of the 1951-55 data. The data for 4 sampling points have more variation than those for 10-21 sampling points and are not completely reliable for individual days; however, they show the trend of bed-material sizes rather well. Figure 13 indicates that the median diameters were

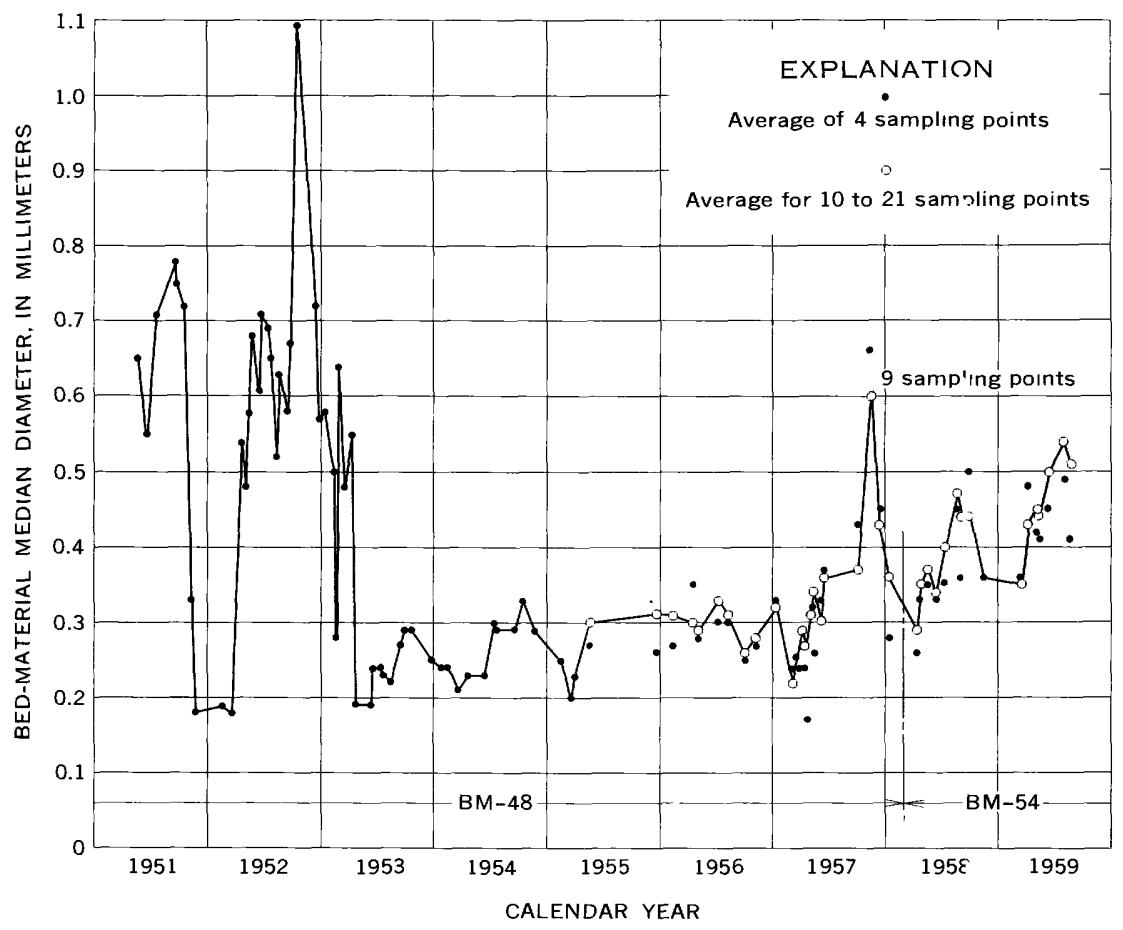

Figure 13.-Variation of bed-material size with time. 
larger in 1951 and 1952 than in 1953-56 and were generally increasing in $1957-59$.

A general relation between median diameter and discharge is suggested by the fact that the discharge was higher in 1951 and 1952 than in 1953-56 and was intermediate in 1957-59. A study was made to determine whether or not the particle size is related to the discharge for short periods. Average median dirmeters were plotted against mean discharge for 1-day to 2-year periods, and 1 year was the shortest period for which a good relation was found. The relation for 2-year periods is slightly better than the relation for 1-year periods (fig. 14). The absence of short-term relations of median diameter to discharge suggests that the bed-material size is influenced more by the depth of scour than by the selective removal or deposition of fine and medium sands from the upper few millimeters of the bed during short periods of high or lov flow. The relations between bed-material size and bed elevation are discussed in the section, "Aggradation and degradation."

For many sets of bed-material samples, a measure of th a uniformity of the material was computed. This measure is called the geometric quartile deviation and is computed as $\sqrt{d_{75} / d_{25}}$, where $d_{75}$ and $d_{25}$ are the particle sizes at which either 75 or 25 percent of the bed material by weight is finer. Material that is perfectly uniform in size has a geometric quartile deviation of 1.00 , and material that has a wide range of size has a large geometric quartile deviation. Because only the middle 50 percent of the material is considered in computing

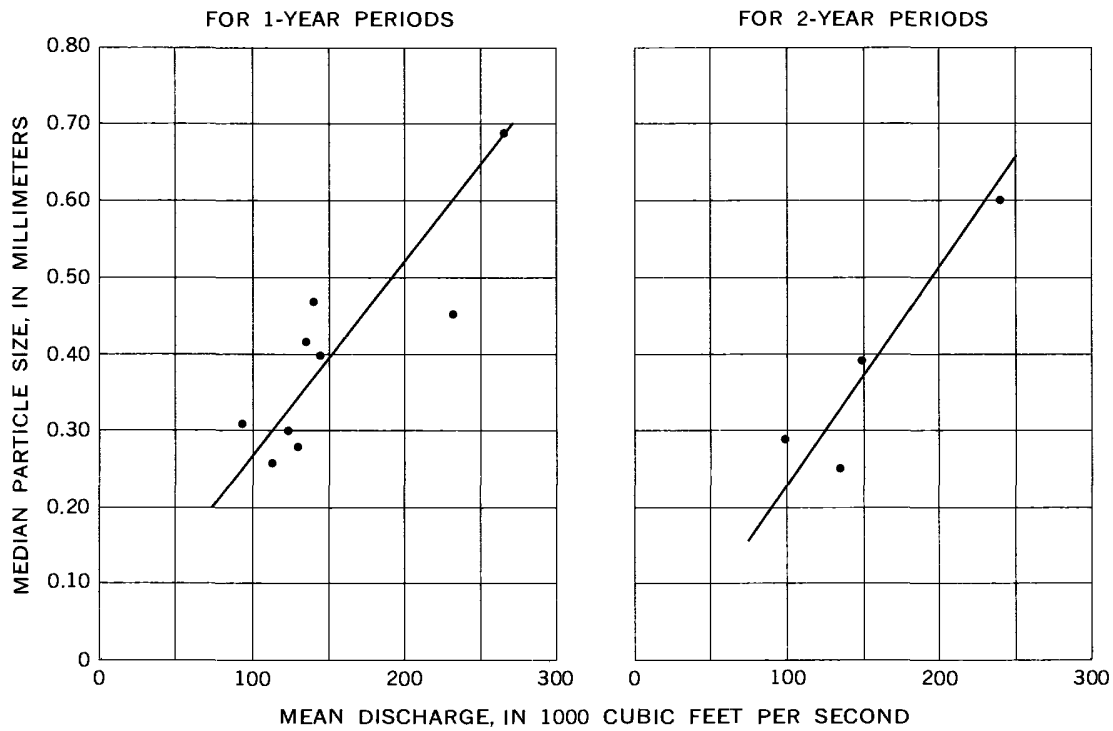

Figure 14.-Relation of bed-material size to discharge. 
this measure, however, values of 1.00 do not necessarily indicate that all the material is of uniform size. Also, two particle-size distributions that have the same geometric quartile deviation do not necessarily have the same extreme range of sizes. Because this measure is computed from the ratio of two sizes rather than from the difference, the geometric quartile deviations for different samples can be compared without making corrections for different average particle sizes.

The geometric quartile deviations for the bed material in the Mississippi River at St. Louis ranged from 1.1 to 2.5 and averaged 1.5. These values are intermediate in relation to those for some other streams for which bed material has been measured. Bed material of the Colorado River near Blythe, Calif., (median diameter about 0.33 $\mathrm{mm}$ ) and of the Rio Grande near Bernallilo, N. Mex., (median diameter about $0.30 \mathrm{~mm}$ ) has geometric quartile deviations of about 1.3 and 1.4, respectively. Bed material of the Kansas River at Wamego, Kans., (median diameter about $0.61 \mathrm{~mm}$ ) has a geometric quartile deviation of about 2.1 .

\section{AGGRADATION AND DEGRADATION}

Discharge measurements made about once each week, and sometimes more often, include data on depth and water-surface elevation that provide information on aggradation and degradation at the MacArthur Bridge. A study was made of the factors trat affect the streambed elevation. Mean bed elevations were computed for the part of the section between stations 275 and 1,800 , so trat a constant width could be used and so that the bed elevation would not be affected by the sloping banks. The range of mean bed elevations was from 355.1 to 364.4 feet above mean sea level during the period of sediment record.

The mean bed elevation is not significantly related to the instantaneous discharge, mean velocity, shear velocity, mean depth, nor suspended-sand concentration. The bed elevation and the median diameter of the bed material are fairly closely related (fig. 15). The relation indicates that the particle size is partly dependent on the depth of scour or that the depth of scour and the particle size are mutually dependent on the same causes. If the bed elevation is regarded as the dependent variable, it can be computed from the regression equation

where

$$
h_{h}=363.0-7.8 d_{50}
$$

$h_{b}$ is mean bed elevation, in feet above mean sea level $d_{50}$ is median diameter of bed material, in millimeters

The standard error of estimate for this equation is 0.91 foot. Multiple 
regressions with discharge, mean velocity, shear velocity, water-surface slope, and suspended-sand concentration did not result in significantly better relationships than $d_{50}$ alone.

Failure of the bed elevation to show a significant relation to instantaneous values except for $d_{50}$ suggests that the effect of such variables as discharge, mean velocity, water-surface slope, and susnended-sand concentration is cumulative over periods such as a week or a month. The cumulative effect of discharge on the bed elevation was studied by plotting the mean bed elevations for various periods against the discharges for various other periods that preceded or included the periods for which the mean bed elevations were determined. A relation was found between monthly mean bed elevation and the discharge for a 3-month period (fig. 16), but it changed from year to year.

\section{FLOW RESISTANCE AND SEDIMENT TRANSPTRTATION RESISTANCE TO FLOW}

Resistance to flow in sand-bed streams is governed mostly by the size and shape of the irregularities on the bed rather than by the

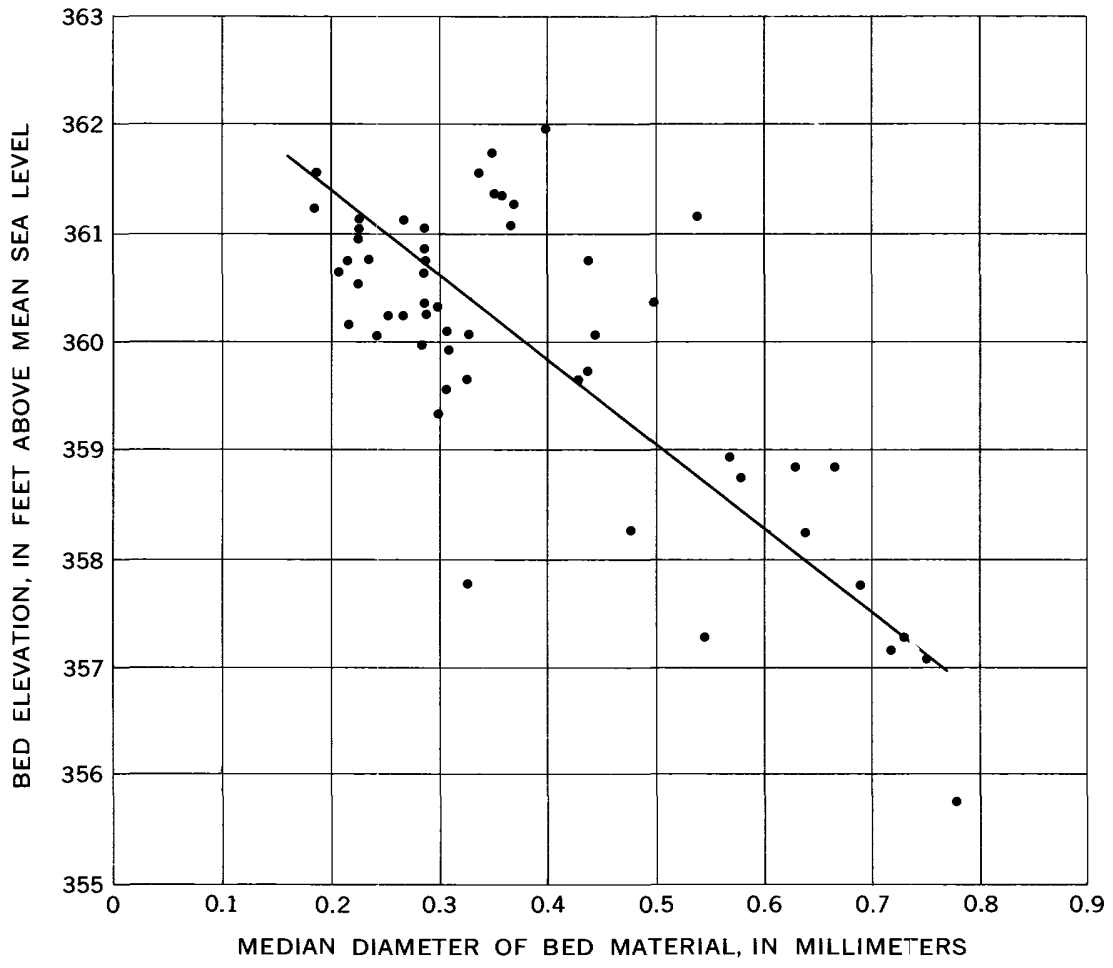

Figure 15.-Relation between bed elevation and particle size. 


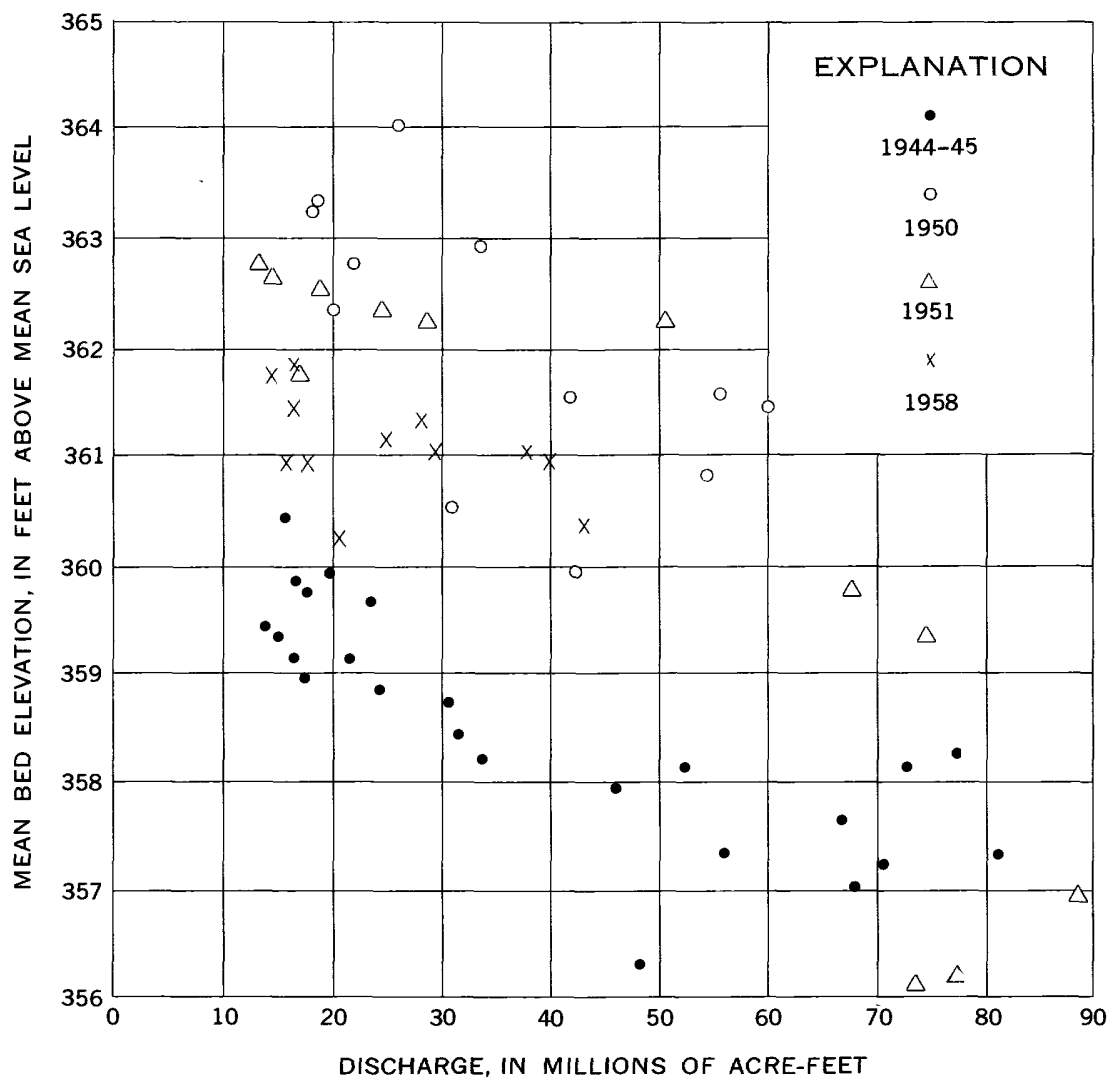

Figure 16.--Relation of monthly mean bed elevation to the discharge for 3-month periods. The mean bed elevation for each month has been plotted against the sum of the discharges for that month and the two preceding months.

grain size of the particles in the bed. Small rivers typically have dunes on the bed at low flow, but the dunes are washed out and the bed is fairly flat and regular at high flow. Measured by Manning's $n$, the resistance when dunes are on the bed is as much as twice the resistance when the bed is flat and regular. In shallow rivers the height of dunes is as much as half the depth of flow. The resistance to flow, however, is governed by the spacing of the dunes as well as by their height. One difficulty in the field study of resistance to flow in nonuniform cross sections is that the bed may be flat and regular in one part of the section but may have dunes in another part; thus, a resistance coefficient for the whole section will represent neither dunes nor a flat bed. Several methods of predicting the resistance to flow in alluvial channels have been proposed. Most of these methods have been based on experiments in laboratcry flumes and on a small amount of data from canals and natural streqms, most of them small. 
Among the few observations of bed configuration in large rivers are those of the lower Mississippi River in Louisiana (Carey and Keller, 1957). Carey and Keller concluded that the large-scale irregularities of the bed vary systematically with changes in discharge and constitute a major element of resistance to flow.

Although the data for the Mississippi River at St. Louis were not obtained primarily for the purpose of research, they can be used to supplement the data for flumes, small rivers, and the lower Mississippi River in the study of resistance to flow. Particularly useful are the data that permit comparison of resistance coefficients and the height and spacing of dunes with data for flumes and small rivers.

Pertinent measured and computed data from nearly concurrent measurements of discharge and sediment are shown in table 2. Hydraulic and sediment characteristics generally remain fairly constant for periods of a few days; therefore, data were considered to be concurrent if the time between the discharge measurement and the bed-material or suspended-sediment measurement was not more than 2 days.

The water-surface slopes in table 2 were determined from gage readings made at 8:00 a.m. each day at gages 4.4 miles upstream and 2.1 miles downstream from MacArthur Bridge. Readings at a gage near MacArthur Bridge were also used in determining the uniformity of slopes in the reaches upstream and downstream from the bridge. Gage readings were furnished by the U.S. Army Corps of Engineers, St. Louis District. During 1950-53, the slopes changed widely from time to time, but the slopes upstream and downstresm from the bridge were generally about the same at any given time. The slopes in the upstream reach tended to be slightly steeper then the slopes in the downstream reach. During 1954-59, the sloper were fairly constant, but those in the upstream reach were consistently steeper than those in the downstream reach; in 1956-57, the slopes upstream were about twice as steep as those downstream.

The widths shown in table 2 are the widths of the water surface excluding the two piers, each 27 feet wide. The hydraul: radius was computed by dividing the cross-sectional area, which excluded the area of the piers, by a wetted perimeter computed as the width plus twice the mean depth. The shear velocity was computed as $\sqrt{g R S}$, where $g$ is the acceleration due to gravity, $R$ is the hydraulic radius, and $S$ is the slope of the water surface for the 6.5-mile reach and is assumed to be equal to the energy gradient, for most conditions.

In July 1951 the flow was over the banks, and the width increased from about 1,780 to 2,800 feet. Inclusion of 1,000 feet of shallow, slow-moving, overbank flow in the computations would have produced highly nontypical values of mean depth and hydraulic radius. 
TaBLe 2.-Summary of hydraulic and

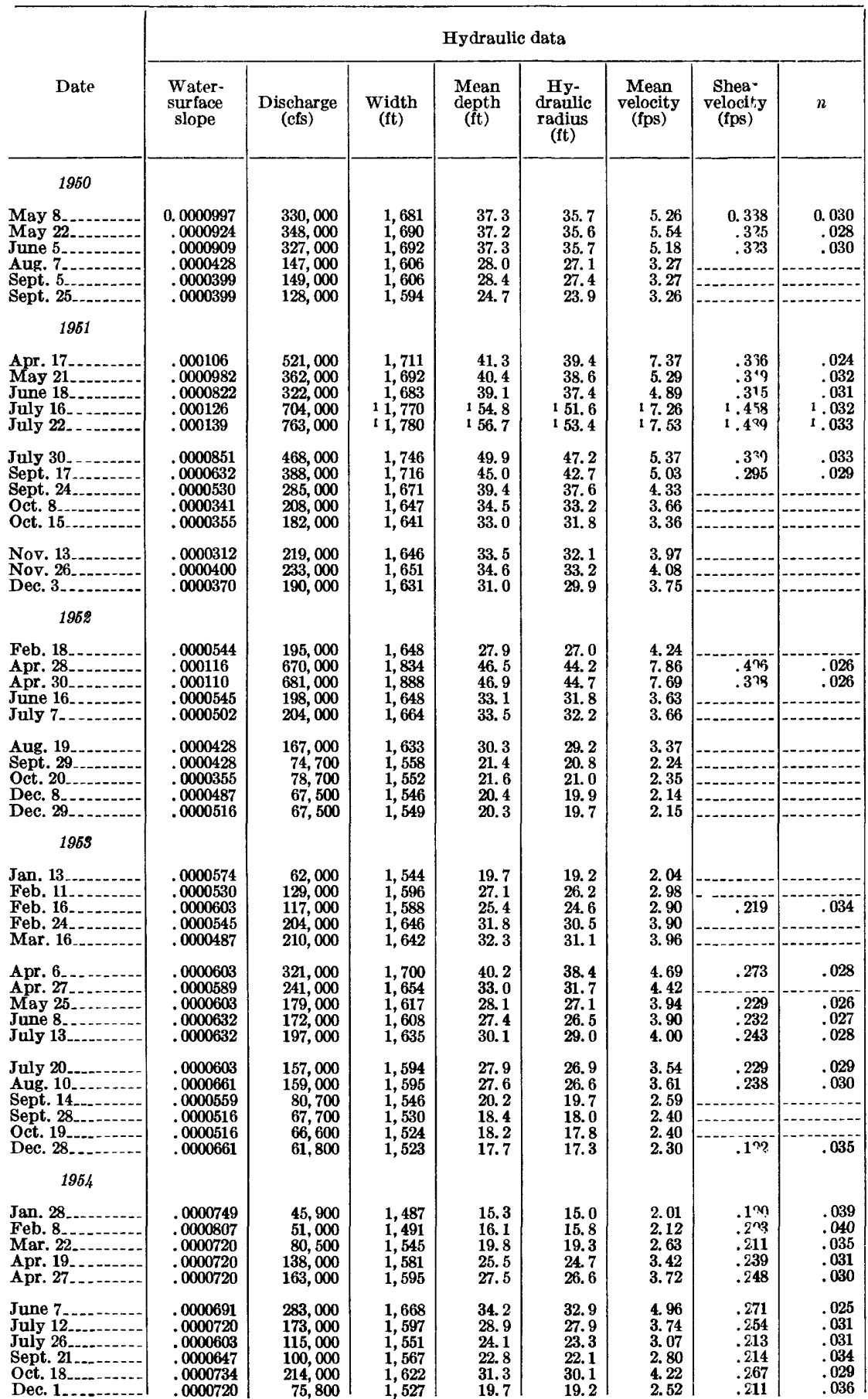

See footnotes at end of table. 
sediment data from concurrent measurements

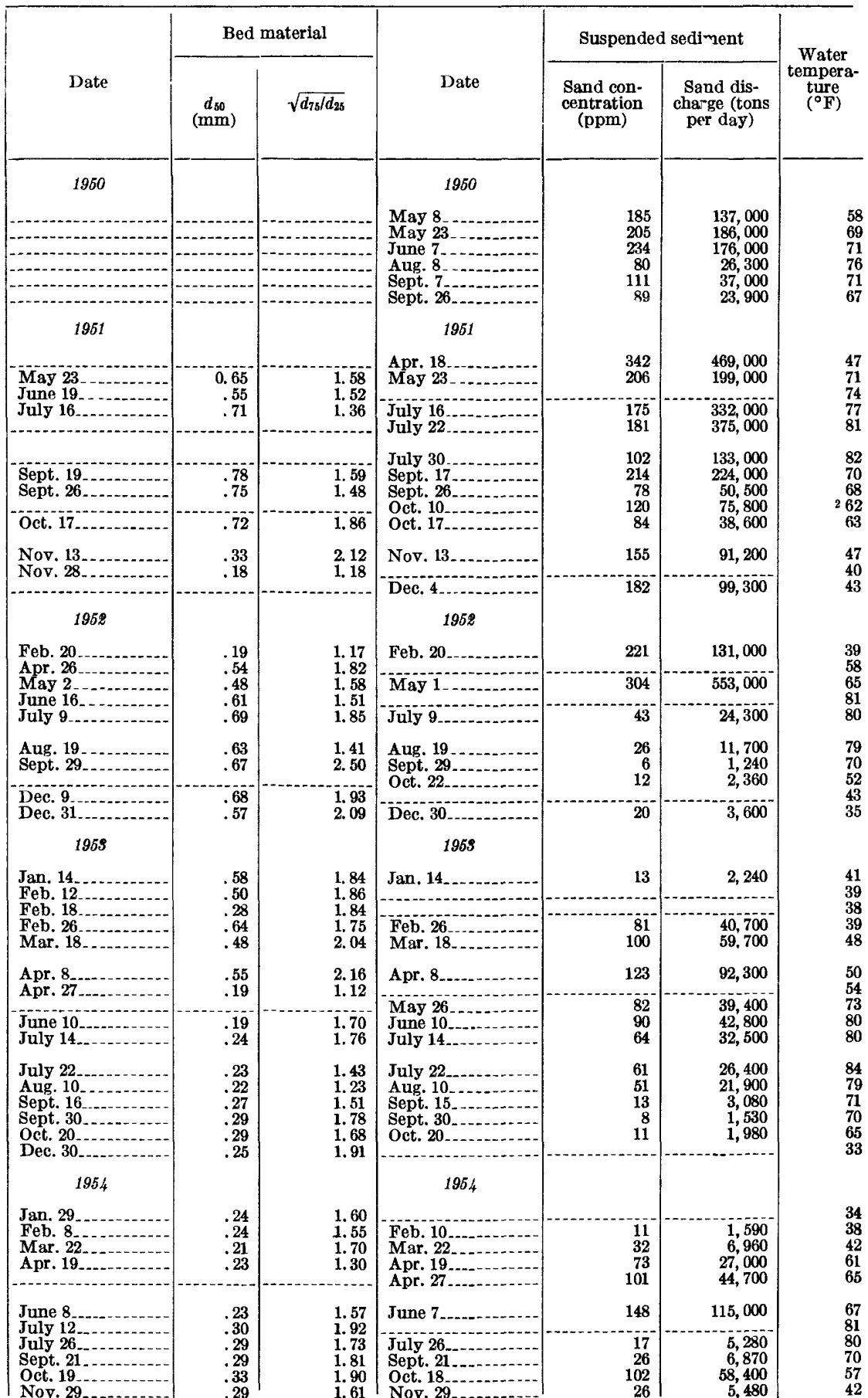


TABLE 2.-Summary of hydraulic and

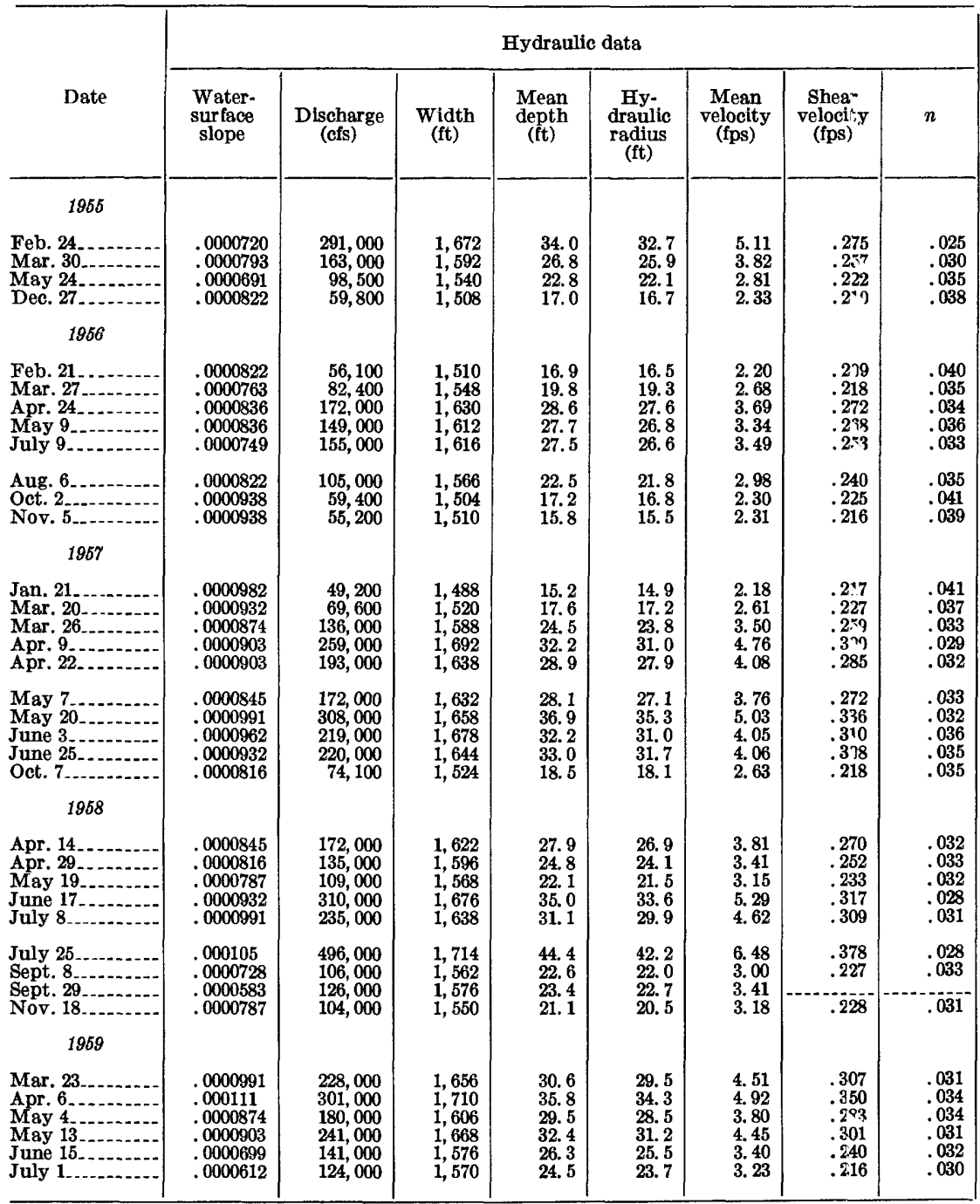

1 Excluding o verbank flow. 2 Estimated.

Therefore, these values were computed for only the part of the flow that was between the banks.

The variation of water-surface slope with river stage and with time indicates that the water-surface slope sometimes diverged radically from the energy gradient. The divergence between energy gradient and water-surface slope may have been caused by the pecul'ar conditions of the cross section about 3-4 miles downstream from MacArthur Bridge. During medium discharge, a narrow part of this section 
sediment data from concurrent measurements - Continued

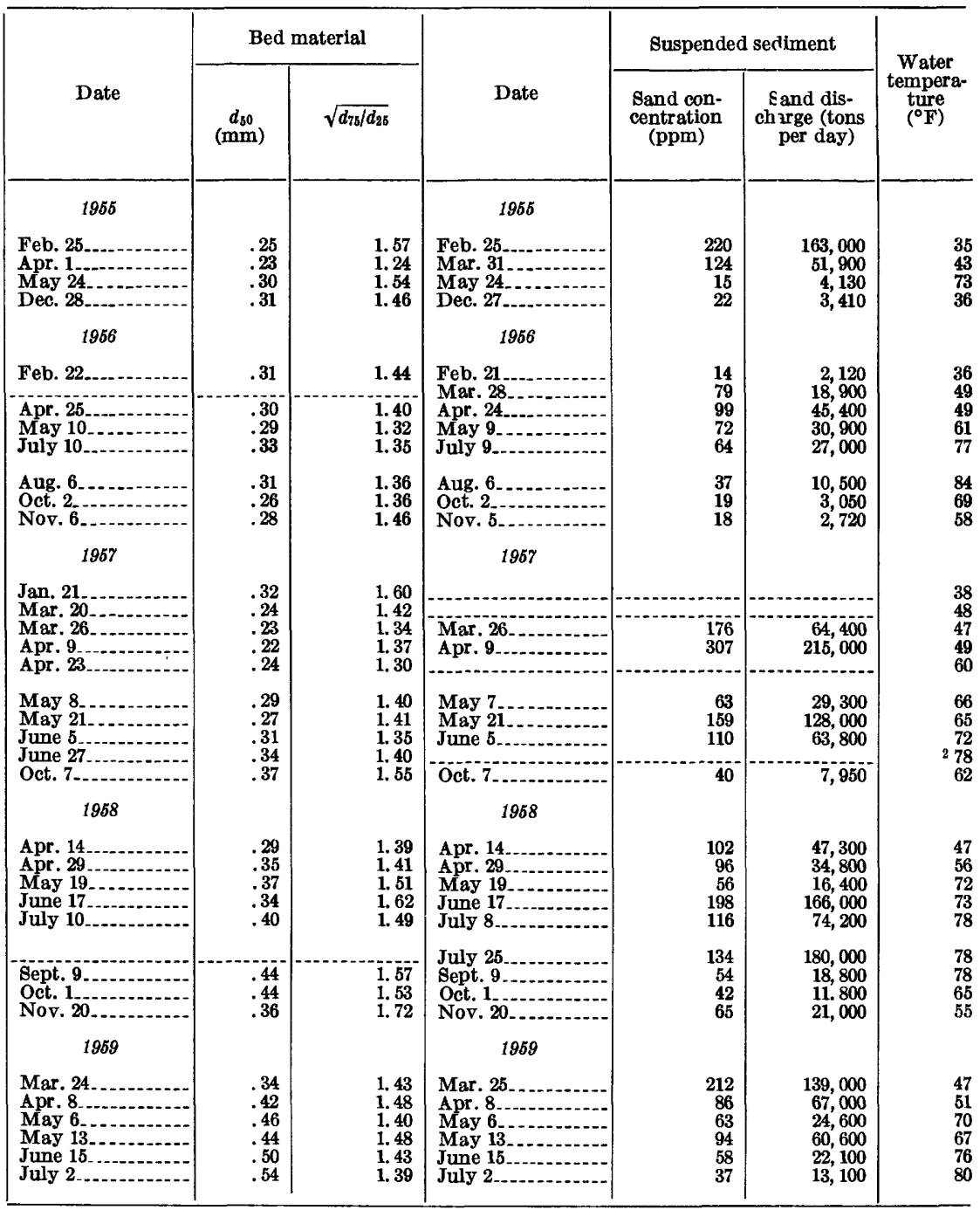

near the west bank is fairly deep and the rest of the section is wide and shallow. During very low discharge, the entire flow is near the west bank and a sand bar is exposed in the eastern part of the section. At high discharges, the flow can spread out over the wide section; and, as the discharge increases, the stage does not increase as much as it does at the narrower sections upstream. Therefore, the watersurface slope is greater at high discharges than at medium discharges. The water-surface slope was extremely low at some times of low and 
medium discharges, such as in August-November 1951. Normally, the relation of the elevations of the bed at this section and at sections upstream is such that the low and medium discharges pass witl out any noticeable effect on the water-surface slope. But the upstream sections, such as at MacArthur Bridge, were scoured out during the high flows of 1951 and 1952; and the deep part of the downstream section may have been partly filled in by sediment. After the high flows had passed, the elevation of the bed at the downstream section probably was higher than the elevation of the bed upstream; thus, the water-surface slope was less than normal. Water-surface slopes are normally high when discharges are high, regardless of scour or fill; however, water-surface slopes were extremely low only after upstream sections had been scoured and sediment probably lad been deposited in the deep part of the downstream section.

Data for computation of backwater curves had not been obtained when the water-surface slopes were extremely low, so sample computations were made to determine if the low water-surface slopes could reasonably have been caused by unusual nonuniformity of the channel. On November 13,1951 , the average slope in the 6.5 -mile reach was 0.0000312 , and the mean depth and mean velocity at $\mathrm{MrcArthur}$ Bridge were 33.5 feet and 3.97 feet per second, respectively. A backwater computation was made for the reach between MecArthur Bridge and the gage 2.1 miles downstream; gradually varied flow was assumed. Solution of the Bernoulli energy equation and the I. Tanning velocity equation by trial showed that a water-surface slope of 0.0000312 could have resulted if the mean velocity 2.1 miles downstream was 2.9 feet per second and if the average $n$ was 0.035 . Inspection of the water-surface slopes indicates that the normal slope is about 0.00009 . Because shear velocity and $n$ vary with the square root of the energy gradient, errors in the energy gradient will not cause very large errors in shear velocity nor in $n$. Therefore, the water-surface slope was assumed to be about equal to the energy gradient when it was not greatly different from 0.00009 ; but shear velocity and $n$ are not shown in table 2 unless the water-surface slope is greater than 0.00006 .

Data obtained with a sonic fathometer by the Corps of Engineers, St. Louis District, show that the normal dune height in the vicinity of MacArthur Bridge is from 2 to 8 feet and that the average dune length is about 250 feet. On April 30, 1952, when the resistance to flow as measured by Manning's $n$ was relatively low (0.026), dunes in the east side of the channel were from 2 to 7 feet high but $\varepsilon$,veraged about 900 feet in length; in the central and western parts of the channel, although the depths were not uniform, the changes were very gradual, and only a few isolated dunes were located. 
The range of variation of $n$ from 0.024 to 0.041 indicates that the bed at some times becomes fairly flat and regular. The fact that the minimum values of $n$ exceed the minimum for shallow streams, however, may indicate that the bed never becomes flat across the entire section but that dunes remain in parts of the section even when the discharge and mean velocity are very high.

The relations of $n$ to discharge, mean velocity, and shear velocity are shown in figure 17. The absence of a discontinuity in the relations of $n$ to discharge and mean velocity indicates that the fow resistance of dunes is variable and that, at high flows, part of tre section has dunes and part has a relatively flat bed. The facts that $n$ is not closely related to the shear velocity and that the range of shear velocities is not as great as the range of mean velocities are to be expected if the bed sometimes has dunes and sometimes is flat. If dunes are on the bed, the resistance to flow will be great and the velocity will be fairly low; thus, the flow will be fairly deep. If the discharge increases and the bed becomes flat, the resistance will decrease and the velocity will increase. Because of the increased velocity, the increased discharge can be carried at the same depth as before; and if the slopes are about the same, the shear velocities will be about the same. Therefore, the range of shear velocities will be small, and roughness coefficients will vary widely for a given shear velocity.

A method for computing mean velocity from Keulegen's equations was presented by Einstein (1950). In this method the shear velocity is divided into two parts: one part pertains to the shear transmitted to the boundary along the roughness of the grainy sand surface $\left(u_{*}{ }^{\prime}\right)$, and the other part pertains to the shear transmitted to the boundary in the form of normal pressures at the different sides of the bed irregularities such as ripples and dunes $\left(u_{*}{ }^{\prime \prime}\right)$. The accuracy of the method depends on the accuracy of the relation of the ratio $\bar{u} / u_{*}{ }^{\prime \prime}$ to the shear function $\Psi^{\prime}$ (Einstein, 1950, fig. 5).

For proper application of Einstein's method, the computations should be made for the average of several cross sections in a reach; however, data were available only for the section at MacArthur Bridge. Because the 6.5-mile reach for which the slopes vrere measured is rather uniform, the bridge section probably represents the reach about as well as the average of several cross sections would. Therefore, the functions $\bar{u} / u_{*}{ }^{\prime \prime}$ and $\Psi^{\prime}$ were computed from representative data at MacArthur Bridge, and their relation is shown in figure 18. The Mississippi River data confirm Einstein's relation very vrell except for low values of $\Psi^{\prime}$. The lack of agreement at low values of $\Psi^{\prime}$ can be attributed partly to the fact that at high flows the water-surface slope used in the computations for the Mississippi River is greater than the energy slope and partly to the fact that dunes exist in parts 

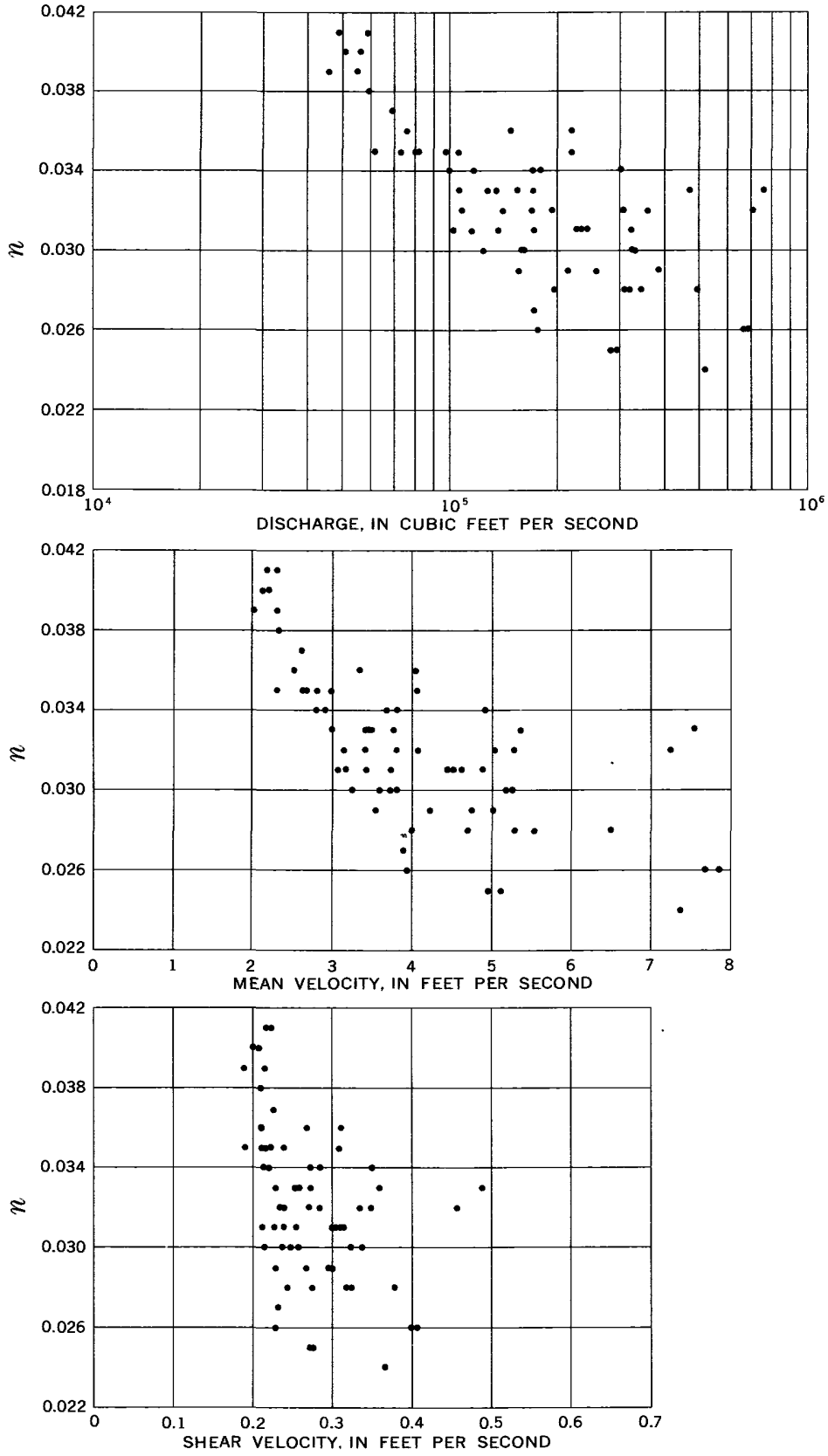

Figure 17.-Relation of Manning's $n$ to discharge, mean veloc'ty, and shear velocity. 


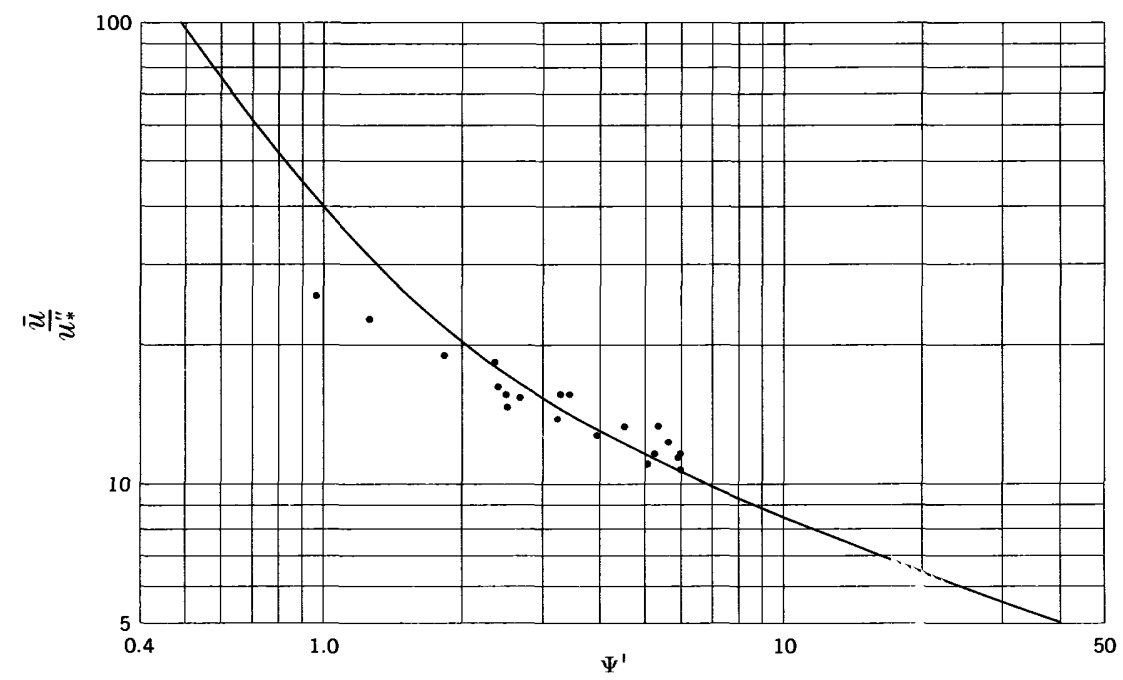

Figure 18.-Relation of $\bar{u} / u_{*}^{\prime \prime}$ to $\Psi^{\prime}$. Curve from Einstein (1950, fig. 5).

of the cross section even though much of the bed is fairly flat and regular.

When gage height is plotted against discharge of more than about $300,000 \mathrm{cfs}$ and consecutive measurements are connected, a loop generally appears in the curve; the gage height for a given discharge is generally lower when the discharge is increasing than when it is decreasing. The largest difference in gage heights for the same discharge for individual rises during the period of sediment record was in April and May 1951; the gage height was 23.8 feet for a discherge of 420,000 cfs when the discharge was increasing and 26.6 feet for the same discharge when the discharge was decreasing (fig. 19). During the same rise, at a gage height of 25.0 feet the increasing discharge was about $450,000 \mathrm{cfs}$ and the decreasing discharge was about 380,000 cfs. Possible conditions that could cause this kind of loop in the relation of gage height to discharge are (1) scour during increasing discharge and fill during decreasing discharge, (2) lower turbulence constant due to higher sediment concentrations during increasing discharge than during decreasing discharge, (3) less channel roughness during increasing discharge than during decreasing discharge, and (4) higher energy gradient during increasing discharge than during decreasing discharge.

Figure 19 shows that, for a given discharge, the mear bed elevation is consistently higher when the discharge is increasing than when it is decreasing. Therefore, scour and fill could not cause the loop in the relation of gage height to discharge. 

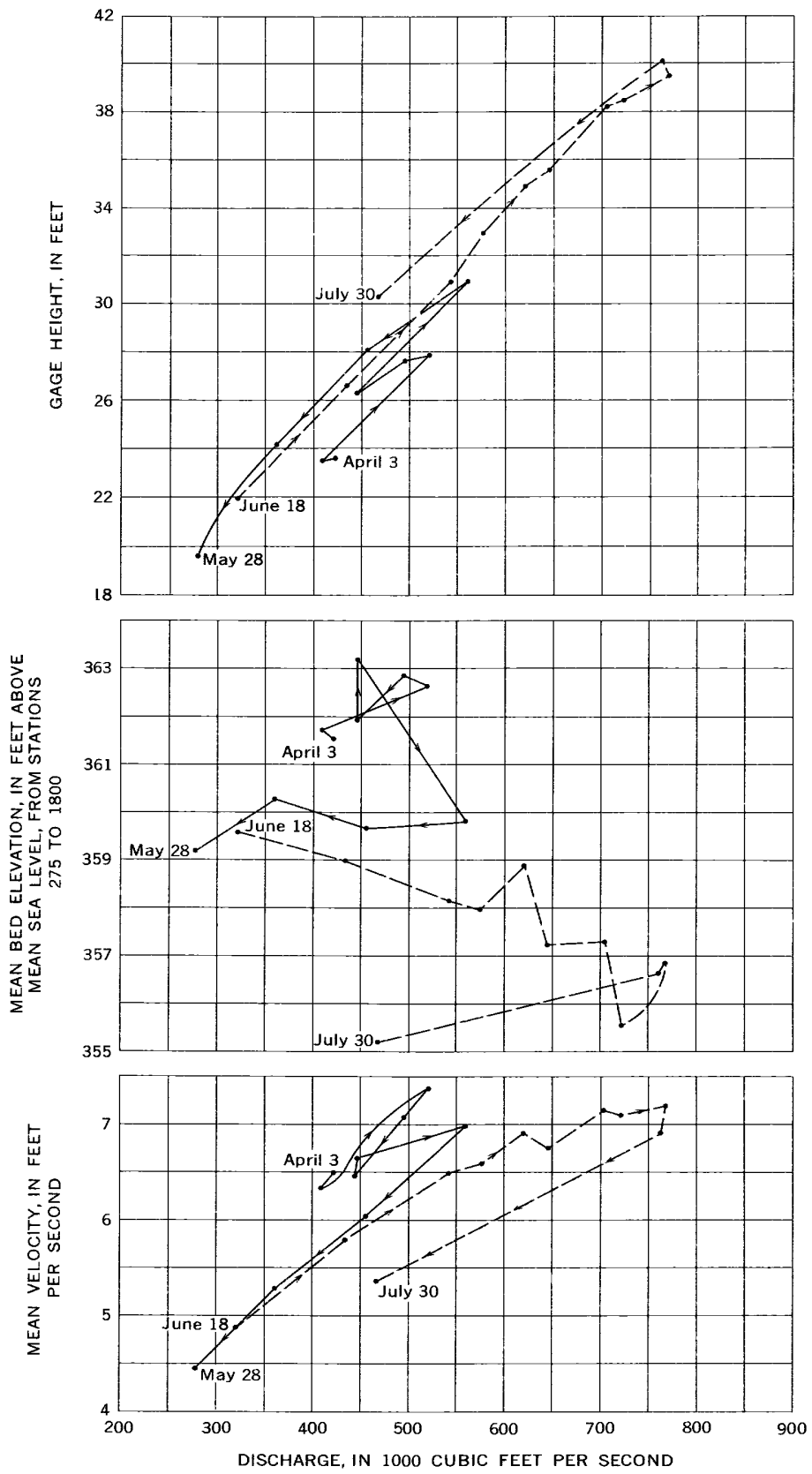

Figure 19.--Relation of gage height, bed elevation, and velocity to discharge during major rises in 1951. 
Graphs of mean velocity plotted aga inst discharge (fig. 19) show that, for a given discharge, the mean velocity is generally much higher for increasing discharge than it is for decreasing discharge. The velocity for decreasing discharge is low enough not only to counterbalance the scour of the bed but to cause a higher gage height. The lower velocity could be caused by higher turbulence constant, by greater channel roughness, by lower energy gradient due to changing discharge, by channel storage between the gage and the measuring section, or by return of overbank flow.

Sample computations were made to determine the change in turbulence constant that would be necessary to cause the observed change in mean velocity. Keulegan's equation for mean velocity in rough channels can be written as

where

$$
\frac{\bar{u}}{u_{*}}=6.25+\frac{2.3}{k} \log \frac{R}{k_{s}}
$$

$u_{*}$ is shear velocity and equals $\sqrt{g R S_{e}}$, in which $S_{e}$ is the energy gradient

$k$ is the Von Karman coefficient for turbulent exchange

$k_{s}$ is a linear measure of the bed roughness

Turbulence constants were computed for increasing and decreasing discharges of 420,000 cfs in April and May 1951. Because the purpose was to determine the change in turbulence constant alone that would cause the observed change in mean velocity, the energy gradient $S_{e}$ was assumed to be constant at 0.00011 , the bed roughness $k_{s}$ was assumed to be constant at 1.6 , and the constant 6.25 for clear water was assumed to be applicable for sediment-laden flow. For increasing discharge of $420,000 \mathrm{cfs}$ in April 1951, the mean ve'ocity was 6.5 feet per second and the hydraulic radius was 37 feet. Solution of Keulegan's equation gave the result $k=0.27$. For decreasing discharge of $420,000 \mathrm{cfs}$ in May 1951, the mean velocity was 5.8 feet per second and the hydraulic radius was 40 feet. Sclution of the equation gave the result $k=0.35$. Vanoni (1946) roported that $k$ decreased as suspended-sediment concentration incres sed when the discharge and boundary conditions remained constant. The decrease in $k$ was larger when the suspended sediment was of small particle size than when the suspended sediment was sand. Einstein and Chien (1955) showed a relation of $k$ to a parameter of suspendedsediment concentration and fall velocity. According to this relation, the sediment having high fall velocity (large size) would have a greater effect on $k$ than the sediment having low fall velocity (small size). The suspended-sediment concentration of all particle sizes at an increasing discharge of $420,000 \mathrm{cfs}$ in April 1951 was about twice as great as the concentration at a decreasing discharge of $420,000 \mathrm{cfs}$ in 
May 1951. The difference in concentration was mostly in the finer sizes. According to the relation of Einstein and Chien, the observed decrease in concentration would not be enough to increase $k$ from 0.27 to 0.35 . Further information on the change in $k$ is given in the section, "Vertical distributions of velocity and sediment concentration."

A sample computation was made to determine what changes in roughness with constant energy gradient would be necersary to cause the observed change in mean velocity. For simplicity, the Manning equation was used instead of the Keulegan equation. For a constant energy gradient, let $n_{i}$ be the Manning resistance factor during increasing discharge of $420,000 \mathrm{cfs}$ in April 1951, and let $n_{d}$ be the Manning resistance factor during decreasing discharge of $420,000 \mathrm{cfs}$ in May 1951.

Then

and

$$
6.5=\frac{1.49}{n_{i}} 37^{2 / 3} S_{e}^{1 / 2}
$$

Solving for $n_{i}$,

$$
5.8=\frac{1.49}{n_{d}} 40^{2 / 3} S_{\epsilon}^{1 / 2}
$$

$$
n_{i}=0.85 n_{d}
$$

Changes in resistance factor of 15 percent or more are conmon at St. Louis; therefore, change in roughness alone could account for the loop in the relation of gage height to discharge.

Corbett and others (1943) stated that when the discharge is changing with respect to time, the relation of gage height to discharge may be affected by an increase or a decrease of water-surface slope from that corresponding to steady-flow conditions, conversion of c'ischarge into or out of channel storage, or return of overbank flow. If any of these factors were to account for the loops, the effects would have to be large enough to balance the changes in cross-sectional aren due to the changes in bed elevation.

The effect of changes in slope due to changes in discharge was computed from an approximate equation given by Corlett and others (1943, p. 153, eq. 10):

in which

$$
\frac{Q_{c}}{Q_{m}}=\frac{\sqrt{S_{c}}}{\sqrt{S_{c}+(1 / U) d h / d t}}
$$

$Q_{c}$ is the discharge for a given gage height under conditions of constant discharge

$Q_{m}$ is the measured changing discharge for the same gage height

$S_{c}$ is the slope of the water surface under constant discharge conditions

$U$ is the velocity of the flood wave

$d h / d t$ is the rate of change of stage 
When the formula is written in terms of discharge $Q_{c} / Q_{m}$, the crosssectional area must be assumed to be constant for a given gage height. The cross section at MacArthur Bridge is subject to scour and fill; so the formula was rewritten in terms of mean velocity:

in which

$$
\frac{\bar{u}_{c}}{\bar{u}_{m}}=\frac{\sqrt{S_{c}}}{\sqrt{S_{c}+(1 / U) d h / d t}}
$$

$\bar{u}_{c}$ is mean velocity under conditions of constant discharge

$\bar{u}_{m}$ is measured mean velocity under conditions of changing discharge

To compute the maximum effect of changing discharge, the velocity of the flood wave $U$ was computed from the empirical form ula (Corbett and others, 1943, p. 155, eq. 14) $U=1.3 \bar{u}$.

During most discharge measurements, the rate of change in gage height was very low. The effect of change in discharge was computed for two discharge measurements having relatively high rates of change in gage height; for the discharge measurements of June 29 and July 30,1951 , the rates of change in gage height were +0.036 and -0.127 foot per hour, respectively. For these computations, the watersurface slope for constant high discharge was assumed to be 0.00010. The computed ratios $\bar{u}_{c} \bar{u}_{m}$ were 0.994 and 1.029 for June 29 and July 30, respectively. These results show that the effect of change in discharge was too small to account for the loop in the relation of gage height to discharge.

Because the discharge measurements were made 1.1 miles downstream from the recording gage, channel storage could have some effect on the stage-discharge relationship. The effect was computed by using the equation (Corbett and others, 1943, p. 156, eq. 16):

$$
Q_{m}-Q_{g}=b L C \frac{d h}{d t}
$$

in which

$Q_{m}$ is the measured discharge

$Q_{g}$ is the discharge at the gage

$L \quad$ is the length between the sections at which $Q_{m}$ and $Q_{g}$ are determined

$C$ is a constant relating the rate of change of stage $d h / d t$ to its equivalent effect in the reach

Because the reach is nearly uniform, the constant $C$ was taken as 1.00. The computed differences $Q_{m}-Q_{\mathrm{g}}$ were +100 and $-350 \mathrm{cfs}$ for June 29 and July 30, respectively. The results indicate that channel storage does not affect the stage-discharge relationship significantly. 
The return of overbank flow could not anunt for the loops, because the loops have been observed for siages for which the flow was within the banks at the gage and ai least 4 miles upstream and downstream.

The conclusions from the study of the loops in the relation of gage height to discharge are:

1. For a given discharge during an individual rise, the gage height is lower for increasing discharge than for decreasing discharge even though the bed elevation is higher.

2. Change in turbulence constant due to changing sediment concentration could not in itself account for the loops.

3. Change in roughness could in itself account for the loops.

4. Change in energy gradient due to changing discharge, channel storage between the gage and the measuring section, or return of overbank flow could not account for the loops.

5. A combination of changes in roughness due to changing configuration of the bed and changes in turbulence constant due to changing sediment concentration probably account for the loops.

\section{VERTICAL DISTRIBUTIONS OF VELOCITY AND SEDIJ NENT CONCENTRATION}

By B. R. Colby

The Mississippi River at St. Louis provides ample depths for studies of vertical distributions of velocity and sediment concentration. Because the depth effect is not thoroughly understood for some aspects of sediment transportation, relationships defined for shallow flows should not be arbitrarily assumed to apply to deep flows. Therefore, the available information for the Mississippi River at St. Louis, even though incomplete and perhaps in part inexact (such as for water-surface slopes), may define vertical distrit utions of velocity and sediment concentration sufficiently well to aid in understanding theoretical and empirical relations for the Mississippi River and other streams.

\section{VELOCITY}

A convenient measure of the vertical distribution of velocity at constant shear velocity is the turbulence constant $k$ in equations that were given by Keulegan (1938) and used by Einstein (1950) for point and mean velocities in about the forms

$$
\begin{aligned}
& u_{y}=2.30 \frac{u_{*}}{k} \log \left(30.2 x y / k_{s}\right) \\
& \bar{u}_{s}=2.30 \frac{u_{*}}{k} \log \left(12.27 x y_{0} / k_{s}\right)
\end{aligned}
$$


In these equations, .,

$u_{y}$ and $\bar{u}_{s}$ are, respectively, the time-averaged velocity at a point and the mean velocity at a station

$y$ is the distance above the streambed

$x$ is a parameter to cover the transition from hydraulically smooth to hydraulically rough boundaries

$y_{0}$ is the depth of flow

The equations were derived by Keulegan for clear-water flow and rigid channel boundaries. According to Einstein (1950, p. 8), the $d_{65}$ size of a sediment mixture is the representative size to use as a measure of the roughness of a bed of sediment of mixed particle sizes. If no bed nor bank roughness exists except that due to the stationary grains, Einstein reasoned that $d_{65}$ could be used in place of $k_{s}$ in the equations and, for no significant sediment movement, that $k$ should about equal 0.40 .

These velocity equations may require some modifications for flows over beds of shifting sediment. Vanoni (1946) and Einstein and Chien (1954) reported that $k$ became less than 0.40 for sediment-laden flows over relatively smooth beds. The apparent reason for the reduction of $k$ is a dampening of turbulence because of the sediment in the flows. Another modification is in the roughness $k_{s}$. If the streambed has ripples, bars, or dunes, $k_{s}$ is far greater than $d_{65}$ and presumably depends both on the heights of the dunes, or other major roughness, and on the spacing of the dunes. A large $k_{s}$ can seldom be evaluated directly from the bed configuration, partly because the bed configuration is usually not known completely and partly becaus? the spacing of the major elements of bed roughness has an uncertain effect on $k_{s}$.

Einstein (1950, p. 10) adjusted the shear velocity for flows over beds of shifting sediment and used an equation for mean velocity in about the form

$$
\bar{u}_{s}=2.30 \frac{u_{*}^{\prime}}{0.40} \log \left(12.27 x y_{0} / d_{65}\right)
$$

in which $u_{*}{ }^{\prime}$ is the shear velocity with respect to the grsin (the shear velocity that will give the correct mean velocity) and 0.40 is substituted for $k$. The ratio $u_{*}{ }^{\prime} / u_{*}$ is equivalent to the ratio of the actual mean velocity to the mean velocity for a clear-water flow over a stationary bed whose only roughness is due to the unshifting grains and can be represented, at least roughly, by $d_{65}$. Ratios of $u_{*}^{\prime} / u_{*}$ as low as those for the Mississippi River at St. Louis (tabJe 3) indicate, as did the other measure of roughness $n$, that the bed of the river generally has the major roughness that might be carsed by bars, ripples, or dunes. 
TABLE 3.-Ratios of shear velocity with respect to the grain to shea- velocity

\begin{tabular}{|c|c|c|}
\hline Date & $\mathbf{u}_{*}^{\prime} / \mathbf{u}_{*}$ & Discharge (cfs) \\
\hline Apr. 18, 1951 & 0.64 & 510,000 \\
\hline July 16 & .53 & 704,000 \\
\hline June 7,1954 & .55 & 283,000 \\
\hline Mar. 30,1955 & .45 & 163,000 \\
\hline Dec. 27. & .36 & 59,800 \\
\hline Feb. 21, 1956_...- & .34 & 56,100 \\
\hline (no & .42 & 172,000 \\
\hline May 9 & .42 & 149,000 \\
\hline July 9 & .43 & 155,000 \\
\hline May 13,1959 & .47 & 241,000 \\
\hline
\end{tabular}

Even though $k_{s}$ cannot be evaluated for the flows over the rough streambed at St. Louis, the vertical distribution should still depend on the ratio of shear velocity to $k$ if the equations of the Keulegan type apply for both point and mean velocities. That is if these equations apply, the difference in point velocities at a distance $10 y$ above the streambed and at a distance $y$ above the bed equals 2.30 $u_{*} / k$, no matter what $k_{s}$ may be. For major roughness spaced as widely as bars or dunes may be, the vertical distribution of velocity may be, however, a function of the location of a vertical with respect to a dune or bar as well as of $u_{*} / k$. In other words, as sayre and Albertson (1959, p. 57-62) found for widely spaced baffles and clearwater flow, the $k$ determined from the vertical distribution cf velocity may not be the same as the $k$ for the mean-velocity equation.

Some variation of $k$ with change of the observation station can be shown by information at crest and trough of dunes in the Middle Loup River at Dunning, Nebr. Two $k$ 's from vertical dis'ributions of velocity at the crest of a dune were 0.32 and 0.62 as comp red with $k$ 's of 0.11 and 0.19 for stations in a trough downstream from the crest.

Basic data are shown in table 4 for current-meter observations of the vertical distributions of velocity at St. Louis. The $k$ 's in table 5 were computed from the data in table 4 and from the velocities of routine discharge measurements. 
TABLE 4.-Vertical distributions of velocity

[Velocities are averages for about $40-60 \mathrm{sec}$. unless otherwise noted]

\begin{tabular}{c|c|c|}
\hline Time & \multicolumn{2}{|c|}{ Measuring point } \\
\cline { 2 - 3 } & $\begin{array}{c}\text { Distance } \\
\text { from bed (ft) }\end{array}$ & $\begin{array}{c}\text { Velocity } \\
\text { (fps) }\end{array}$ \\
\hline
\end{tabular}

MAR. 2, 1948

Station 400; totai depth, $38.2 \mathrm{ft}$

\begin{tabular}{|c|c|c|}
\hline (1) & $\begin{array}{r}1.5 \\
2.3 \\
3.8 \\
5.7 \\
7.6 \\
11.5 \\
15.3 \\
19.1 \\
22.9 \\
26.7 \\
30.6 \\
34.4 \\
37.2\end{array}$ & $\begin{array}{l}3.08 \\
3.45 \\
3.67 \\
4.19 \\
4.19 \\
4.99 \\
5.10 \\
5.23 \\
5.77 \\
6.09 \\
6.20 \\
6.45 \\
6.45\end{array}$ \\
\hline
\end{tabular}

Station 625; total depth, $41.0 \mathrm{ft}$

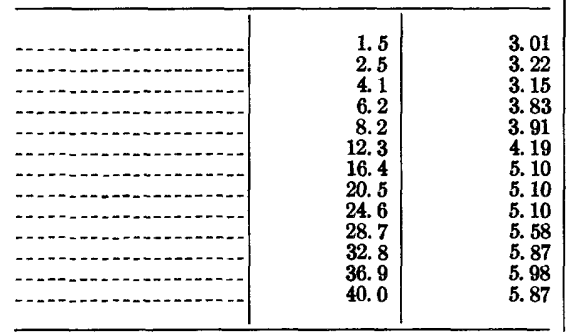

Station 850; totai depth, $41.2 \mathrm{ft}$

\begin{tabular}{|c|c|c|}
\hline (1) & $\begin{array}{r}1.5 \\
2.5 \\
4.1 \\
6.2 \\
8.2 \\
12.4 \\
16.5 \\
20.6 \\
24.7 \\
28.8 \\
33.0 \\
37.1 \\
40.2\end{array}$ & $\begin{array}{l}3.45 \\
3.26 \\
4.09 \\
4.19 \\
4.88 \\
5.31 \\
5.67 \\
5.98 \\
5.98 \\
6.45 \\
6.57 \\
6.85 \\
6.71\end{array}$ \\
\hline \multicolumn{3}{|c|}{ Station 1,200; total depth, $46.4 \mathrm{ft}$} \\
\hline (1) & $\begin{array}{r}1.5 \\
2.8 \\
4.6 \\
7.0 \\
9.3 \\
13.9 \\
18.6 \\
23.2 \\
27.8 \\
32.5 \\
37.2 \\
41.8 \\
45.4\end{array}$ & $\begin{array}{l}\text { 2. } 51 \\
\text { 3.15 } \\
\text { 3.15 } \\
\text { 3. 67 } \\
4.39 \\
4.99 \\
5.10 \\
5.49 \\
5.98 \\
5.87 \\
6.57 \\
6.85 \\
6.85\end{array}$ \\
\hline
\end{tabular}

\begin{tabular}{|c|c|c|c|} 
Time & Measuring point \\
\hline $\begin{array}{c}\text { Distance } \\
\text { from bed (ft) }\end{array}$ & $\begin{array}{c}\text { Velocity } \\
\text { (fps) }\end{array}$ \\
\hline
\end{tabular}

MAY 21, 1948

Station 400; total depth, $31.6 \mathrm{ft}$

\begin{tabular}{|c|c|c|}
\hline $12: 05$ p.m & $\begin{array}{r}1.6 \\
2.6 \\
3.6 \\
4.6 \\
5.6 \\
6.6 \\
7.6 \\
9.6 \\
11.6 \\
13.6 \\
15.6 \\
17.6 \\
19.6 \\
21.6 \\
23.6 \\
25.6 \\
27.6 \\
29.6\end{array}$ & $\begin{array}{l}2.44 \\
2.29 \\
2.61 \\
2.80 \\
2.80 \\
3.06 \\
\text { 3. } 21 \\
\text { 3. } 06 \\
3.21 \\
3.43 \\
3.43 \\
3.50 \\
3.98 \\
\text { 3. } 72 \\
3.80 \\
4.16 \\
4.16 \\
\text { 4. } 07\end{array}$ \\
\hline
\end{tabular}

Station 625; total depth, $33.0 \mathrm{ft}$

\begin{tabular}{|c|c|c|}
\hline 12:27 p.m & $\begin{array}{r}1.5 \\
2.0 \\
3.0 \\
4.0 \\
5.0 \\
7.0 \\
9.0 \\
11.0 \\
13.0 \\
15.0 \\
17.0 \\
19.0 \\
21.0 \\
23.0 \\
25.0 \\
27.0 \\
29.0 \\
31.0\end{array}$ & $\begin{array}{l}2.50 \\
2.55 \\
2.74 \\
3.06 \\
2.50 \\
2.74 \\
2.34 \\
2.86 \\
3.65 \\
3.65 \\
3.57 \\
4.07 \\
4.16 \\
4.16 \\
4.26 \\
4.75 \\
4.55 \\
4.55\end{array}$ \\
\hline
\end{tabular}

Station 850; total depth, $35.7 \mathrm{ft}$

\begin{tabular}{|c|c|c|}
\hline $12: 55$ p.m & $\begin{array}{r}1.5 \\
2.7 \\
3.7 \\
4.7 \\
5.7 \\
7.7 \\
9.7 \\
11.7 \\
13.7 \\
15.7 \\
17.7 \\
19.7 \\
21.7 \\
23.7 \\
25.7 \\
27.7 \\
29.7 \\
31.7 \\
33.7\end{array}$ & $\begin{array}{l}\text { 2. } 39 \\
2.92 \\
\text { 3. } 06 \\
\text { 3. } 21 \\
\text { 3. } 13 \\
\text { 3. 37 } \\
\text { 3. } 80 \\
\text { 3. } 65 \\
4.16 \\
\text { 3. } 72 \\
\text { 3. } 84 \\
4.07 \\
\text { 4. } 16 \\
4.37 \\
4.16 \\
4.46 \\
4.37 \\
4.55 \\
4.65\end{array}$ \\
\hline
\end{tabular}


FLUVIAL SEDIMENT, MISSISSIPPI RIVER, ST. LOUIS

TABLE 4.-Vertical distributions of velocity-Continued

\begin{tabular}{c|c|c|}
\hline \multirow{2}{*}{ Time } & \multicolumn{2}{|c|}{ Measuring point } \\
\cline { 2 - 3 } & $\begin{array}{c}\text { Distance } \\
\text { from bed (ft) }\end{array}$ & $\begin{array}{c}\text { Velocity } \\
\text { (fps) }\end{array}$ \\
\hline
\end{tabular}

MAY 21, 1948-Continued

Station 1,050; total depth, $34.3 \mathrm{ft}$

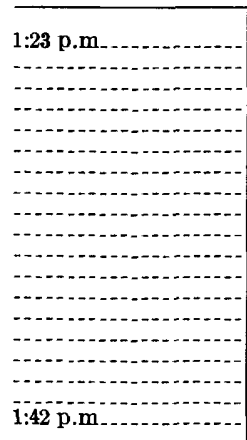

\begin{tabular}{r|}
0.5 \\
1.3 \\
2.3 \\
3.3 \\
4.3 \\
6.3 \\
8.3 \\
10.3 \\
12.3 \\
14.3 \\
16.3 \\
18.3 \\
20.3 \\
22.3 \\
24.3 \\
26.3 \\
28.3 \\
30.3 \\
32.3
\end{tabular}

2.05

2.92

2.63

3. 21

3. 37

3. 37 . 65

3. 65
3. 89

4. 37

4.26
4.26
4.07

4. 07

4. 37

4. 37

4.37
4.37

4.55

4. 46

\section{Station 1,200; total depth, $38.3 \mathrm{ft}$}

\begin{tabular}{|c|c|c|}
\hline $1: 48$ p.m & $\begin{array}{r}1.5 \\
2 . \mathbf{3} \\
\mathbf{3 . 3} \\
4 . \mathbf{3} \\
\mathbf{5 . 3} \\
6 . \mathbf{3} \\
\mathbf{8} . \mathbf{3} \\
10 . \mathbf{3} \\
12 . \mathbf{3} \\
14 . \mathbf{3} \\
16 . \mathbf{3} \\
18 . \mathbf{3} \\
20 . \mathbf{3} \\
22 . \mathbf{3} \\
24 . \mathbf{3} \\
26 . \mathbf{3} \\
28 . \mathbf{3} \\
30 . \mathbf{3} \\
\mathbf{3 2 . 3} \\
\mathbf{3 4} . \mathbf{3} \\
\mathbf{3 6 . 3}\end{array}$ & $\begin{array}{l}2.55 \\
2.61 \\
2.58 \\
2.92 \\
\text { 3. 50 } \\
3.21 \\
\text { 3. } 72 \\
\text { 3. } 98 \\
4.20 \\
4.07 \\
4.26 \\
4.07 \\
4.16 \\
4.07 \\
3.98 \\
4.65 \\
4.55 \\
4.16 \\
4.85 \\
4.75 \\
4.85\end{array}$ \\
\hline \multicolumn{3}{|c|}{ Station 1,400; total depth, $42.0 \mathrm{ft}$} \\
\hline 2:15 p.m. & $\begin{array}{l}1.5 \\
2.0 \\
3.0 \\
4.0 \\
5.0 \\
6.0 \\
8.0 \\
10.0 \\
12.0 \\
14.0 \\
16.0 \\
18.0 \\
20.0 \\
22.0 \\
24.0 \\
26.0 \\
28.0 \\
30.0 \\
32.0 \\
34.0 \\
36.0 \\
38.0 \\
40.0\end{array}$ & $\begin{array}{l}2.55 \\
3.29 \\
2.92 \\
2.86 \\
2.99 \\
3.06 \\
2.86 \\
2.92 \\
3.21 \\
3.21 \\
4.16 \\
4.85 \\
4.96 \\
4.96 \\
4.55 \\
4.37 \\
4.96 \\
5.32 \\
5.32 \\
5.45 \\
5.55 \\
5.45 \\
5.45\end{array}$ \\
\hline
\end{tabular}

\begin{tabular}{|c|c|c|}
\hline \multirow[b]{2}{*}{ Time } & \multicolumn{2}{|c|}{ Measuring point } \\
\hline & $\begin{array}{c}\text { Distance } \\
\text { from bed (ft) }\end{array}$ & $\begin{array}{l}\text { Velocity } \\
\text { (fps) }\end{array}$ \\
\hline $\begin{array}{r}\text { MAY 21, } \\
\text { Station 1,500 }\end{array}$ & $\begin{array}{l}1948 \text {-Continu } \\
\text { total depth, }\end{array}$ & \\
\hline $\begin{array}{l}10: 40 \text { a.m } \\
\\
\end{array}$ & $\begin{array}{r}1.5 \\
2.2 \\
3.2 \\
4.2 \\
5.2 \\
6.2 \\
8.2 \\
10.2 \\
12.2 \\
14.2 \\
16.2 \\
18.2 \\
20.2 \\
22.2 \\
24.2 \\
26.2 \\
28.2 \\
30.2 \\
32.2 \\
34.2 \\
36.2\end{array}$ & 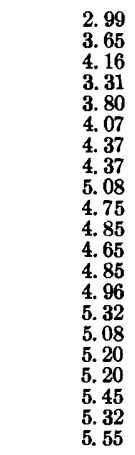 \\
\hline
\end{tabular}

Station 1,650; total depth, $40.5 \mathrm{ft}$

\begin{tabular}{|c|c|c|}
\hline 10:00 a.m & $\begin{array}{r}1.5 \\
2.5 \\
3.5 \\
4.5 \\
6.5 \\
8.5 \\
10.5 \\
12.5 \\
14.5 \\
16.5 \\
18.5 \\
20.5 \\
22.5 \\
24.5 \\
26.5 \\
28.5 \\
30.5 \\
32.5 \\
34.5 \\
36.5 \\
38.5\end{array}$ & $\begin{array}{l}\text { 3. } 72 \\
\text { 3. } 80 \\
\text { 3.57 } \\
\text { 3. } 98 \\
4.37 \\
4.37 \\
4.46 \\
4.20 \\
\text { 4. 37 } \\
4.46 \\
4.28 \\
4.37 \\
4.55 \\
4.96 \\
4.75 \\
4.75 \\
4.55 \\
5.08 \\
5.45 \\
5.08 \\
4.96\end{array}$ \\
\hline
\end{tabular}

MAR. 17, 1952

Station 500; total depth, $40.1 \mathrm{ft}$

\begin{tabular}{l|r|r}
\hline $9: 20$ a.m & 1.5 & 4.86 \\
\hline & 4.0 & 5.71 \\
\hline & 8.0 & 6.62 \\
\hline 9.35 a.m. & 11.9 & 7.19 \\
\hline & 19.5 & 7.35 \\
& 23.3 & 7.69 \\
& 27.0 & 8.07 \\
& 30.9 & 8.07 \\
& 34.8 & 8.27
\end{tabular}

Station 900; total depth, $3 ? .8 \mathrm{ft}$

\begin{tabular}{r|r|r}
\hline 10.50 a.m & 1.5 & 6.37 \\
& 3.5 & 6.90 \\
& 6.6 & 7.35 \\
& 9.8 & 7.88 \\
& 13.0 & 7.88 \\
\hline
\end{tabular}


TABLE 4.-Vertical distributions of velocity-Continued

\begin{tabular}{|c|c|c|c|}
\hline \multirow{2}{*}{ Time } & \multicolumn{3}{|c|}{ Measuring point } \\
\hline & $\begin{array}{c}\text { Distance } \\
\text { from bed (ft) }\end{array}$ & \multicolumn{2}{|r|}{$\begin{array}{l}\text { Velocity } \\
\text { (fps) }\end{array}$} \\
\hline \multicolumn{4}{|c|}{$\begin{array}{c}\text { MARCH } 17,1952-\text { Continued } \\
\text { Station 900; total depth, } 32.8-\text { Continued }\end{array}$} \\
\hline $11: 05$ a.m- & $\begin{array}{l}19.4 \\
22.1 \\
25.6 \\
28.6\end{array}$ & & $\begin{array}{l}\text { 8. } 65 \\
8.82 \\
9.19 \\
9.19\end{array}$ \\
\hline \multicolumn{4}{|c|}{ Station 1,275; total depth, $48.1 \mathrm{ft}$} \\
\hline 1:30 p.m & $\begin{array}{r}1.5 \\
3.4 \\
8.3 \\
13.3 \\
18.3 \\
23.1 \\
28.0 \\
32.8 \\
37.7 \\
42.3\end{array}$ & & $\begin{array}{l}4.31 \\
5.14 \\
5.52 \\
6.37 \\
6.97 \\
7.55 \\
7.60 \\
7.78 \\
7.88 \\
8.17\end{array}$ \\
\hline \multicolumn{4}{|c|}{ Station 1,600 ; total depth, $44.1 \mathrm{ft}$} \\
\hline 2:00 p.m & $\begin{array}{r}1.5 \\
4.7 \\
9.1 \\
13.4 \\
17.7 \\
21.8 \\
26.1 \\
30.4 \\
34.5 \\
38.7\end{array}$ & & $\begin{array}{l}5.52 \\
6.13 \\
6.75 \\
7.19 \\
7.44 \\
7.69 \\
8.07 \\
7.78 \\
7.78 \\
7.88\end{array}$ \\
\hline \multicolumn{4}{|c|}{$\begin{array}{c}\text { APR. 30, } 1952 \\
\text { Station } 750 ; \text { total depth, } 52.1 \mathrm{ft}\end{array}$} \\
\hline $\begin{array}{l}-1 \\
-1\end{array}$ & $\begin{array}{r}5.1 \\
10.3 \\
15.6 \\
20.8 \\
26.0 \\
31.2 \\
36.4 \\
41.7 \\
46.9\end{array}$ & & $\begin{array}{l}5.42 \\
6.55 \\
7.48 \\
7.80 \\
8.34 \\
8.70 \\
8.73 \\
9.12 \\
9.35\end{array}$ \\
\hline Station 475 ; & $\begin{array}{l}\text { NE } 7,1954 \\
\text { total depth, }\end{array}$ & 37.5 & ft \\
\hline $11: 42$ a.m. & $\begin{array}{r}1.5 \\
3.7 \\
7.5 \\
15.0 \\
22.5 \\
33.7\end{array}$ & & $\begin{array}{l}\text { 3. } 16 \\
\text { 3. } 76 \\
\text { 3. } 93 \\
\text { 4. } 41 \\
\text { 4. } 70 \\
\text { 5. } 51\end{array}$ \\
\hline \multicolumn{4}{|c|}{ Station S00; total depth, $34.3 \mathrm{ft}$} \\
\hline $10: 46$ a.m. & $\begin{array}{r}1.5 \\
3.4 \\
6.8 \\
13.7 \\
20.5 \\
30.9\end{array}$ & & $\begin{array}{l}4.41 \\
5.13 \\
4.90 \\
6.01 \\
6.24 \\
6.36\end{array}$ \\
\hline
\end{tabular}

\begin{tabular}{|c|c|c|}
\hline \multirow{2}{*}{ Time } & \multicolumn{2}{|c|}{ Me } \\
\hline & $\begin{array}{c}\text { Distance } \\
\text { from bed (ft) }\end{array}$ & $\begin{array}{l}\text { Velocity } \\
\text { (fps) }\end{array}$ \\
\hline \multicolumn{3}{|c|}{$\begin{array}{l}\text { JUNE } 7,1954-\text { Continued } \\
\text { Station 1,300; total depth, } 44.6 \mathrm{ft}\end{array}$} \\
\hline 10:11 a.m. & $\begin{array}{r}1.5 \\
4.5 \\
8.9 \\
17.8 \\
26.7 \\
40.1\end{array}$ & $\begin{array}{l}\text { 3. } 40 \\
\text { 4. 31 } \\
\text { 4. } 41 \\
6.01 \\
6.01 \\
6.36\end{array}$ \\
\hline
\end{tabular}

Station 1,600; total de ᄀth, $42.6 \mathrm{ft}$

\begin{tabular}{l|r|r}
\hline $9: 13$ a.m & 1.5 & 3.68 \\
\hline $9: 25$ a.m & 4.3 & 4.01 \\
& 8.4 & 4.60 \\
& 17.0 & 4.70 \\
\hline
\end{tabular}

AUG. 10, 195 !

Station 1,000; total derth, $23.1 \mathrm{ft}$

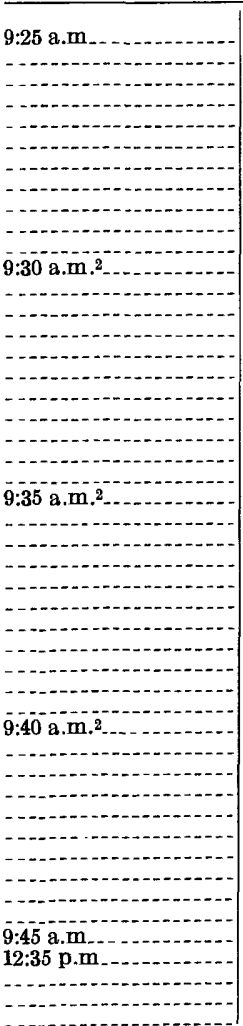

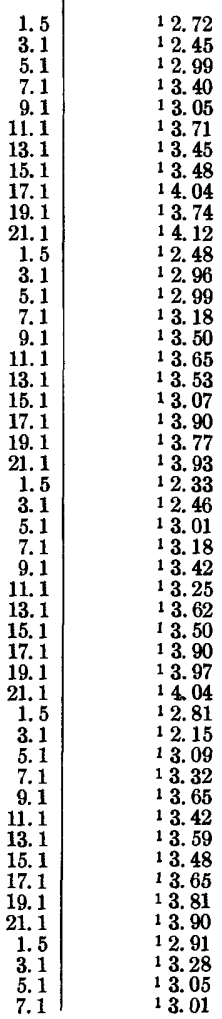

See footnotes at end of table, p. 54 . 
FLUVIAL SEDIMENT, MISSISSIPPI RIVER, ST. LOUIE

TABLE 4.-Vertical distributions of velocity-Continued

\begin{tabular}{|c|c|c|}
\hline \multirow{2}{*}{ Time } & \multicolumn{2}{|c|}{ Measuring point } \\
\hline & $\begin{array}{c}\text { Distance } \\
\text { from bed (ft) }\end{array}$ & $\begin{array}{l}\text { Velocity } \\
\text { (fps) }\end{array}$ \\
\hline \multicolumn{3}{|c|}{ AUG. 10, 1954-Continued } \\
\hline \multicolumn{3}{|c|}{ Station 1,000; total depth, $23.1 \mathrm{ft}$-Continued } \\
\hline & 9.1 & ${ }^{1} 3.50$ \\
\hline & 11.1 & 13.30 \\
\hline & 13.1 & $\begin{array}{l}13.42 \\
13.87\end{array}$ \\
\hline & 17.1 & 13.74 \\
\hline & 19.1 & $\begin{array}{l}14.12 \\
14.12\end{array}$ \\
\hline $12: 39$ p.m. & $\begin{array}{r}1.1 \\
1.5\end{array}$ & $\begin{array}{l}12.161 \\
12.61\end{array}$ \\
\hline & $\begin{array}{l}3.1 \\
5.1\end{array}$ & $\begin{array}{l}12.65 \\
13.45\end{array}$ \\
\hline & 7.1 & 12.95 \\
\hline & 9.1 & 1.3.32 \\
\hline & 13.1 & 3. 18 \\
\hline$\ldots$ & 15.1 & 1. 3.81 \\
\hline & $\begin{array}{l}17.1 \\
19.1\end{array}$ & $\begin{array}{l}13.81 \\
13.71\end{array}$ \\
\hline & 21.1 & 14.08 \\
\hline $12: 43$ p.m.2. & 1.5 & 12.68 \\
\hline & 3.1 & 13.01 \\
\hline$-\cdots$ & 5.1 & 13.07 \\
\hline-- & $\begin{array}{l}7.1 \\
9.1\end{array}$ & 13.05 \\
\hline$\cdots$ & $\begin{array}{r}9.1 \\
11.1\end{array}$ & $\begin{array}{l}13.40 \\
13.53\end{array}$ \\
\hline - n & 13.1 & i3.77 \\
\hline$-\ldots$ & $15 . \overline{1}$ & 13.68 \\
\hline$-\ldots \ldots$ & 17.1 & 13. 62 \\
\hline-- & 19.1 & 13.77 \\
\hline $12: 47$ p.m. & $\begin{array}{r}1.1 \\
1.5\end{array}$ & $\begin{array}{l}12.81 \\
2.50\end{array}$ \\
\hline - & 3.1 & i 3.05 \\
\hline$-\ldots$ & 5.1 & 13.12 \\
\hline - & $\begin{array}{l}7.1 \\
9.1\end{array}$ & 13. 20 \\
\hline - non & $\begin{array}{r}9.1 \\
11.1\end{array}$ & $\begin{array}{l}3.39 \\
13.05\end{array}$ \\
\hline - & 13. 1 & 13.71 \\
\hline ( & 15. 1 & 13.59 \\
\hline (n) & $\begin{array}{l}17.1 \\
19.1\end{array}$ & $\begin{array}{l}13.81 \\
14.04\end{array}$ \\
\hline $12: 50 \mathrm{p} . \mathrm{m}$ & 21.1 & $\begin{array}{l}14.04 \\
13.90\end{array}$ \\
\hline
\end{tabular}

A UG. 27, 1954

Station 1,000; total depth, 24.0 ft

\begin{tabular}{|c|c|c|}
\hline $8: 40$ a.m. & $\begin{array}{r}1.5 \\
4.0 \\
6.0 \\
10.0 \\
14.0 \\
18.0 \\
22.0 \\
1.5 \\
4.0 \\
6.0 \\
10.0 \\
14.0 \\
18.0 \\
22.0 \\
1.5 \\
4.0 \\
6.0 \\
10.0 \\
14.0 \\
18.0 \\
22.0 \\
1.5 \\
4.0 \\
6.0 \\
10.0 \\
14.0 \\
18.0 \\
22.0\end{array}$ & 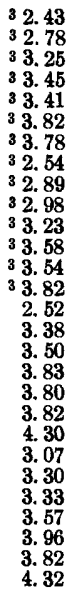 \\
\hline
\end{tabular}

See footnotes at end of table, p. 54 .

\begin{tabular}{|c|c|c|}
\hline \multirow{2}{*}{ 'Time } & \multicolumn{2}{|c|}{ Measuring point } \\
\hline & $\begin{array}{c}\text { Distance } \\
\text { from bed (ft) }\end{array}$ & $\begin{array}{l}\text { Velocity } \\
\text { (fps) }\end{array}$ \\
\hline \multicolumn{3}{|c|}{ MAR. 31, 1955} \\
\hline \multicolumn{3}{|c|}{ Station 500; total depth, $24.7 \mathrm{ft}$} \\
\hline $10: 45 \mathrm{a} . \mathrm{m}$ & 1.5 & 2.90 \\
\hline . & 3.5 & 3.2 \\
\hline-1 & $\begin{array}{l}4.0 \\
6.5\end{array}$ & $\begin{array}{l}5.42 \\
3.70\end{array}$ \\
\hline- & $\begin{array}{r}8.5 \\
10.6\end{array}$ & $\begin{array}{l}3.95 \\
3.95\end{array}$ \\
\hline 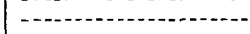 & 13.6 & 3. 7 \\
\hline- & $\begin{array}{l}10.0 \\
19.6\end{array}$ & $\begin{array}{l}4.0 \\
4.3\end{array}$ \\
\hline $10: 55 \mathrm{a} . \mathrm{m}$ & 22.7 & 4.44 \\
\hline $12: 30$ p.m & 1.5 & 2.78 \\
\hline 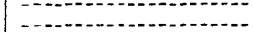 & $\begin{array}{l}0.0 \\
4.5\end{array}$ & 3.49 \\
\hline$-\ldots . . .-$ & 6.5 & 3. 63 \\
\hline$-\cdots$ & $\begin{array}{r}8.6 \\
10.6\end{array}$ & $\begin{array}{l}3.86 \\
3.63\end{array}$ \\
\hline$\ldots . .$. & 13. 6 & 4.18 \\
\hline (n......... & 16.6 & 4.18 \\
\hline $12: 35 \mathrm{p.m}$ & 22.7 & 4.50 \\
\hline
\end{tabular}

Station 925; total depth, $29.1 \mathrm{ft}$

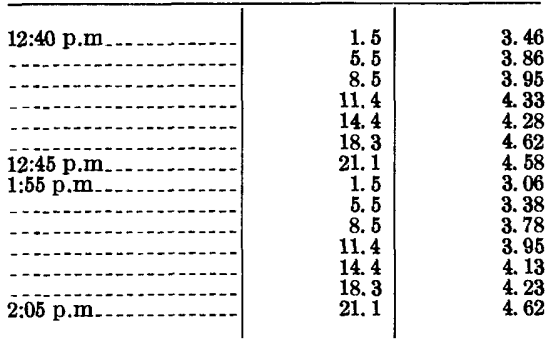

DEC. 27,1955

Station 550; total depth, $11.8 \mathrm{ft}$

\begin{tabular}{r|r|r}
\hline $12: 50$ p.m. & 2.4 & 2.35 \\
\hline $12.55 \mathrm{p} . \mathrm{m}$ & 4.7 & 2.40 \\
$1: 45 \mathrm{p} . \mathrm{m}$ & 7.1 & 2.45 \\
\hdashline $1: 50 \mathrm{p.m}$ & 10.6 & 2.76 \\
& 2.4 & 2.35 \\
& 4.7 & 2.45 \\
& 7.1 & 2.51 \\
\hline
\end{tabular}

Station 925; total depth, $15,2 \mathrm{ft}$

\begin{tabular}{|c|c|c|}
\hline 2:00 p.m & 1.5 & 1.51 \\
\hline - & $\begin{array}{l}3.0 \\
6.1\end{array}$ & $\begin{array}{l}2.16 \\
2.25\end{array}$ \\
\hline $2.05 \mathrm{pm}$ & 9.1 & 2.63 \\
\hline 2:50 p.m. & 1. 5 & 1.55 \\
\hline- & $\begin{array}{l}6.1 \\
9.1\end{array}$ & $\begin{array}{l}2.45 \\
2.57\end{array}$ \\
\hline $2: 55 \mathrm{p} . \mathrm{m}$ & 13.7 & 2.76 \\
\hline
\end{tabular}


TABLE 4.-Vertical distributions of velocity-Continued

\begin{tabular}{c|c|c|}
\hline Time & \multicolumn{2}{|c|}{ Measuring point } \\
\cline { 2 - 3 } & $\begin{array}{c}\text { Distance } \\
\text { from bed (ft) }\end{array}$ & $\begin{array}{c}\text { Velocity } \\
\text { (fps) }\end{array}$ \\
\hline
\end{tabular}

Station 1,275; total depth, $23.7 \mathrm{ft}$

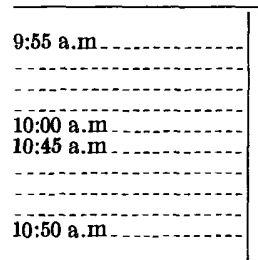

\begin{tabular}{r|r}
2.4 & 1.36 \\
4.7 & 1.39 \\
9.5 & 2.30 \\
14.2 & 2.63 \\
21.3 & 3.01 \\
2.4 & 1.42 \\
4.7 & 1.58 \\
9.5 & 2.01 \\
14.2 & 2.94 \\
21.3 & 2.94 \\
\hline
\end{tabular}

Station 1,525; total depth, $19.5 \mathrm{ft}$

\begin{tabular}{r|r|r}
\hline $11: 00$ a.m & 1.9 & 1.88 \\
\hline $11: 05$ a.m & 3.9 & 2.25 \\
& 11.7 & 2.69 \\
\hline
\end{tabular}

FEB. 21, 1956

Station 550; total depth, $12.0 \mathrm{ft}$

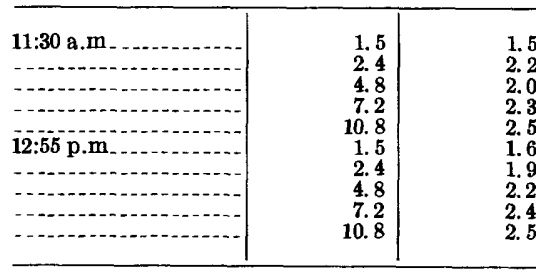

Station 925; total depth, $14.4 \mathrm{ft}$

\begin{tabular}{|c|c|c|}
\hline 1:10 p.m & $\begin{array}{r}1.5 \\
2.9 \\
5.8 \\
8.6 \\
13.0 \\
1.5 \\
2.9 \\
\text { 5. } 8 \\
\text { 8. } 6 \\
13.0\end{array}$ & $\begin{array}{l}1.79 \\
1.99 \\
2.08 \\
2.33 \\
2.85 \\
1.76 \\
1.95 \\
2.48 \\
2.54 \\
2.59\end{array}$ \\
\hline
\end{tabular}

Station 1,275; total depth, $20.5 \mathrm{ft}$

\begin{tabular}{r|r|r}
\hline $2: 40$ p.m & 2.1 & 1.79 \\
\hline 3.35 p.m & 4.1 & 1.76 \\
\hline & 8.2 & 2.38 \\
\hline & 12.3 & 2.85 \\
\hline & 2.1 & 2.97 \\
\hline & 4.1 & 1.79 \\
\hline
\end{tabular}

See footnotes at end of table, p. 54 .

\begin{tabular}{|l|l|c} 
Time & \multicolumn{2}{|c}{ Measuring point } \\
\cline { 2 - 2 } & $\begin{array}{c}\text { Distance } \\
\text { from bed (ft) }\end{array}$ & $\begin{array}{c}\text { Velocity } \\
\text { (fps) }\end{array}$ \\
\hline
\end{tabular}

FEB. 21, 1956-Cortinued

Station 1,525; total depth, $18.5 \mathrm{ft}$

\begin{tabular}{|c|c|c|}
\hline 3:55 p.m. & $\begin{array}{r}1.9 \\
3.7 \\
7.4 \\
11.1 \\
16.7 \\
1.9 \\
3.7 \\
7.4 \\
11.1 \\
16.7\end{array}$ & $\begin{array}{l}1.87 \\
2.24 \\
2.59 \\
2.66 \\
2.72 \\
1.95 \\
2.28 \\
2.33 \\
2.54 \\
2.85\end{array}$ \\
\hline
\end{tabular}

APR. 24, 1956

Station 475; total depth, $29.0 \mathrm{ft}$

\begin{tabular}{r|r|r}
\hline $12: 35$ p.m.2 & 2.9 & 3.04 \\
\hdashline & 5.8 & 3.34 \\
& 11.6 & 3.56 \\
& 17.4 & 4.04 \\
& 26.1 & 4.13
\end{tabular}

Station 900; total depth, $26.8 \mathrm{ft}$

\begin{tabular}{|c|c|c|}
\hline 1:30 p.m.2 ${ }^{2}$ & $\begin{array}{r}2.7 \\
5.4 \\
10.7 \\
16.1 \\
24.1 \\
2.7 \\
5.4 \\
10.7 \\
16.1 \\
24.1\end{array}$ & $\begin{array}{l}\text { 3. } 04 \\
3.26 \\
4.23 \\
4.33 \\
\text { 4. } 72 \\
\text { 3. } 18 \\
\text { 3. } 26 \\
\text { 3. } 87 \\
3.95 \\
4.62\end{array}$ \\
\hline
\end{tabular}

Station 1,300; total depth, $43.0 \mathrm{ft}$

\begin{tabular}{|c|c|c|}
\hline 2:30 p.m.2 ${ }^{2}$ & $\begin{array}{r}4.3 \\
8.6 \\
17.2 \\
25.8 \\
39.0 \\
4.3 \\
8.6 \\
17.2 \\
25.8 \\
39.0\end{array}$ & $\begin{array}{l}\text { 2. } 48 \\
2.09 \\
\text { 3. } 78 \\
\text { 4. } 33 \\
\text { 4. 44 } \\
\text { 1. } 76 \\
\text { 2. } 97 \\
\text { 3. } 26 \\
\text { 4. } 33 \\
\text { 4. } 53\end{array}$ \\
\hline
\end{tabular}

Station 1,575; total dipth, $32.0 \mathrm{ft}$

\begin{tabular}{|c|c|c|}
\hline 3:25 p.m. ${ }^{2}$ & $\begin{array}{r}3.2 \\
6.4 \\
12.8 \\
19.2 \\
28.8 \\
3.2 \\
6.4 \\
12.8 \\
19.2 \\
28.8\end{array}$ & $\begin{array}{l}\text { 2. } 91 \\
\text { 3. } 71 \\
\text { 3. } 87 \\
4.23 \\
\text { 4. } 72 \\
\text { 3. } 26 \\
\text { 3. } 63 \\
4.35 \\
4.35 \\
\text { 5. } 04\end{array}$ \\
\hline
\end{tabular}


TABLE 4.-Vertical distributions of velocity-Continued

\begin{tabular}{|c|c|c|}
\hline \multirow{2}{*}{ Time } & \multicolumn{2}{|c|}{ Measuring point } \\
\hline & $\begin{array}{l}\text { Distance } \\
\text { from bed (ft) }\end{array}$ & $\begin{array}{l}\text { Velocity } \\
\text { (fps) }\end{array}$ \\
\hline \multicolumn{3}{|c|}{ MAY 9, 1956} \\
\hline \multicolumn{3}{|c|}{ Station 475; total depth, $27.6 \mathrm{ft}$} \\
\hline $10: 45$ a.m.2 ${ }^{2}$ & $\begin{array}{r}2.8 \\
5.5 \\
10.0 \\
16.6 \\
24.8 \\
2.8 \\
5.5 \\
10.0 \\
16.6 \\
24.8\end{array}$ & $\begin{array}{l}2.65 \\
3.03 \\
3.18 \\
3.86 \\
4.23 \\
2.78 \\
3.10 \\
3.34 \\
3.95 \\
4.13\end{array}$ \\
\hline \multicolumn{3}{|c|}{ Station 900; total depth, $25.9 \mathrm{ft}$} \\
\hline 11:40 a.m. ${ }^{2}$ & $\begin{array}{r}2.1 \\
5.2 \\
10.4 \\
15.5 \\
23.3 \\
2.1 \\
5.2 \\
10.4 \\
15.5 \\
23.3\end{array}$ & $\begin{array}{l}2.72 \\
\text { 3. } 18 \\
\text { 3. } 95 \\
4.13 \\
\text { 4. } 53 \\
2.23 \\
2.84 \\
3.49 \\
4.04 \\
4.44\end{array}$ \\
\hline
\end{tabular}

Station 1,300; total depth, $41.5 \mathrm{ft}$

\begin{tabular}{r|r|r}
\hline $1: 00$ p.m.2 & 4.1 & 2.03 \\
\hline 1.35 p.m.2 & 6.3 & 2.59 \\
\hline & 16.6 & 3.78 \\
\hline & 24.9 & 3.95 \\
\hline & 37.3 & 4.62 \\
\hline & 6.3 & 1.98 \\
& 16.6 & 2.18 \\
\hline
\end{tabular}

Station 1,577; total depth, $31.5 \mathrm{ft}$

\begin{tabular}{|c|c|c|}
\hline 1:45 p.m.2. & $\begin{array}{r}3.1 \\
6.3 \\
12.6 \\
18.7 \\
28.3 \\
3.1 \\
6.3 \\
12.6 \\
18.7 \\
28.3\end{array}$ & $\begin{array}{l}\text { 3. } 34 \\
\text { 3. } 95 \\
\text { 4. } 13 \\
\text { 4. } 33 \\
\text { 4. } 44 \\
\text { 3. } 18 \\
4.04 \\
4.23 \\
\text { 4. } 33 \\
\text { 4. } 72\end{array}$ \\
\hline
\end{tabular}

\section{JULY 9, 1956}

Station 500; total depth, $25.8 \mathrm{ft}$

\begin{tabular}{l|r|r}
\hline $11: 30$ a.m & 2.6 & 2.85 \\
\hline $12: 00 \mathrm{~m}$ & 5.2 & 3.34 \\
\hline & 10.3 & 3.42 \\
\hline & 23.5 & 3.71 \\
& 2.6 & 4.13 \\
\hline & 5.2 & 2.79 \\
\hline
\end{tabular}

See footnotes at end of table, p. 54 .

\begin{tabular}{|c|c|c|}
\hline \multirow[b]{2}{*}{ Time } & \multicolumn{2}{|c|}{ Measurirg point } \\
\hline & $\begin{array}{c}\text { Distance } \\
\text { from bed (ft) }\end{array}$ & $\begin{array}{c}\text { Velocity } \\
\text { (fps) }\end{array}$ \\
\hline \multicolumn{3}{|c|}{$\begin{array}{c}\text { JULY 9, 1956-Continuer } \\
\text { Station 925; total depth, } 25.7 \mathrm{ft}\end{array}$} \\
\hline 12:05 p.m. & $\begin{array}{r}2.6 \\
5.1 \\
10.3 \\
15.4 \\
23.1 \\
2.6 \\
5.1 \\
10.3 \\
15.4 \\
23.1\end{array}$ & $\begin{array}{l}\text { 2. } 79 \\
\text { 3. } 63 \\
\text { 3. } 95 \\
\text { 3. } 95 \\
\text { 4. 44 } \\
\text { 3. } 04 \\
2.97 \\
\text { 3. } 95 \\
\text { 4. } 23 \\
\text { 4. } 33\end{array}$ \\
\hline
\end{tabular}

Station 1,275; total depth, $38.8 \mathrm{ft}$

\begin{tabular}{r|r|r}
\hline $12: 40$ p.m & 3.9 & 1.99 \\
\hline $1.10 \mathrm{p} . \mathrm{m}$ & 7.8 & 2.20 \\
\hline & 15.5 & 3.11 \\
& 23.3 & 4.13 \\
& 34.9 & 4.82 \\
& 3.9 & 2.48 \\
& 15.5 & 2.04 \\
& 23.3 & 4.26 \\
& 34.9 & 4.72
\end{tabular}

Station 1,575; total depth, $27.0 \mathrm{ft}$

\begin{tabular}{r|r|r}
\hline 1.15 p.m & 3.0 & 2.43 \\
\hline $1.45 \mathrm{p} . \mathrm{m}$ & 6.0 & 3.49 \\
\hline & 12.0 & 3.56 \\
& 18.0 & 4.23 \\
& 27.0 & 4.62 \\
& 3.0 & 2.66 \\
& 6.0 & 3.26 \\
& 12.0 & 3.71 \\
& 18.0 & 4.23 \\
\hline
\end{tabular}

\section{NOV. 5,1956}

Station 600; total depth, $10.5 \mathrm{ft}$

\begin{tabular}{lll}
\hline & 1.5 & 1.80 \\
& 2.1 & 1.91 \\
& 4.2 & 2.38 \\
& 6.3 & 2.33 \\
& 9.5 & 2.33 \\
& 1.5 & 1.69 \\
& 2.1 & 1.95 \\
- & 4.2 & 2.24 \\
& 6.3 & 2.28 \\
\hline
\end{tabular}

Station 1,000; total depth, $15.5 \mathrm{ft}$

\begin{tabular}{r|r}
1.5 & 1.69 \\
3.1 & 1.80 \\
6.2 & 2.43 \\
9.3 & 2.54 \\
13.9 & 2.48 \\
1.5 & 1.69 \\
3.1 & 1.91 \\
6.2 & 2.19 \\
9.2 & 2.66 \\
13.9 & 2.43 \\
\hline
\end{tabular}


TABLE 4.-Vertical distributions of velocity-Continuad

\begin{tabular}{c|c|c}
\hline \multirow{2}{*}{ Time } & \multicolumn{2}{|c}{ Measuring point } \\
\cline { 2 - 3 } & $\begin{array}{c}\text { Distance } \\
\text { from bed (ft) }\end{array}$ & $\begin{array}{c}\text { Velocity } \\
\text { (fps) }\end{array}$ \\
\hline
\end{tabular}

NOV. 5, 1956-Continued

Station 1,375; total depth, $39.3 \mathrm{ft}$

\begin{tabular}{|c|c|c|}
\hline (1) & $\begin{array}{r}1.5 \\
3.9 \\
7.9 \\
15.7 \\
23.6 \\
35.4 \\
1.5 \\
3.9 \\
7.9 \\
15.7 \\
23.6 \\
35.4\end{array}$ & $\begin{array}{l}1.61 \\
1.47 \\
1.69 \\
2.43 \\
2.72 \\
3.34 \\
1.21 \\
1.15 \\
1.65 \\
2.24 \\
2.91 \\
3.26\end{array}$ \\
\hline
\end{tabular}

Station 1,600; total depth, $18.0 \mathrm{ft}$

\begin{tabular}{|c|c|c|}
\hline (1) & $\begin{array}{r}1.5 \\
1.8 \\
3.6 \\
7.2 \\
10.8 \\
16.2 \\
1.5 \\
1.8 \\
3.6 \\
7.2 \\
10.8 \\
16.2\end{array}$ & $\begin{array}{l}1.54 \\
2.24 \\
2.24 \\
2.43 \\
2.97 \\
2.91 \\
1.67 \\
1.87 \\
2.33 \\
2.60 \\
2.97 \\
2.97\end{array}$ \\
\hline
\end{tabular}

APR. 17, 1958

Station 500; total depth, $25.1 \mathrm{ft}$

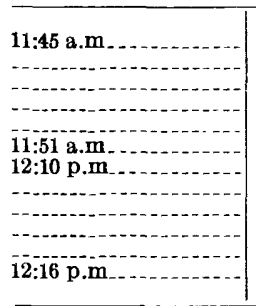

\begin{tabular}{r|}
1.5 \\
2.6 \\
5.0 \\
10.0 \\
15.1 \\
22.6 \\
1.5 \\
2.6 \\
5.0 \\
10.0 \\
15.1 \\
22.6
\end{tabular}

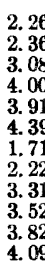

Station 950; total depth, $28.0 \mathrm{ft}$

\begin{tabular}{l|r|r}
\hline $11: 13$ a.m & 1.5 & 2.31 \\
\hline & 2.8 & 2.82 \\
\hline $11: 18$ a.m. & 11.2 & 3.15 \\
$11: 32$ a.m & 16.8 & 3.52 \\
& 25.2 & 3.74 \\
\hline $11: 40$ a.m. & 1.5 & 4.18 \\
\hline
\end{tabular}

See footnotes at end of table, p. 54 .

\begin{tabular}{|l|c|c|} 
Time & \multicolumn{2}{|c}{ Measuring point } \\
\cline { 2 - 3 } & $\begin{array}{c}\text { Distance } \\
\text { from bed (ft) }\end{array}$ & $\begin{array}{c}\text { Velocity } \\
\text { (fps) }\end{array}$ \\
\hline
\end{tabular}

APR. 17, 1958-Continued

Station 1,250; total de rth, $32.0 \mathrm{ft}$

\begin{tabular}{|c|c|c|}
\hline 10:35 a.m 10.0 & $\begin{array}{r}1.5 \\
2.2 \\
6.4 \\
12.8 \\
19.2 \\
28.8 \\
1.5 \\
2.2 \\
6.4 \\
12.8 \\
19.2 \\
28.8\end{array}$ & $\begin{array}{l}\text { 3. } 08 \\
\text { 3. } 21 \\
\text { 3. } 23 \\
\text { 4. } 48 \\
\text { 4. } 57 \\
\text { 4. } 87 \\
\text { 3. } 08 \\
3.31 \\
\text { 3. 59 } \\
\text { 4. } 57 \\
4.67 \\
5.10\end{array}$ \\
\hline
\end{tabular}

Station 1,550; total depth, $27.3 \mathrm{ft}$

\begin{tabular}{|c|c|c|}
\hline 10:00 a.m $10: 05$ a.m $\mathrm{a}$ & $\begin{array}{r}1.5 \\
2.7 \\
5.5 \\
10.9 \\
16.4 \\
24.6 \\
1.5 \\
2.7 \\
5.5 \\
10.9 \\
16.4 \\
24.6\end{array}$ & $\begin{array}{l}3.45 \\
4.08 \\
4.00 \\
4.18 \\
4.87 \\
5.22 \\
3.59 \\
3.39 \\
4.28 \\
4.39 \\
4.98 \\
\text { 5. } 10\end{array}$ \\
\hline
\end{tabular}

MAY 13, 1959

Station 375; total depth, $28.2 \mathrm{ft}$

\begin{tabular}{l|r|r}
\hline $9: 20$ a.m.2 & 2.8 & 2.69 \\
\hdashline $9: 10 \mathrm{a.m} .^{2}$ & 5.6 & 3.59 \\
& 11.3 & 4.57 \\
& 22.6 & 4.41 \\
& 25.4 & 4.38 \\
& & 4.29
\end{tabular}

Station 575; total depth, $30.0 \mathrm{ft}$

\begin{tabular}{|c|c|c|}
\hline 9:40 a.m.2 & $\begin{array}{r}3.0 \\
12.0 \\
18.0 \\
24.0 \\
27.0\end{array}$ & $\begin{array}{l}3.30 \\
4.47 \\
4.66 \\
4.47 \\
5.09\end{array}$ \\
\hline \multicolumn{3}{|c|}{ Station 774; total derth, $32.3 \mathrm{ft}$} \\
\hline 9:55 a.m. ${ }^{2}-1$ & \begin{tabular}{r|}
3.2 \\
12.9 \\
19.4 \\
25.8 \\
29.1
\end{tabular} & $\begin{array}{l}\text { 3. } 32 \\
\text { 4. } 29 \\
\text { 5. } 09 \\
5.21 \\
5.21\end{array}$ \\
\hline
\end{tabular}

Station 924; total denth, $32.8 \mathrm{ft}$

\begin{tabular}{l|r|r}
\hline 10.05 a.m.2 & 3.3 & 4.66 \\
\hdashline $10.00 \mathrm{a.m}$ & 13.1 & 5.09 \\
& 19.7 & 4.98 \\
& 26.2 & 5.47 \\
\hline
\end{tabular}


TABLE 4.-Vertical distributions of velocity-Continued

\begin{tabular}{c|c|c|}
\hline \multirow{2}{*}{ Time } & \multicolumn{2}{|c|}{ Measuring point } \\
\cline { 2 - 3 } & $\begin{array}{c}\text { Distance } \\
\text { from bed (ft) }\end{array}$ & $\begin{array}{c}\text { Velocity } \\
\text { (fps) }\end{array}$ \\
\hline
\end{tabular}

MAY 13, 1959-Continued

Station 1,074; total depth, $35.0 \mathrm{ft}$

\begin{tabular}{l|r|r}
\hline $10: 20$ a.m. & \\
\hline $10: 10$ a.m.2 & 3.5 & 3.99 \\
& 14.0 & 5.34 \\
\hline
\end{tabular}

Station 1,200; total depth, 35.5 ft

\begin{tabular}{r|r|r}
\hline $10: 40$ a.m.2 & 3.6 & 3.52 \\
\hline $10: 30$ a.m. & 14.2 & 5.34 \\
& 21.3 & 5.34 \\
\hline
\end{tabular}

Station 1,300; total depth, $44.3 \mathrm{ft}$

\begin{tabular}{l|r|r}
\hline $11: 00$ a.m.2 & 4.5 & 3.59 \\
\hline $10: 50$ a.m.2. & 17.7 & 5.34 \\
\hline
\end{tabular}

Station 1,425; total depth, $43.2 \mathrm{ft}$

\begin{tabular}{l|r|r}
\hline $11: 20$ a.m.2 & 4.3 & $\mathbf{3 . 5 2}$ \\
\hline $11: 10$ a.m.2. & 17.3 & 5.09 \\
\hline
\end{tabular}

Station 1,551; total depth, $36.2 \mathrm{ft}$

\begin{tabular}{|c|c|c|}
\hline $11: 35$ a.m.2 & $\begin{array}{r}3.6 \\
14.5 \\
21.7 \\
29.0 \\
32.6\end{array}$ & $\begin{array}{l}3.82 \\
5.09 \\
5.66 \\
6.43 \\
6.43\end{array}$ \\
\hline \multicolumn{3}{|c|}{ Station 1,675; total depth, $39.4 \mathrm{ft}$} \\
\hline 11:50 a.m.2 ${ }^{2}$ & $\begin{array}{r}3.9 \\
15.8 \\
23.6 \\
31.5 \\
35.5\end{array}$ & $\begin{array}{l}3.26 \\
4.18 \\
4.76 \\
4.98 \\
4.57\end{array}$ \\
\hline
\end{tabular}

JULY 10, 1959

Station 710; total depth, $32.7 \mathrm{ft}$

\begin{tabular}{l|r|r|}
\hline $9: 20$ a.m. & 1.5 & 1.82 \\
\hline & 3.3 & 1.63 \\
& 6.5 & 1.93 \\
& 9.8 & 2.89 \\
\hline $9: 33$ a.m & 13.1 & 2.70 \\
\hline
\end{tabular}

See footnotes at end of table, p. 54 .

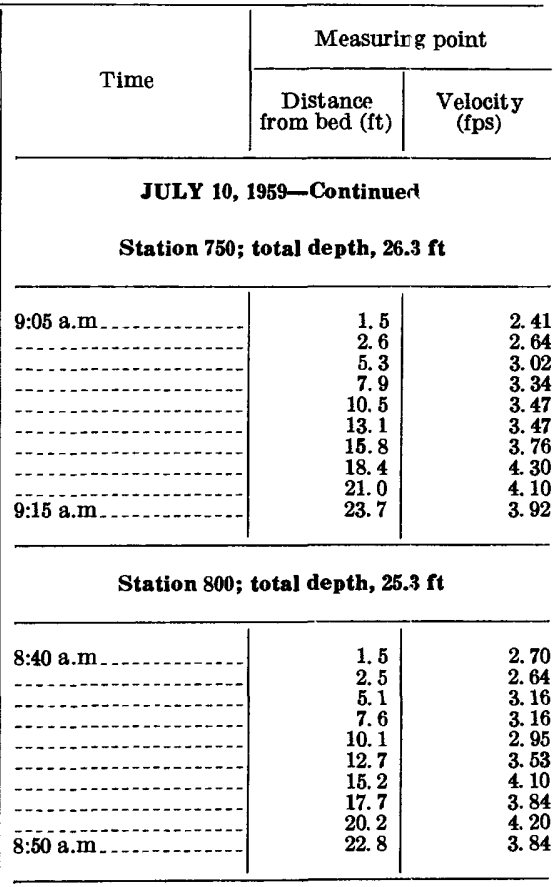

Station 1,000; total depth, $295 \mathrm{ft}$

\begin{tabular}{|c|c|c|}
\hline \begin{tabular}{l}
$8: 20$ a.m \\
$8: 30$ a.m \\
\\
\hdashline
\end{tabular} & $\begin{array}{r}1.5 \\
2.9 \\
5.9 \\
8.9 \\
11.8 \\
14.7 \\
17.7 \\
20.7 \\
23.6 \\
26.5\end{array}$ & $\begin{array}{l}\text { 2. } 77 \\
\text { 2. } 64 \\
\text { 3. } 09 \\
\text { 3. } 92 \\
\text { 3. } 47 \\
\text { 4. } 10 \\
\text { 4. } 20 \\
\text { 4. } 01 \\
4.20 \\
4.41\end{array}$ \\
\hline
\end{tabular}

APR. 14, 1960

Station 351; total depth, 42.7 ft

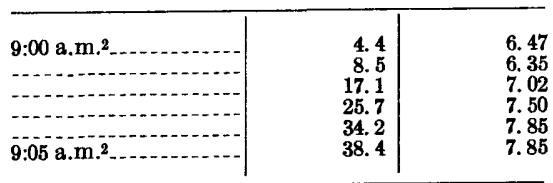

Station 525; total depth, $46.5 \mathrm{ft}$

\begin{tabular}{l|r|r}
\hline 9.15 a.m.2. & 4.7 & 4.69 \\
\hline 9.20 a.m.2. & 9.3 & 5.51 \\
& 18.7 & 7.50 \\
& 28.0 & 7.50 \\
& 37.3 & 7.50 \\
\hline
\end{tabular}


TABLE 4.-Vertical distributions of velocity-Continued

\begin{tabular}{c|c|c|}
\hline \multirow{2}{*}{ Time } & \multicolumn{2}{|c}{ Measuring point } \\
\hline $\begin{array}{c}\text { Distance } \\
\text { from bed (ft) }\end{array}$ & $\begin{array}{c}\text { Velocity } \\
\text { (fps) }\end{array}$ \\
\hline
\end{tabular}

APR. 14, 1960-Continued

Station 750; total depth, $48.4 \mathrm{ft}$

\begin{tabular}{r|r|r}
\hline $9: 45$ a.m.2 & 4.8 & 5.37 \\
\hline $9: 50$ a.m.2. & 9.7 & 6.60 \\
\hline & 19.4 & 7.17 \\
\hline
\end{tabular}

Station 924; total depth, $51.2 \mathrm{ft}$

\begin{tabular}{l|r|r}
\hline $10: 05$ a.m. & \\
\hline & 5.1 & 5.37 \\
\hline $10: 10$ a.m.2 & 10.2 & 5.37 \\
\hline
\end{tabular}

Station 1,074; total depth, $50.0 \mathrm{ft}$

\begin{tabular}{l|r|r}
\hline $10: 25$ a.m.2. & 5.0 & 6.11 \\
\hline $10: 30$ a.m.2. & 10.0 & 6.23 \\
\hline
\end{tabular}

Station 1,200; total depth, $54.7 \mathrm{ft}$

\begin{tabular}{l|r|r}
\hline $10: 35$ a.m & 5.4 & 6.11 \\
\hline $10: 40$ a.m.2.2. & 10.9 & 6.11 \\
\hline
\end{tabular}

Station 1,320; total depth, $58.2 \mathrm{ft}$

\begin{tabular}{l|r|r}
\hline $10: 50$ a.m.2 & 5.8 & 7.17 \\
\hline & 11.6 & 8.24 \\
\hline $10: 55$ a.m.2 & 23.3 & 8.79 \\
& 34.9 & 9.55 \\
& 46.6 & 9.98 \\
\hline
\end{tabular}

Station 1,451; total depth, $61.6 \mathrm{ft}$

\begin{tabular}{l|r|r}
\hline $11: 15$ a.m.2 & 6.1 & 7.33 \\
\hdashline $11: 20$ a.m.2 & 12.3 & 8.62 \\
\hline & 24.7 & 8.79 \\
\hline
\end{tabular}

Station 1,551; total depth, $61.1 \mathrm{ft}$

\begin{tabular}{r|r|r}
\hline $11: 30$ a.m. & \\
\hline 11.35 a.m. ${ }^{2}$ & 6.1 & 8.14 \\
\hline
\end{tabular}

See footnotes at end of table, p. 54.

\begin{tabular}{|l|c|c} 
Time & \multicolumn{2}{|c}{ Measuring point } \\
\hline $\begin{array}{c}\text { Distarce } \\
\text { from bec (ft) }\end{array}$ & $\begin{array}{c}\text { Velocity } \\
\text { (fps) }\end{array}$ \\
\hline
\end{tabular}

APR. 14, 1960-Cortinued

Station 1,701; total de $7 \mathrm{th}, 52.6 \mathrm{ft}$

\begin{tabular}{r|r|r}
\hline $11: 55$ a.m.2 & 5.3 & 6.11 \\
\hline $12: 00 \mathrm{~m}$ & 10.5 & 6.35 \\
\hline
\end{tabular}

JUNE 21, 19:M

Station 375; total derth, 23.3 ft

\begin{tabular}{r|r|r}
\hline $9: 25$ a.m.2 & 2.3 & 3.07 \\
\hline $9: 15$ a.m.2. & 4.7 & 3.07 \\
\hline & 9.3 & 3.21 \\
& 14.0 & 3.99 \\
& 18.6 & 4.18 \\
& 21.0 & 4.76
\end{tabular}

Station 575; total derth, 22.7 ft

\begin{tabular}{lr|r}
\hline $9: 50$ a.m.2 & 2.3 & 3.38 \\
\hline $9: 40$ a.m.2 & 4.5 & 3.99 \\
\hline & 13.6 & 3.99 \\
\hline
\end{tabular}

Station 750; total depth, $31.0 \mathrm{ft}$

\begin{tabular}{l|r|r}
\hline $10: 15$ a.m.2 & 3.1 & $\mathbf{3} .58$ \\
\hdashline $10: 05$ a.m. & 12.4 & 3.42 \\
\hline
\end{tabular}

Station 950; total de 7 th, $31.7 \mathrm{ft}$

\begin{tabular}{|c|c|c|}
\hline $10: 30 \mathrm{a.m}{ }^{2} \mathrm{~s}$ & $\begin{array}{r}3.2 \\
6.3 \\
12.7 \\
19.0 \\
25.4 \\
28.5\end{array}$ & $\begin{array}{l}\text { 3. } 66 \\
\text { 4. } 08 \\
\text { 3. } 99 \\
\text { 4. } 98 \\
\text { 4. } 87 \\
\text { 5. } 22\end{array}$ \\
\hline
\end{tabular}

Station 1,100; total dipth, $36.8 \mathrm{ft}$

\begin{tabular}{l|r|r}
\hline $10: 45$ a.m.2 & 3.7 & 2.87 \\
\hdashline 10.4 & 3.82 \\
\hdashline 0.35 a.m.2. & 14.7 & 4.18 \\
& 22.1 & 4.66 \\
\hline
\end{tabular}


TABLE 4.-Vertical distributions of velocity-Continued

\begin{tabular}{|c|c|c|c|c|c|}
\hline \multirow{2}{*}{ Time } & \multicolumn{2}{|c|}{ Measuring point } & \multirow{2}{*}{ Time } & \multicolumn{2}{|c|}{ Measuring point } \\
\hline & $\begin{array}{c}\text { Distance } \\
\text { from bed (ft) }\end{array}$ & $\begin{array}{l}\text { Velocity } \\
\text { (fps) }\end{array}$ & & $\begin{array}{c}\text { Distance } \\
\text { from bed (ft) }\end{array}$ & $\begin{array}{l}\text { Velocity } \\
\text { (fps) }\end{array}$ \\
\hline \multicolumn{3}{|c|}{$\begin{array}{c}\text { JUNE 21, } 1960-\text { Continued } \\
\text { Station 1,200; total depth, } 38.0 \text { ft }\end{array}$} & \multicolumn{3}{|c|}{$\begin{array}{l}\text { JUNE 21, 1960-Continued } \\
\text { Station 1,601; total depth, 4).5 ft }\end{array}$} \\
\hline $10: 55$ a.m. ${ }^{2}$ & $\begin{array}{r}3.8 \\
7.6 \\
15.2 \\
22.8 \\
30.4 \\
34.2\end{array}$ & $\begin{array}{l}\text { 3. } 07 \\
4.08 \\
5.09 \\
4.57 \\
5.48 \\
5.22\end{array}$ & 11:30 a.m.2 & $\begin{array}{r}4.0 \\
8.1 \\
16.2 \\
24.3 \\
32.4 \\
36.5\end{array}$ & $\begin{array}{l}\text { 3. } 82 \\
3.90 \\
4.57 \\
4.66 \\
5.09 \\
5.34\end{array}$ \\
\hline \multicolumn{3}{|c|}{ Station 1,320 ; total depth, $51.4 \mathrm{ft}$} & \multicolumn{3}{|c|}{ Station 1,701; total depth, $44.0 \mathrm{ft}$} \\
\hline 11:10 a.m.2 & $\begin{array}{r}5.2 \\
10.3 \\
20.6 \\
30.8 \\
41.1 \\
46.3\end{array}$ & $\begin{array}{l}2.50 \\
4.38 \\
4.57 \\
5.48 \\
5.48 \\
5.48\end{array}$ & 11:45 a.m.2 ${ }^{2}$ & $\begin{array}{r}4.4 \\
8.8 \\
17.6 \\
26.4 \\
35.2 \\
39.6\end{array}$ & $\begin{array}{l}2.62 \\
2.56 \\
\text { 3. } 38 \\
\text { 3. } 58 \\
\text { 3. } 74 \\
\text { 3. } 58\end{array}$ \\
\hline
\end{tabular}

${ }^{1}$ A verage for about 11-15 seconds. ${ }_{2}^{2}$ Estimated. 3 Average for about 115-130 seconds.

Velocity distributions at each of four or more stations in the cross section defined the average $k$ 's that are shown in columns 4 and 5 of table 5. The $k$ 's in column 4 were obtained by averaging the computed $k$ 's for the individual stations; the $k$ 's in column 5 were computed from the averages of the differences in velocity for a 10 to 1 change in distance above the streambed for the individual stations. T e difference between the two types of average $k$ 's is a rough measure of the uniformity of the $k$ 's for the individual stations and is small unless, as on May 13, 1959, $k$ for one of the stations is large. The averages of the $k$ 's in columns 5 and 6 are 0.35 and 0.33 , respectively.

As relatively few vertical distributions of velocity were defined by current-meter observations, $k$ was also computed from the velocities of routine discharge measurements. Differences between the velocities at 0.2 and at 0.8 of the depth for all stations except those nenr banks and piers were added, and the total was divided by the number of stations to obtain the average velocity difference per station. The Keulegan type of equation for point velocity indicates that the velocity difference equals $2.30\left(u_{*} / k\right) \log 4$ or $1.39 u_{*} / k$ for a relative change of 4 to $1(0.8$ to 0.2$)$ in the distance above the streambed. Hence, $k$ for the cross section was computed by dividing $1.39 u_{*}$ by the average velocity difference per station. 
TABLE 5.-Turbulence constants based on vertical distributions of velocity

\begin{tabular}{|c|c|c|c|c|c|}
\hline \multirow[b]{2}{*}{ Date } & \multirow[b]{2}{*}{$\begin{array}{l}\text { Daily mean } \\
\text { discharge } \\
(1,000 \mathrm{cfs})\end{array}$} & \multirow[b]{2}{*}{$\begin{array}{c}\text { Water- } \\
\text { surface slope }\end{array}$} & \multicolumn{3}{|c|}{ Average $k$ for cross section from- } \\
\hline & & & $\begin{array}{l}\text { Average of } \\
k \text { 's for } \\
\text { stations } \\
\\
\text { (4) }\end{array}$ & 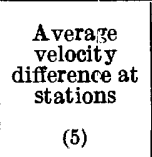 & $\begin{array}{l}\text { Discharge } \\
\text { measure- } \\
\text { ments } \\
\\
(6)\end{array}$ \\
\hline $\begin{array}{c}\text { Mar. } 2 \\
\text { May } 21.48 \\
\end{array}$ & $\begin{array}{l}327 \\
214\end{array}$ & $\begin{array}{r}0.0000551 \\
.0000589\end{array}$ & $\begin{array}{r}0.21 \\
.36\end{array}$ & $\begin{array}{r}0.21 \\
.36\end{array}$ & 0.21 \\
\hline $\begin{array}{l}\text { May } 8 \\
\text { May } 22 \\
\text { June } 5\end{array}$ & $\begin{array}{l}330 \\
347 \\
326\end{array}$ & $\begin{array}{l}.0000997 \\
.0000924 \\
.0000909\end{array}$ & - . & (-n-1 & $\begin{array}{l}.33 \\
.32 \\
.31\end{array}$ \\
\hline $\begin{array}{l}\text { Apr. } 17 \\
\text { Apr. } 19 \\
\text { July } 16 \\
\text { July } 22 \\
\text { July } 30 \\
\text { Sept. } 17\end{array}$ & $\begin{array}{l}527 \\
496 \\
704 \\
765 \\
472 \\
387\end{array}$ & $\begin{array}{l}.000106 \\
.000107 \\
.000126 \\
.000139 \\
.0000851 \\
.0000632\end{array}$ & 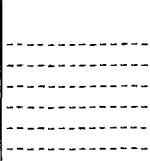 & 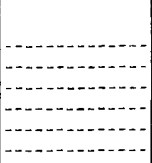 & $\begin{array}{l}.37 \\
.31 \\
.38 \\
.34 \\
.27 \\
.22\end{array}$ \\
\hline $\begin{array}{l}\text { Mar. } 17-1952 \\
\text { Apr. } 30\end{array}$ & $\begin{array}{l}411 \\
682\end{array}$ & $\begin{array}{l}.0000661 \\
.000110\end{array}$ & $\begin{array}{r}.30 \\
1.24\end{array}$ & .28 & .35 \\
\hline $\begin{array}{l}\text { June } 7 \\
\text { Jug. } 9 \\
\text { Aug. } 10 \\
\text { Aug. } 27\end{array}$ & $\begin{array}{l}281 \\
115 \\
111 \\
118\end{array}$ & $\begin{array}{l}.0000691 \\
.0000647 \\
.0000633 \\
.0000720\end{array}$ & \begin{tabular}{r|}
.40 \\
1.35 \\
1.44
\end{tabular} & $\begin{array}{r}.40 \\
-40 \\
-0.0 . \\
\end{array}$ & $\begin{array}{r}.34 \\
.33 \\
.3 \\
-. .\end{array}$ \\
\hline $\begin{array}{l}1955 \\
\text { Mar. 30, 31 } \\
\text { Dec. 27, 28 }\end{array}$ & $\begin{array}{c}163 \\
57.4\end{array}$ & $\begin{array}{l}.0000793 \\
.0000822\end{array}$ & $\begin{array}{l}.41 \\
.37\end{array}$ & $\begin{array}{l}.40 \\
.36\end{array}$ & $\begin{array}{l}.37 \\
.39\end{array}$ \\
\hline $\begin{array}{l}\text { Feb. } 21 \\
\text { Apr. 24 } \\
\text { May 9 } \\
\text { July } 9\end{array}$ & $\begin{array}{l}56.1 \\
169 \\
159 \\
154\end{array}$ & $\begin{array}{l}.0000822 \\
.0000836 \\
.0000836 \\
.0000749\end{array}$ & $\begin{array}{l}.40 \\
.39 \\
.37 \\
.34\end{array}$ & $\begin{array}{l}.40 \\
.37 \\
.35 \\
.32\end{array}$ & $\begin{array}{l}.58 \\
.32 \\
.32 \\
.32\end{array}$ \\
\hline Apr. 17.... & 164 & .0000962 & .40 & .39 & .... \\
\hline $\begin{array}{l}\text { May } 13 \\
\text { July } 10\end{array}$ & $\begin{array}{l}240 \\
150\end{array}$ & $\begin{array}{l}.0000903 \\
.0000670\end{array}$ & $\begin{array}{l}.40 \\
.32\end{array}$ & $\begin{array}{l}.34 \\
.32\end{array}$ & .25 \\
\hline \begin{tabular}{l}
\multicolumn{1}{c}{1960} \\
Apr. 14
\end{tabular} & $\begin{array}{l}2581 \\
2211\end{array}$ & $\begin{array}{l}.000131 \\
.0000728\end{array}$ & $\begin{array}{r}.40 \\
.34\end{array}$ & $\begin{array}{l}.35 \\
.34\end{array}$ & $\begin{array}{l}.37 \\
.33\end{array}$ \\
\hline
\end{tabular}

1 One station only.

2 Measured discharge.

The $11 k$ 's computed from discharge measurements averaged almost the same -0.345 as compared with 0.349 (table 5 , cols. 6,5 ), as the $11 k$ 's determined on the same days from several valocity observations at each of a few stations. Theoretically, the $k$ 's in column 5 , which are based on measured velocities at only a few stations, should represent the average vertical distribution of velocity more closely for the measuring stations and less closely for the whole cross section 
than the $k$ 's in column 6 , which are based on velocities at about 20-30 stations. Actually, the differences in the two types of $k$ 's may be due mainly to experimental errors.

The method for computing $k$ from discharge measurements is simple and rapid and usually requires no additional fieldwork except determining a reasonably accurate energy gradient. Although the velocity differences may be much less consistent from one station to another in shallow flows over dune beds than in the deep flcws of the Mississippi River, the vertical distributions defined by many observations at only a few stations are also likely to be less consistent. For such shallow flows, the velocity differences for the large number of stations that are included in a discharge measurement, especially if the stations are spaced randomly with respect to the dunes, may provide a more representative vertical distribution of velocity for the cross section than the vertical distribution that can be obtained from detailed information for only a few stations.

The turbulence constants, mostly computed from discharge measurements, are fairly consistent (fig. 20) with those reported by Einstein and Chien (1955, fig. 15). Individual $k$ 's scatter considerably from the curve perhaps partly because of the rough streambed of the Mississippi River at St. Louis. Also, the data for flume studies and for the Missouri River, collected primarily for research stucies, probably were more accurate than some of the routinely determir ad watersurface slopes at St. Louis and some velocity differences computed from discharge measurements. The $k$ 's based on 22 discharge measurements for the Mississippi River at St. Louis (table 5) average 0.33, which is considerably less than 0.40 but somewhat greater tr an would be indicated by the curve (fig. 20) that was defined by Eirstein and Chien.

\section{SEDIMENT CONCENTRATION}

The usual equation for the vertical distribution of suspended sediment of a particular fall velocity is

$$
\frac{c_{y}}{c_{a}}=\left(\frac{y_{0}-y}{y} \frac{a}{y_{0}-a}\right)^{2}
$$

in which

$c_{y}$ and $c_{a}$ are concentrations of sediment of a particular fall velc city at distances $y$ and $a$, respectively, above the streambed

$z$ theoretically equals the fall velocity $w$ divided by $k u_{*}$ 


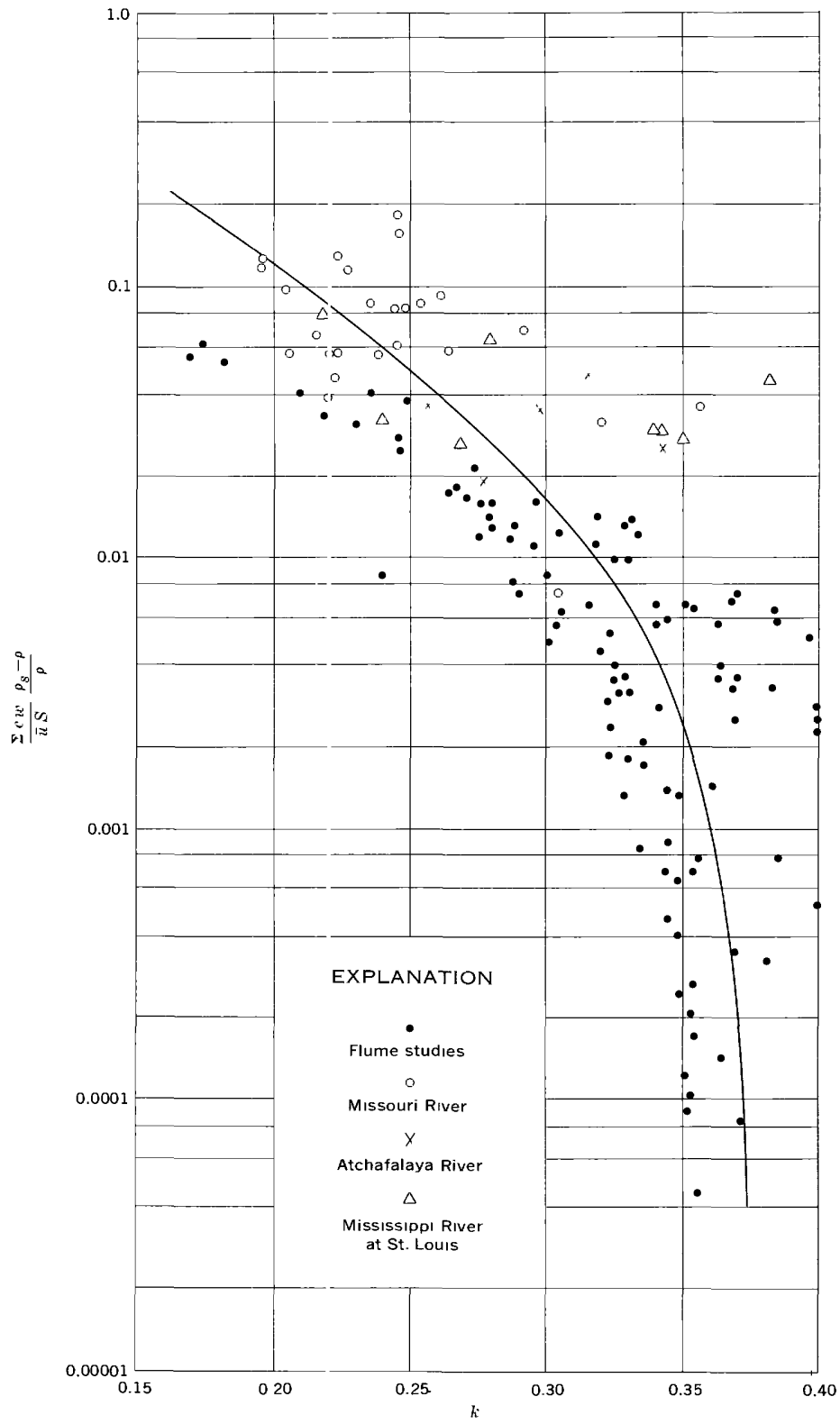

FIGURE 20.-Effect of sediment on the turbulence constant computed from the vertical distribution of velocity. Data for the Mississippi River added to figure 15 of Einstein and Chien (1955). 
TABLE 6.-Values of $z_{1}$ from point samples

\begin{tabular}{|c|c|c|c|c|c|c|c|c|c|}
\hline \multirow[b]{2}{*}{ Date } & \multirow{2}{*}{$\begin{array}{l}\text { Sampling } \\
\text { station }\end{array}$} & \multicolumn{3}{|c|}{$\begin{array}{l}z_{1} \text { for indicated } \\
\text { particle-size range }\end{array}$} & \multirow[b]{2}{*}{ Date } & \multirow{2}{*}{$\begin{array}{l}\text { Sampling } \\
\text { station }\end{array}$} & \multicolumn{3}{|c|}{$\begin{array}{l}z_{1} \text { for indicated } \\
\text { particle-size range }\end{array}$} \\
\hline & & $\begin{array}{c}<0.062 \\
\mathrm{~mm}\end{array}$ & \begin{tabular}{|c}
$0.062-$ \\
0.125 \\
$\mathrm{~mm}$
\end{tabular} & $\begin{array}{l}0.125- \\
0.250 \\
\mathrm{~mm}\end{array}$ & & & $\begin{array}{c}<0.062 \\
\mathrm{~mm}\end{array}$ & $\begin{array}{c}0.063- \\
0.125 \\
\mathrm{mrn}\end{array}$ & $\begin{array}{c}0.125- \\
0.250 \\
\mathrm{~mm}\end{array}$ \\
\hline $\begin{array}{r}1950 \\
\text { May } 8\end{array}$ & $\begin{array}{r}400 \\
1200\end{array}$ & $\begin{array}{r}0.01 \\
.02\end{array}$ & 0.12 & 0.38 & $\begin{array}{l}\text { 1952-Con. } \\
\text { May 1-Con. }\end{array}$ & 1275 & $\begin{array}{l}0.03 \\
04\end{array}$ & 0.21 & 0.29 \\
\hline May 23. & $\begin{array}{r}1500 \\
400\end{array}$ & $\begin{array}{l}.06 \\
.02\end{array}$ & 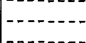 & .28 & 1953 & 500 & 03 & 26. & 56 \\
\hline & $\begin{array}{l}625 \\
900\end{array}$ & .02 & 02 & $\cdots$ & & $\begin{array}{r}900 \\
1275\end{array}$ & .06 & .27 & $\begin{array}{r}.83 \\
1.32 \\
1.32\end{array}$ \\
\hline & 1100 & .04 & .02 & 烈 & & 1575 & .01 & .26 & .77 \\
\hline & $\begin{array}{l}1250 \\
1400\end{array}$ & $\begin{array}{l}.01 \\
.01\end{array}$ & $\cdots$ & $\begin{array}{l}.14 \\
.41\end{array}$ & Sept. 15 & $\begin{array}{l}525 \\
925\end{array}$ & $\begin{array}{l}.01 \\
.01\end{array}$ & $\begin{array}{l}.30 \\
.30\end{array}$ & .73 \\
\hline & $\begin{array}{l}1500 \\
1650\end{array}$ & 0 & 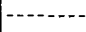 & .24 & & 1275 & $\begin{array}{l}0 \\
\end{array}$ & .30 & .59 \\
\hline June $7 \ldots$ & 400 & .02 & $-\cdots$ & .21 & & & & & \\
\hline & $\begin{array}{l}120 \\
150 \\
150\end{array}$ & .02 & $\cdots$ & .12 & June 7954 & 475 & .01 & $22>$ & \\
\hline Aug. 8.. & $\begin{array}{r}400 \\
1200\end{array}$ & .05 & 08 & 07 & & $\begin{array}{r}900 \\
1275\end{array}$ & .02 & .25 & $\begin{array}{r}.75 \\
1.02\end{array}$ \\
\hline Sept. 7 & $\begin{array}{r}1500 \\
400\end{array}$ & .02 & .12 & 43 & & 1600 & .04 & .27 & .72 \\
\hline & 1200 & .04 & & .45 & 10 & & & & \\
\hline Sept. 26... & $\begin{array}{r}1500 \\
400\end{array}$ & .02 & $\begin{array}{l}.07 \\
.47\end{array}$ & .32 & Mar. & $\begin{array}{r}500 \\
925\end{array}$ & .02 & .13 & $\begin{array}{l}.49 \\
.42\end{array}$ \\
\hline & $\begin{array}{l}1200 \\
1500\end{array}$ & . .01 & . . . .99 & $\begin{array}{r}.35 \\
.47\end{array}$ & & $\begin{array}{l}1275 \\
1575\end{array}$ & & .14 & $\begin{array}{l}.41 \\
.32 \\
\end{array}$ \\
\hline $\begin{array}{l}1951 \\
\text { Apr. } 18 . . .\end{array}$ & 450 & .02 & & & Dec. $27 \ldots$ & $\begin{array}{l}550 \\
925\end{array}$ & $0^{.03}$ & .26 & .82 \\
\hline & $\begin{array}{r}920 \\
1250\end{array}$ & .06 & .27 & & 1956 & 1275 & .08 & .10 & .74 \\
\hline July 16 & 1600 & . 01 & .14 & .36 & Feb. 21 & 550 & 0 & .41 & .43 \\
\hline & $\frac{12}{16}$ & $\cdots$ & .09 & 23 & & $\begin{array}{l}1275 \\
1575\end{array}$ & .02 & .05 & .67 \\
\hline July 22 & $\begin{array}{l}450 \\
875\end{array}$ & .01 & $\cdots$ & 32 & Apr. 24 & $\begin{array}{l}475 \\
900\end{array}$ & .02 & .29 & $\begin{array}{r}49 \\
48\end{array}$ \\
\hline & 1250 & $\cdots-\cdots$ & $\cdots$ & .27 & & 1300 & & .18 & 48 \\
\hline July 30 & 450 & .02 & $\cdots$ & .20 & May $9 .$. & 475 & .02 & .26 & .76 \\
\hline & $\begin{array}{l}870 \\
1250\end{array}$ & .02 & .10 & .25 & & $\begin{array}{l}900 \\
1300\end{array}$ & .01 & .41 & .70 \\
\hline Sept. 17 . & 475 & .02 & .22 & & 10 & 1575 & .05 & & .95 \\
\hline & $\begin{array}{l}900 \\
1275\end{array}$ & & 16 & $\cdots$ & Juy $9 .$. & 925 & .02 & .33 & .75 \\
\hline Sept. 26. & $\begin{array}{r}1600 \\
475\end{array}$ & & .14 & .38 & & 1275 & .07 & .31 & .67 \\
\hline Nopo. 20 & 900 & .01 & .20 & & May $13_{-}$ & 375 & .01 & .04 & .62 \\
\hline & 1275 & .03 & .21 & $\ldots$ & & & $0^{02}$ & .03 & .17 \\
\hline Oct. $17 \ldots$ & 475 & .03 & .03 & .48 & & $\begin{array}{l}775 \\
925\end{array}$ & .02 & .25 & .49 \\
\hline & $\begin{array}{r}900 \\
1275\end{array}$ & .02 & .37 & & & $\begin{array}{l}1075 \\
1200\end{array}$ & $\begin{array}{l}.03 \\
.03\end{array}$ & .27 & $\begin{array}{r}.57 \\
.42\end{array}$ \\
\hline Nov 13 & 1600 & .05 & & .68 & & 1300 & .04 & .23 & .59 \\
\hline $100 \mathrm{~V} .10-$ & $\begin{array}{l}\begin{array}{l}450 \\
900\end{array} \\
\end{array}$ & .02 & .24 & .51 & & 1550 & .02 & .22 & .33 \\
\hline & $\begin{array}{l}1275 \\
1600\end{array}$ & $\cdots$ & .48 & ..... & Julv 10 & $\begin{array}{r}1675 \\
710\end{array}$ & .03 & .16 & .53 \\
\hline May & & & & & & $\begin{array}{l}750 \\
800\end{array}$ & .02 & .13 & .96 \\
\hline a & 850 & .01 & .09 & .20 & & 1000 & .01 & .15 & 55 \\
\hline
\end{tabular}

This equation is based on the assumption that the water surface and streambed are plane and parallel. In general, the form of the equation has been found to be correct except that the actual exponent, called $z_{1}$, generally differs materially from $w /\left(k u_{*}\right)$ (Anderson, 1942 ; Vanoni, 1946; Einstein and Chien, 1954). 
The $z_{1}$ 's for the Mississippi River at St. Louis were computed for most times when point-integrated sediment samples from each of several points at a station were analyzed for sediment concentration and particle size. Each $z_{1}$ for a station and a size range is listed in table 6 and was determined by measuring the slope of the straight line through the plotted points of the logarithm of the concentration for a size range against the logarithm of $\left(y_{0}-y\right) / y$. Some plotted points were too irregularly and widely scattered to define a line, and the $z_{1}$ 's based on the slopes of other lines were obviously inconsistent from one size range to the other. In general, the $z_{1}$ 's were more consistent and seemed to be more dependable after March 31, 1955, when the size analyses of the sands were made with the visual-accumulation tube (see table 7), than the $z_{1}$ 's on or before March 31,1955 , when the size analyses of sands were made with the bottom-withdrawal tube. 


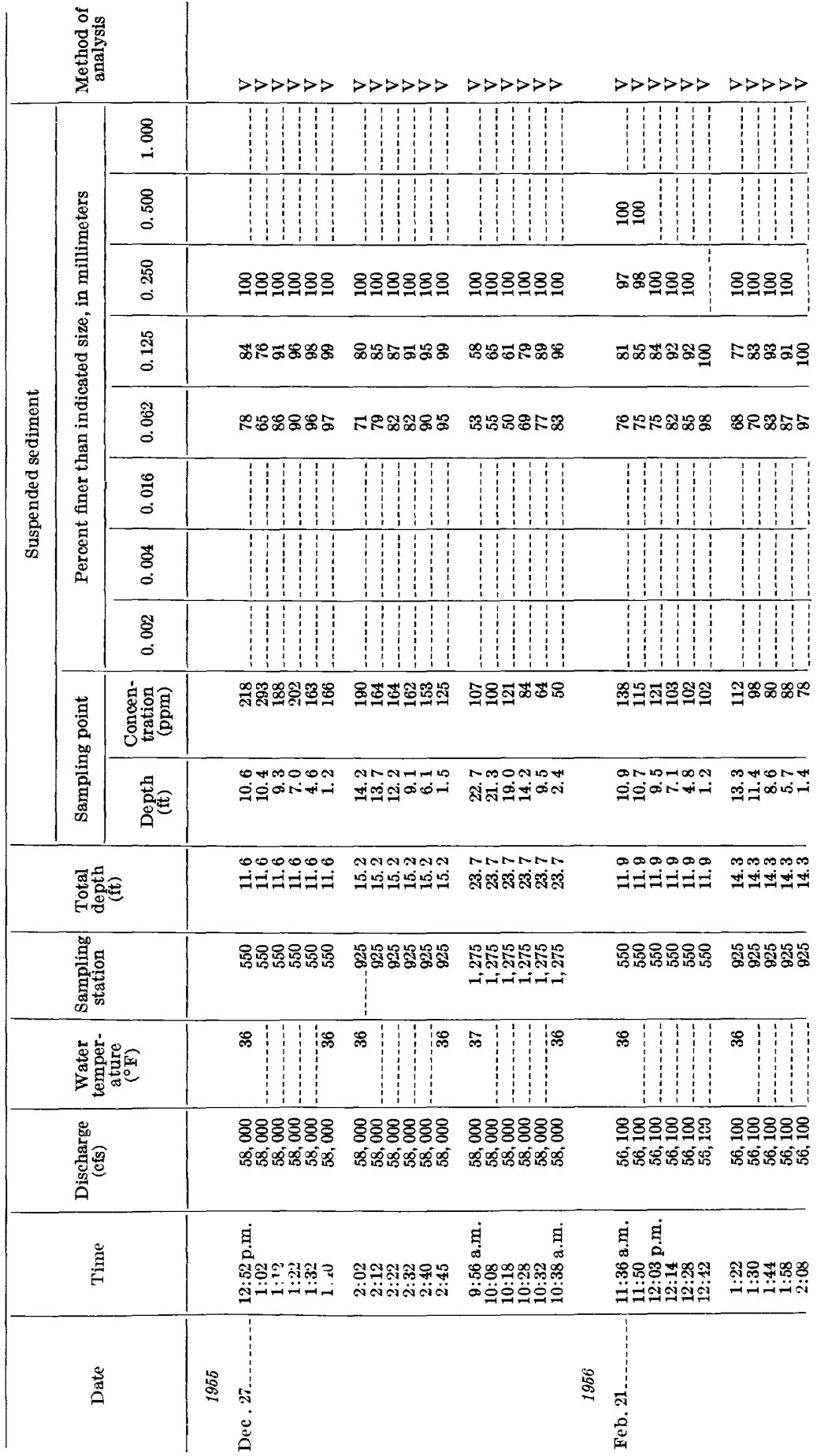




\begin{tabular}{|c|c|c|c|c|c|c|}
\hline$\Rightarrow P P D$ & $\Rightarrow P D D$ & 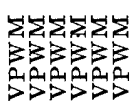 & 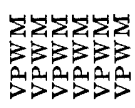 & 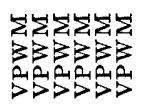 & 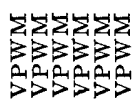 & 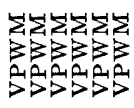 \\
\hline 1 & & & 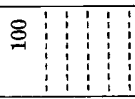 & 8 & 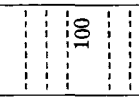 & 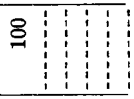 \\
\hline 8 & 888 & 88. & œ8 & 858 & 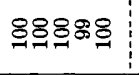 & 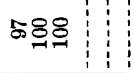 \\
\hline క్రం్రి & ৪ళ & ఋ & 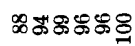 & இஃ & 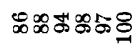 & œ৪৪৪্] \\
\hline
\end{tabular}

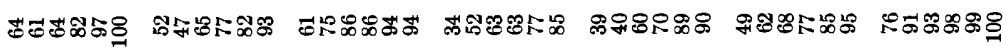

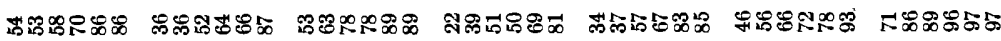

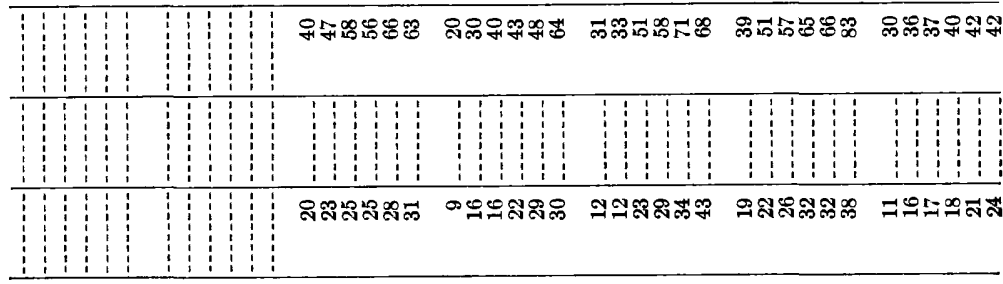

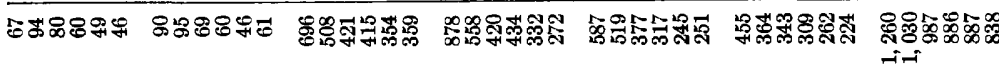

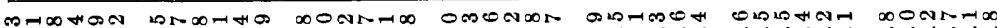

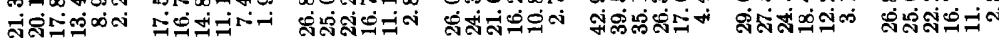

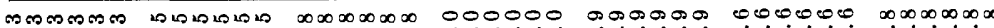

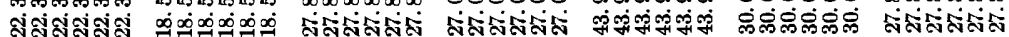

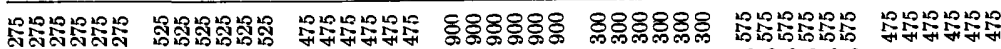

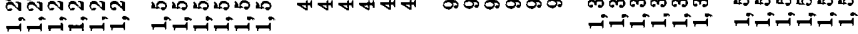

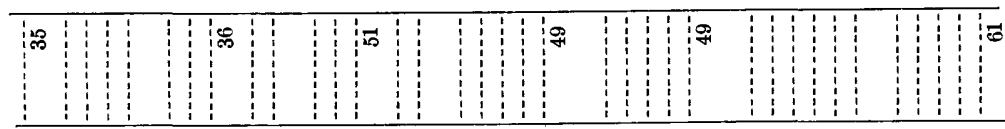

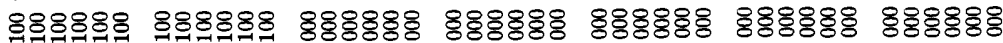

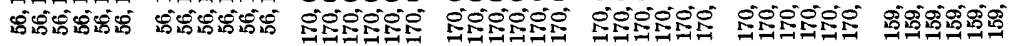

\begin{tabular}{|c|c|c|c|c|c|c|}
\hline 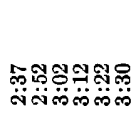 & 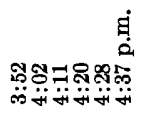 & 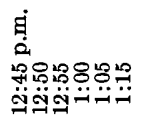 & 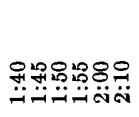 & 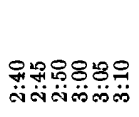 & 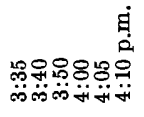 & 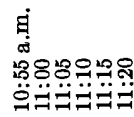 \\
\hline & & 㻤 & & & & 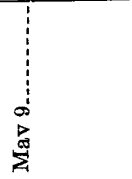 \\
\hline
\end{tabular}




\begin{tabular}{|c|c|c|c|c|c|c|c|}
\hline \multicolumn{3}{|c|}{ 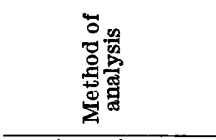 } & 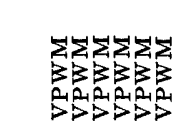 & 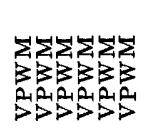 & 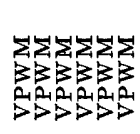 & 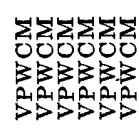 & 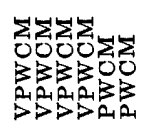 \\
\hline \multirow{10}{*}{ 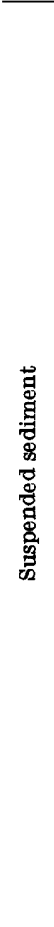 } & \multirow{8}{*}{ 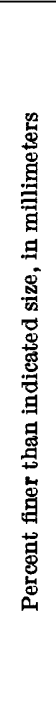 } & $\stackrel{8}{-}$ & 8 & & & & \\
\hline & & $\begin{array}{l}\text { : } \\
0 \\
0\end{array}$ & ర్తారి & 8ర్తిర్తి: & 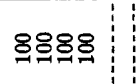 & & \\
\hline & & $\begin{array}{l}\text { 令 } \\
0 \\
0\end{array}$ & ஃణஃర్తిర్తిర్త & ஃக5ర్తింర్త & எ쇼88 & 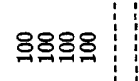 & 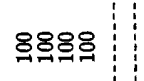 \\
\hline & & $\stackrel{2}{7}$ & 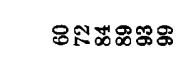 & ஓボஜ゚ダ & 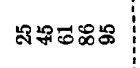 & 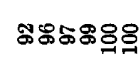 & ஃ5ஃฎ8 \\
\hline & & $\begin{array}{l}\text { ஜ̊̀ } \\
\vdots \\
0\end{array}$ & 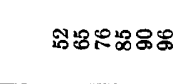 & 구눙요 & 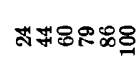 & 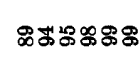 & ஜぶஃタタの \\
\hline & & $\begin{array}{l}\stackrel{0}{0} \\
0\end{array}$ & 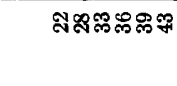 & 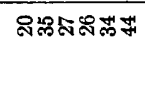 & 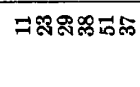 & พิสก์ & 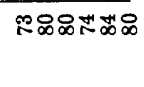 \\
\hline & & $\begin{array}{l}\text { \$艹 } \\
0 \\
0\end{array}$ & & & & 品品品 పేరత్ర & 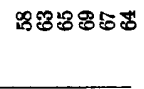 \\
\hline & & $\begin{array}{l}\text { §̊ } \\
0 \\
0\end{array}$ & 오꺼ニ오조 & 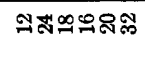 & 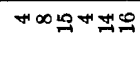 & ஜำ & 비 \\
\hline & \multirow{2}{*}{ 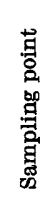 } & 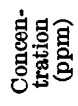 & $\begin{array}{l}\text { 야요 } \\
\text { - }\end{array}$ & 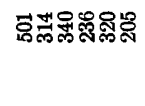 & 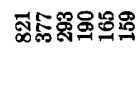 & 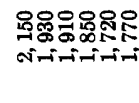 & 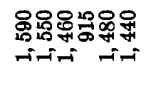 \\
\hline & & 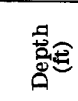 & 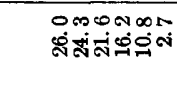 & 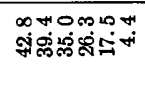 & 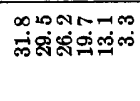 & 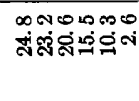 & 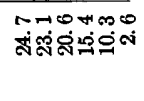 \\
\hline \multicolumn{3}{|c|}{ 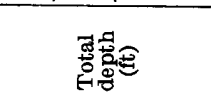 } & 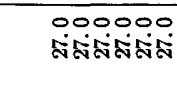 & 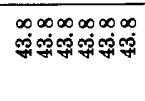 & 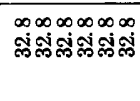 & 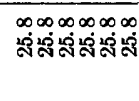 & 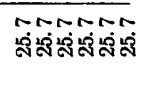 \\
\hline \multicolumn{3}{|c|}{ 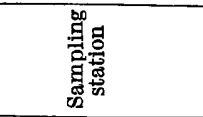 } & 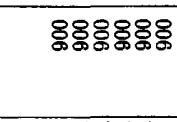 & 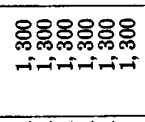 & 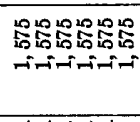 & క్రీ & 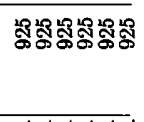 \\
\hline \multicolumn{3}{|c|}{ 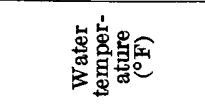 } & 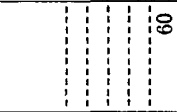 & 8 & : & & \\
\hline \multicolumn{3}{|c|}{ 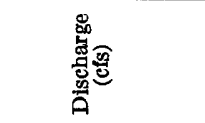 } & 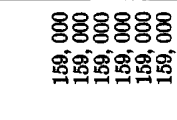 & 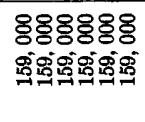 & 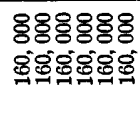 & 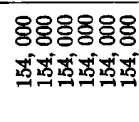 & 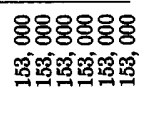 \\
\hline \multicolumn{3}{|c|}{ 茟 } & 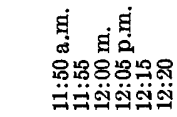 & 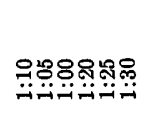 & 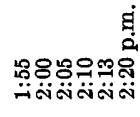 & 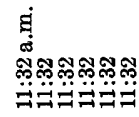 & 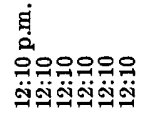 \\
\hline \multicolumn{3}{|c|}{ คึँ } & 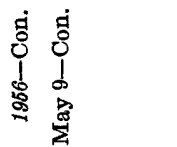 & & & 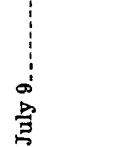 & \\
\hline
\end{tabular}




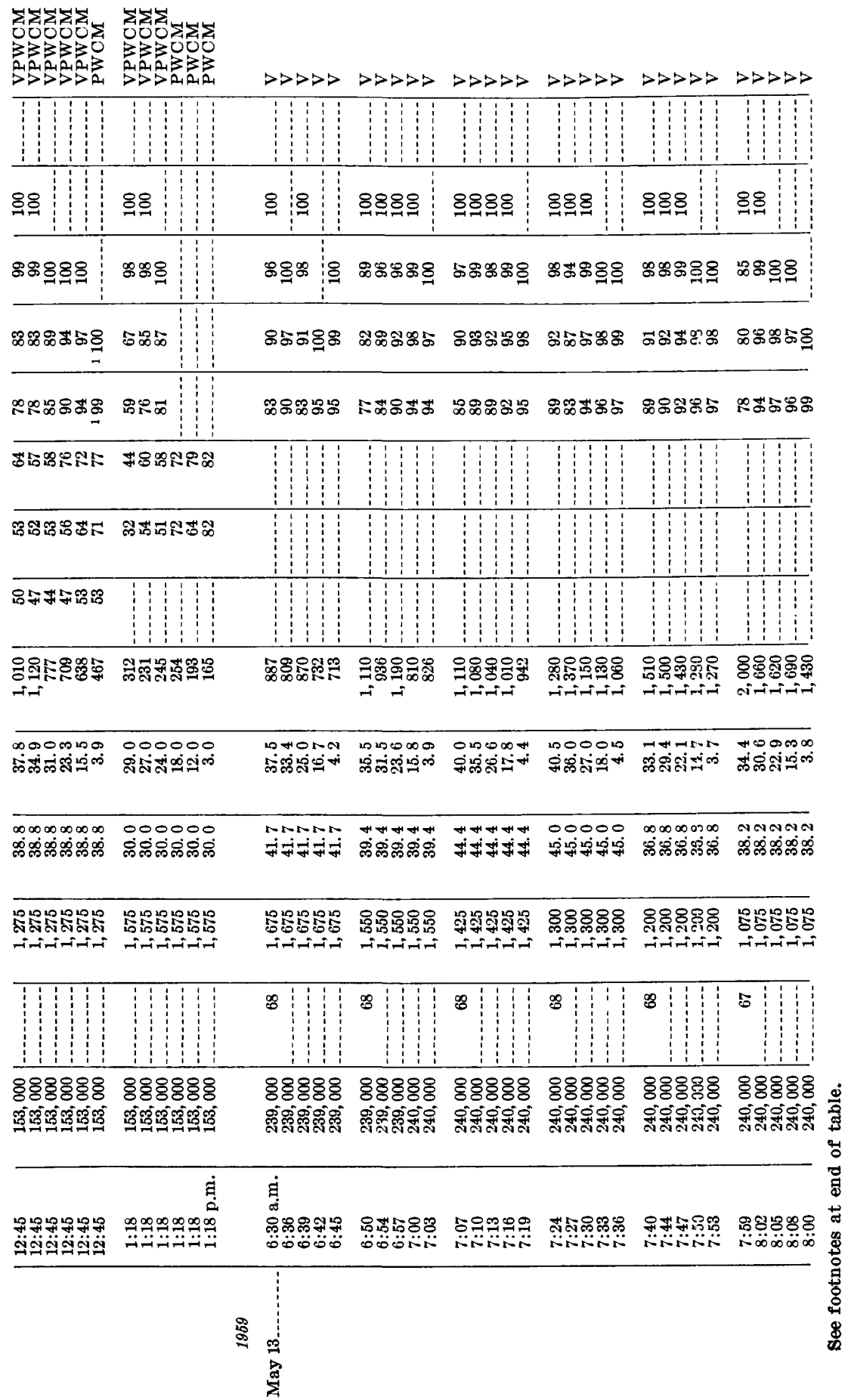




\begin{tabular}{|c|c|c|c|c|c|c|c|c|}
\hline \multicolumn{3}{|c|}{ 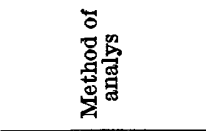 } & $\rightarrow \rightarrow$ & $\Rightarrow P D$ & $\Rightarrow P D$ & $\rightarrow \rightarrow>$ & $\rightarrow \rightarrow$ & $\Rightarrow \rightarrow$ \\
\hline \multirow{10}{*}{ 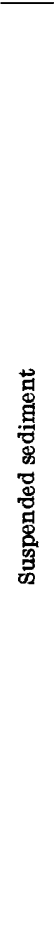 } & \multirow{8}{*}{ 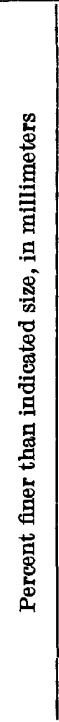 } & $\stackrel{8}{8}$ & & & & & : 1 & \\
\hline & & $\begin{array}{l}8 \\
8 \\
0 \\
0\end{array}$ & 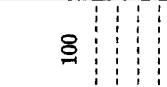 & 8 & 8 & & 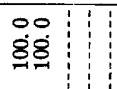 & \\
\hline & & $\begin{array}{l}0 \\
\text { : } \\
0\end{array}$ & ' & 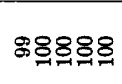 & 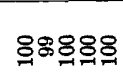 & 융్ㅇ్요 & 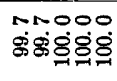 & 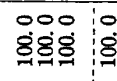 \\
\hline & & $\stackrel{\stackrel{3}{3}}{0}$ & 중잉요용 & 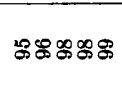 & 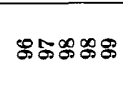 & পুஃ̊ & 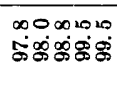 & 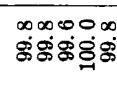 \\
\hline & & $\begin{array}{l}\text { §ै } \\
0 \\
0\end{array}$ & タஜガஐஃ & ガちちの゚ & 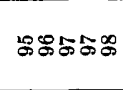 & ஜூஃஃஃ & 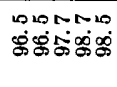 & 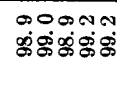 \\
\hline & & $\begin{array}{l}\stackrel{0}{0} \\
0 \\
\end{array}$ & & & & & & \\
\hline & & 范 & & & & & & \\
\hline & & ઠे & & & & & & \\
\hline & \multirow{2}{*}{ 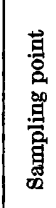 } & $\begin{array}{l}\text { 형모영 } \\
\text { 영형 }\end{array}$ & 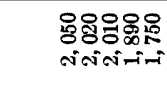 & 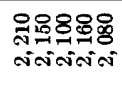 & 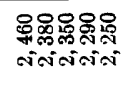 & 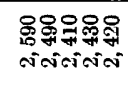 & 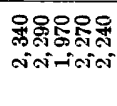 & $\begin{array}{l}\text { 울융워 } \\
\text { civivivivi }\end{array}$ \\
\hline & & 莕龟 & 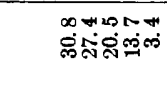 & 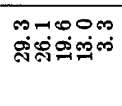 & 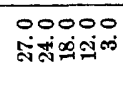 & 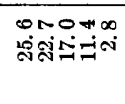 & 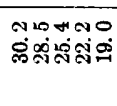 & 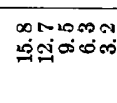 \\
\hline \multicolumn{3}{|c|}{ 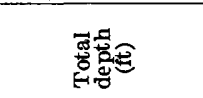 } & 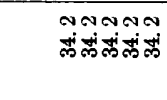 & 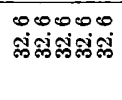 & 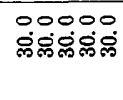 & म" & लंभिंलं & 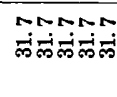 \\
\hline \multicolumn{3}{|c|}{ 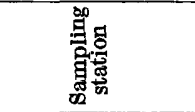 } & 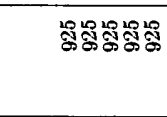 & 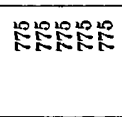 & 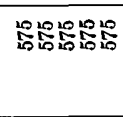 & 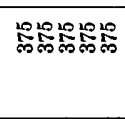 & ర్రిళ్రిళ్రిశ్రిశ్ర & 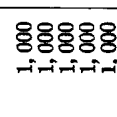 \\
\hline \multicolumn{3}{|c|}{ 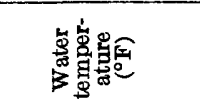 } & & & & 5 & & \\
\hline \multicolumn{3}{|c|}{ 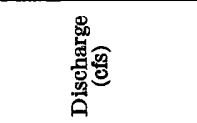 } & 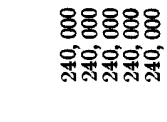 & 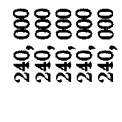 & 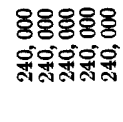 & 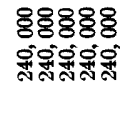 & 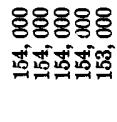 & 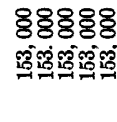 \\
\hline \multicolumn{3}{|c|}{$\stackrel{g}{\sharp}$} & 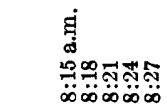 & 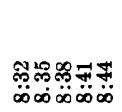 & 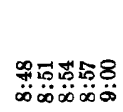 & 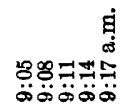 & 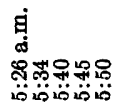 & 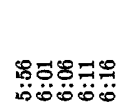 \\
\hline \multicolumn{3}{|c|}{ 苋 } & 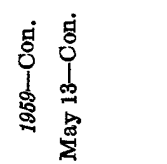 & & & & $\begin{array}{c}\vdots \\
\vdots \\
\vdots \\
\vdots \\
\vdots \\
\vdots\end{array}$ & \\
\hline
\end{tabular}




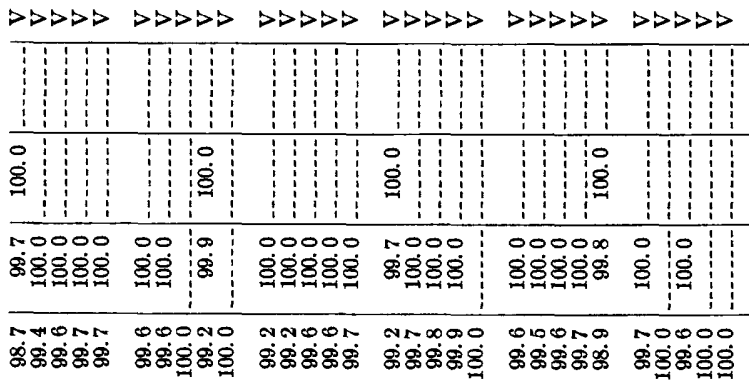

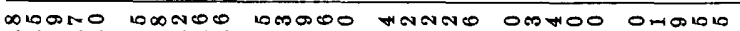

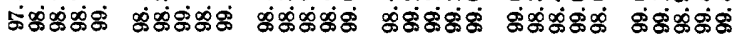

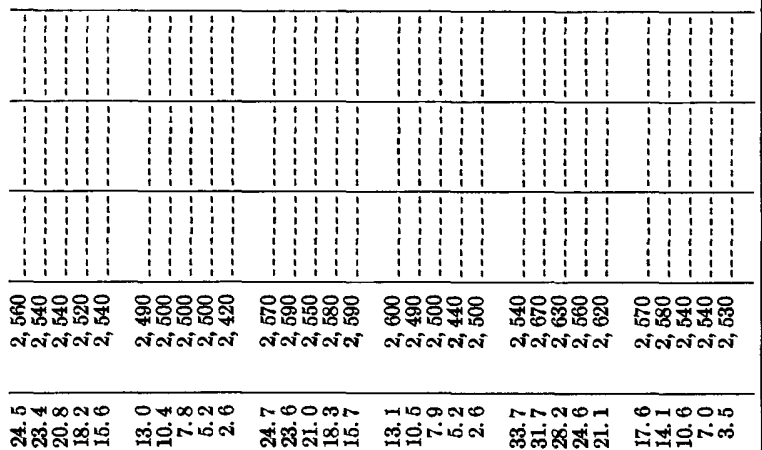

0000000000 NNNNN NNNNN NNNNN NNNNN

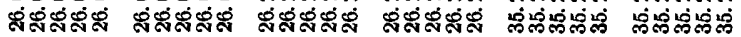

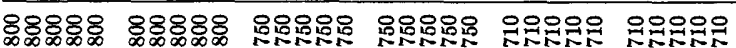

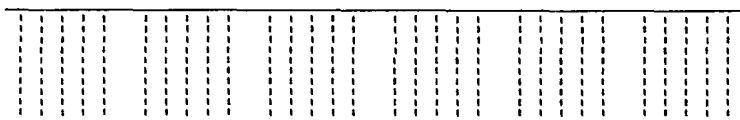

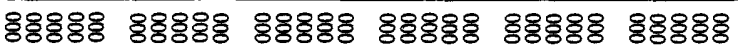

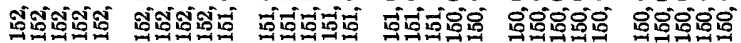


The average $z_{1}$ for a cross section and for a range of sand size was plotted against $w /\left(k u_{*}\right)$ to define the relationship (fig. 21) between

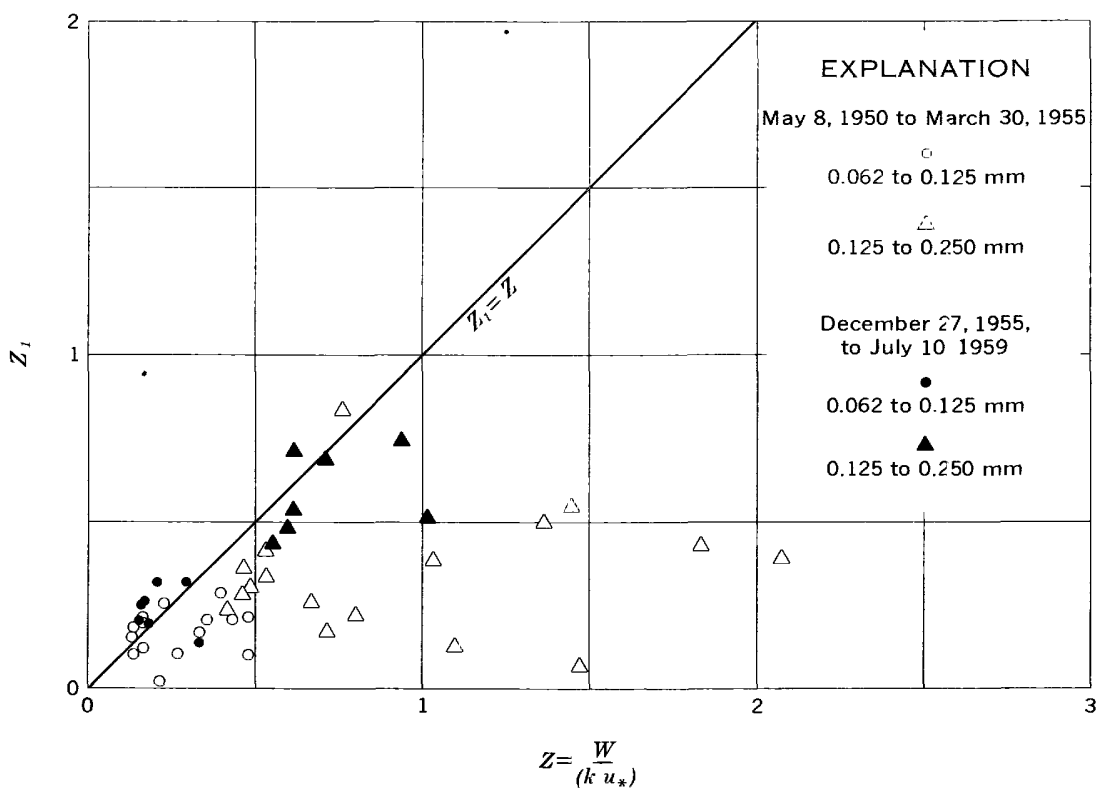

Figure 21. $-z_{1}$ as a function of $w /\left(k u_{*}\right)$.

$z_{1}$ and $z$. (A size range including both silt and clay is too wide to have a single representative fall velocity; so, the $z_{1}$ 's for the range of smallest sizes were not plotted.) The $z_{1}$ 's and $z$ 's through March 31, 1955 , were based, respectively, on size analyses of sands that were made with the bottom-withdrawal tube and on $k$ 's that were computed from the discharge measurements; they are less consistent than the $z_{1}$ 's and $z$ 's for later times. Although the points scatter widely in figure 21 , especially for the earlier determinations, the average of all the $z_{1}$ 's in table 6 for the size range from 0.062 to $0.125 \mathrm{~mm}$ is 0.20 , which compares reasonably well with the average $z$ of 0.27 . If based only on the seven determinations after March 31, 1955, the average $z_{1}$ and $z$ are 0.24 and 0.21 , respectively. Thus, for this size range the average $z_{1}$ is roughly the same as the average $z$. The ratio of the average $z_{1}$ for the size range from 0.125 to $0.250 \mathrm{~mm}$ to the average $z_{1}$ for the size range from 0.062 to $0.125 \mathrm{~mm}$ is $0.41 / 0.20$ (equal $2.0: 1.0$ ) for all the determinations or $0.59 / 0.24$ (equals $2.5: 1.0$ ) for the last seven determinations. The ratio of fall velocities of representative 
particles for the two size ranges varies with temperature but averages about $3.3: 1.0$. These fall velocities were based on equations given by Rubey (1933). Hence, the average $z_{1}$ 's for all the determinations indicate a variation of $z_{1}$ with about the 0.58 power of the fall velocity, and the average $z_{1}$ 's for the last seven determinations indicate a variation of $z_{1}$ with about the 0.77 power of the fall velocity. For some shallow streams in Nebraska, $z_{1}$ for sands varied with about the 0.7 power of fall velocities computed from Rubey's equations (Colby and Hembree, 1955, p. 70; Hubbell and Matejka, 1959, p. 72). Except for the difference between the theoretical variation and the actual variation of $z_{1}$ with changing fall velocity, the theoretical equation for the vertical distribution of sediment concentration se?ms to apply reasonably well for the Mississippi River at St. Louis.

The relationship (fig. 21) of $z_{1}$ to $w /\left(k u_{*}\right)$ for the def $n$ flows over rough beds at St. Louis seems to be generally similar and about as good as the relationship that was reported by Einstein and Chien (1954, p. 3 and fig. 1) for flows over a plane bed in the Missouri River at Omaha. That is, the $z_{1}$ 's and $z$ 's are approximately equal for low $z$ 's, but the $z_{1}$ 's do not increase nearly so fast as the $z$ 's. In general, $z_{1}$ seems to be the same function of $w /\left(k u_{*}\right) \mathrm{fc}^{\boldsymbol{r}}$ deep flows over dune beds as for flows over plane beds. However, this conclusion is inconsistent with the suggestion by Einstein $(1950$, p. 28 , 59) that $z$ be computed from the equation $z=w /\left(0.4 n u_{*}{ }^{\prime}\right)$. The difference between $w /\left(0.40 u_{*}{ }^{\prime}\right)$ and $w /\left(k u_{*}\right)$ is large at St. Louis. As $k$ averaged about 0.34 and the ratio of $u_{*}{ }^{\prime}$ to $u_{*}$ for the 10 determinations in table 3 averaged 0.46 , the $z$ 's computed according to Einstein's equation might be about $0.34 /(0.40)(0.46)$ or roughly 1.8 times as large as those that were computed from $w /\left(k u_{*}\right)$. Vanoni and Brooks (1957, p. 73-75) noted that the observed vertical distributions of sediment over dune beds in certain laboratory experiments were inconsistent with any decrease in $u_{*}$ such as Einstein suggested. A recent reexamination of Einstein's derivation of the equation for $z$ indicates that the classical equation $z=w /\left(k u_{*}\right)$ probably should have been obtained for flow over dune beds as well as for flow over plane beds. Although the basic assumptions on which the derivation is based do not apply accurately for flow over dune beds, the only obvious change in the equation for $z$ for flow over dune beds as compared with flow over plane beds is that the $k$ for widely spaced major roughness elements, such as dunes, may not be a true turbulence constant.

\section{BEDLOAD DISCHARGE AND BED-MATERIAL DISCHARGE}

Samples obtained with samplers currently available for practical field use can be used to determine the sediment discharge in the zone 
traversed by the sampler or the size distribution of the material in the bed, but they cannot be used to determine the discharge of material on the bed or in close proximity to the bed. No samplers are as yet available that will measure the bedload discharge or the total sediment discharge in a natural stream. In various rivers the measured suspended-sediment discharge probably ranges from about 40 percent to nearly 100 percent of the total sediment discharge. The bed-material discharge affects the stage-discharge relation hip and builds bars that may obstruct the channel for navigation; so it is a significant part of the sediment discharge even though it may be a fairly small percentage of the total. Therefore, the relation of bed-material discharge to velocity and temperature was studied, and several different equations were used to compute bedload discharge and bed-material discharge.

Because the bed-material discharge consists of particles of the same size as those present in significant quantities in the bed, the size distributions of samples from the bed were examined to determine the sizes that are part of the bed-material discharge. On the average, the bed-material samples had very small amounts of material finer than $0.125 \mathrm{~mm}$. Therefore, the bed-material discharge is considered in this report to be the rate of transport of all particles larger than $0.125 \mathrm{~mm}$, regardless of the mode of transport.

The measured bed-material discharge (see "Definitions") is computed from the measured concentration of particles larger th an 0.125 $\mathrm{mm}$ in the sampled zone and the streamflow for the whole cross section. Therefore, it includes all the bed-material discharge in the sampled zone and part of the bed-material discharge in the unsampled zone. The measured bed-material discharge was closely related to the mean velocity and to the water temperature (fig. 22). The measured bed-material discharge increased with about the fourth power of the mean velocity; and, for a given mean velocity, the high discharges were associated with low water temperatures.

Several different equations were used to compute bedload discharges and bed-material discharges, and the results are shown in table 8. For most of the computations, the hydraulic data and sediment data were obtained from measurements made within a 3-day period and are considered to be concurrent. For the other computations, hydraulic data were obtained from rating curves of discharge, depth, and velocity plotted against gage height. The results were studied to determine the equations that are best suited for application to this river and to similar rivers.

Because an accurate measurement of bedload discharge or total bed-material discharge is not possible, an absolute determination of 


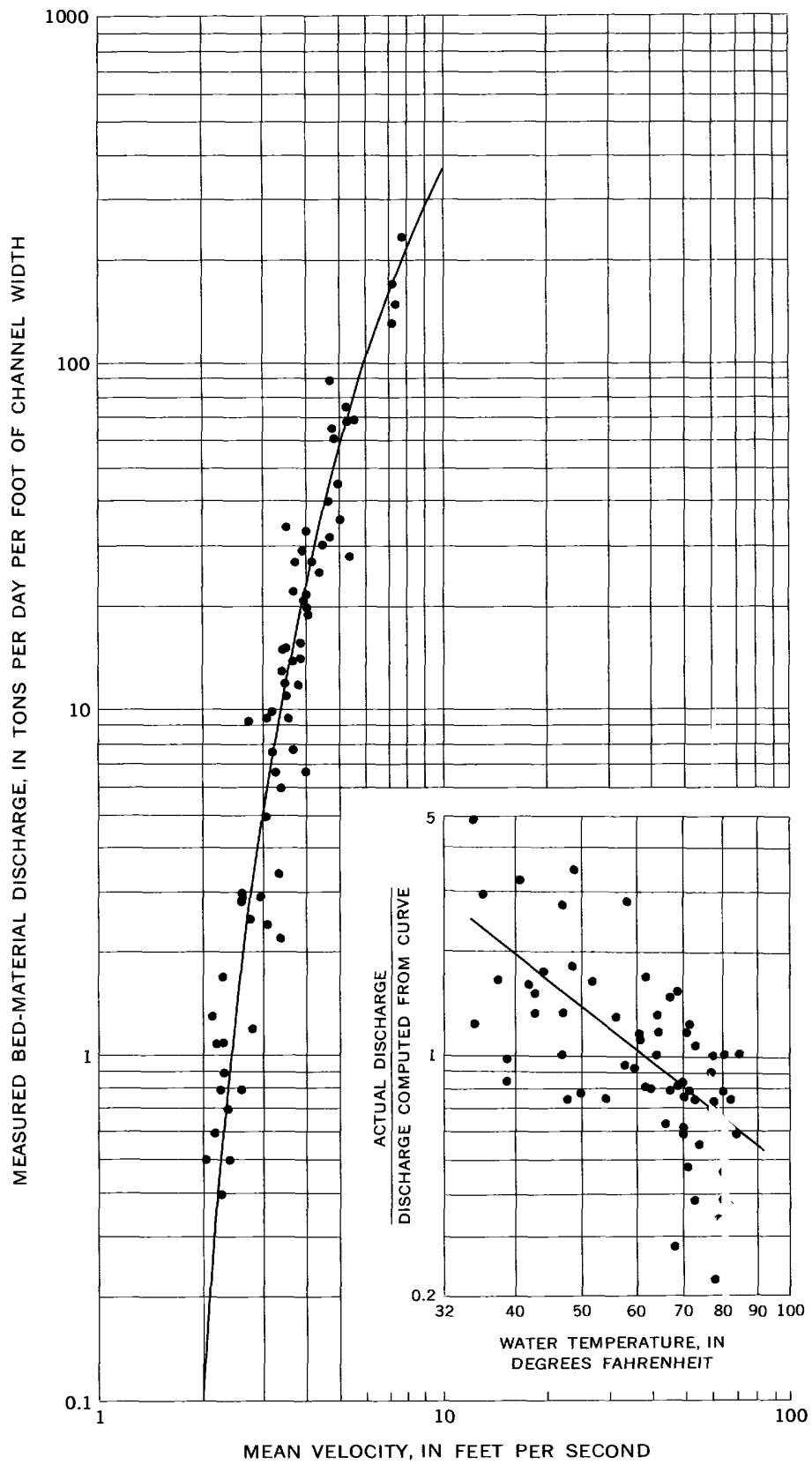

Figure 22.-Relation of measured bed-material discharge to mean velocity and water temperature. 


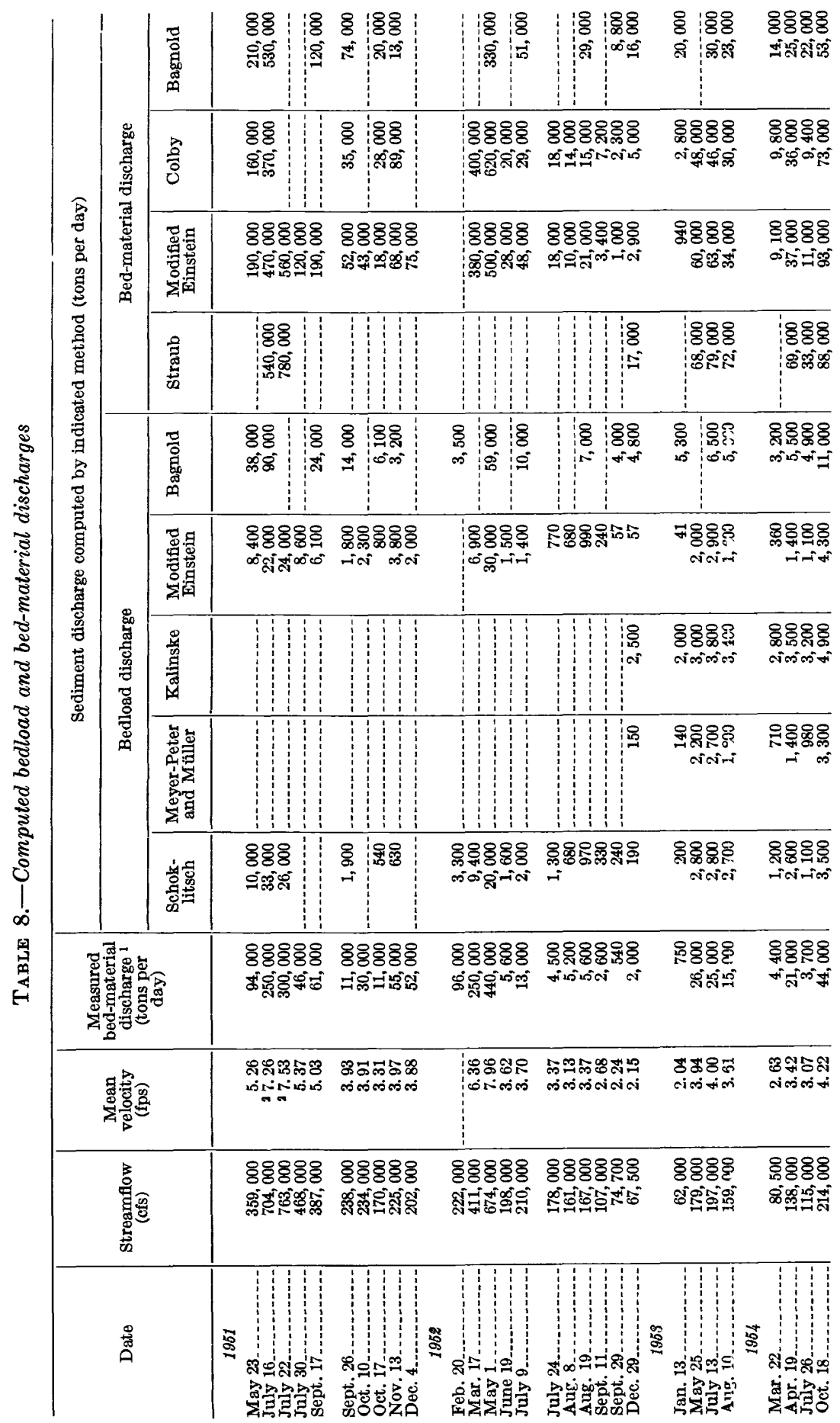




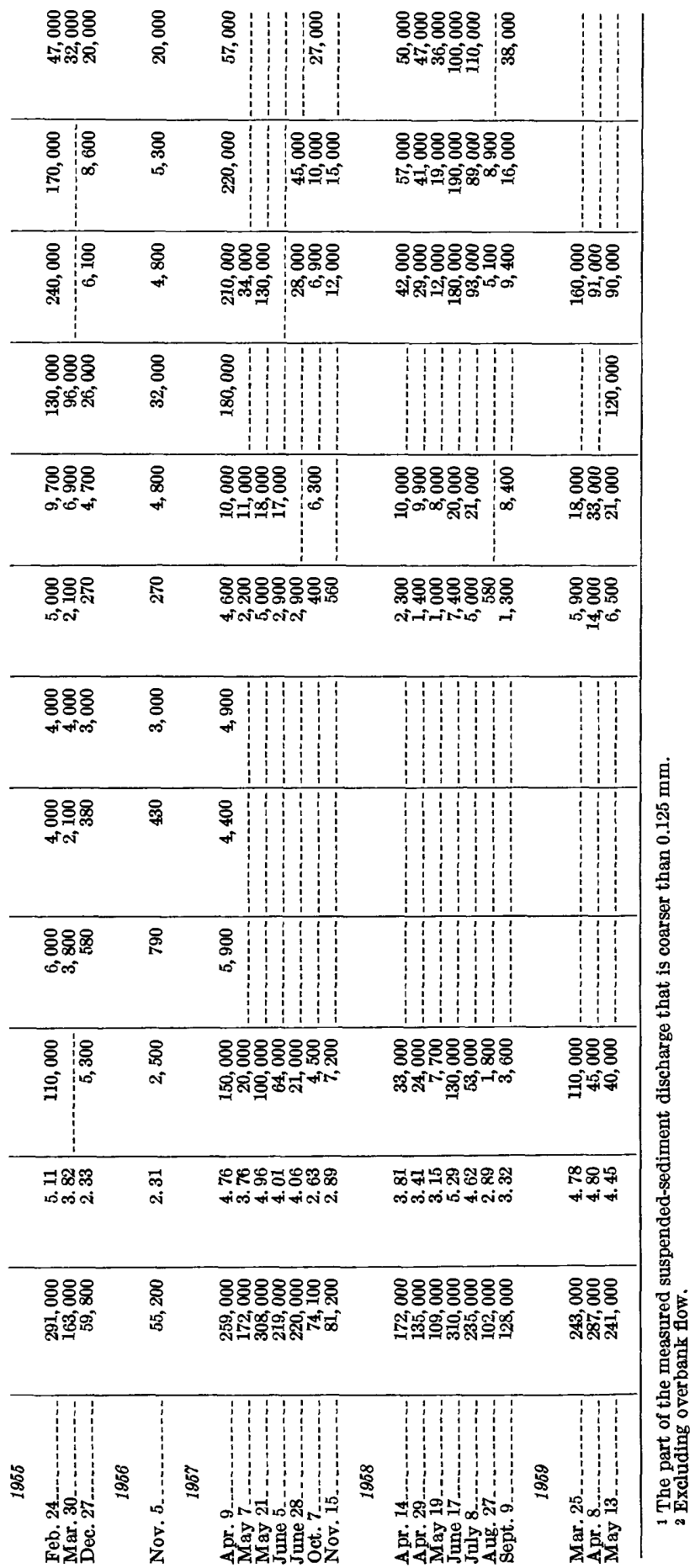


the accuracy of an equation cannot be made. Indirect methods of evaluating the equations must be used. The measurable quantity that is probably most closely related to the bedload discharge and to the total bed-material discharge is the measured part of the bed-material discharge. This quantity was used as the primary means of evaluating the results of the different equations.

Measurements in rivers that have natural contractions or artificial turbulence flumes where the total sediment discharge is in suspension have shown that the bed-material discharge is closely related to the mean velocity in a normal section of the river. The bed-material discharge varies with about the third power of the mean velocity. Therefore, the mean velocity was used as a secondary means of evaluating the results of the equations.

Bedload discharges were computed with the Schoklitsch, the Meyer-Peter and Müller, the Kalinske, the modified Einstein, and the Bagnold methods.

Schoklitsch's equation (Shulits, 1935) expresses the bedload discharge as a function of the particle diameter, the slope, the streamflow, and a critical discharge that depends on the particle diameter:

$$
g_{b}=\frac{86.7}{\sqrt{12 d}} S_{e}^{3 / 2}\left(q-0.00532 \frac{12 d}{S_{e}^{4 / 3}}\right)
$$

where

$q_{b}$ is bedload discharge, in pounds per second per foot of width

$d$ is particle diameter, in feet

$S_{e}$ is "hydraulic slope," presumably the slope of the energy grad" int

$q$ is streamflow, in cubic feet per second per foot of width

The equation can be used to compute the bedload discharges by ranges of particle size. Bedload discharges computed for the whole width with Schoklitsch's equation and converted to tons per day are shown plotted against the measured bed-material discharge in figure $23 \mathrm{~A}$. The dashed lines in figure 23 are lines of equality and are shown, not to imply that the computed bedload discharge should be equal to the measured discharge of particles larger than $0.125 \mathrm{~mm}$, but to indicate the relative magnitudes of the two discharges. The bedload discharges increased with about the 0.8 power of the measured bed-material discharge and with about the fourth power of the mean velocity.

Meyer-Peter and Müller's equation (1948) for bedload discharge in wide channels with negligible influence from the banks can be 


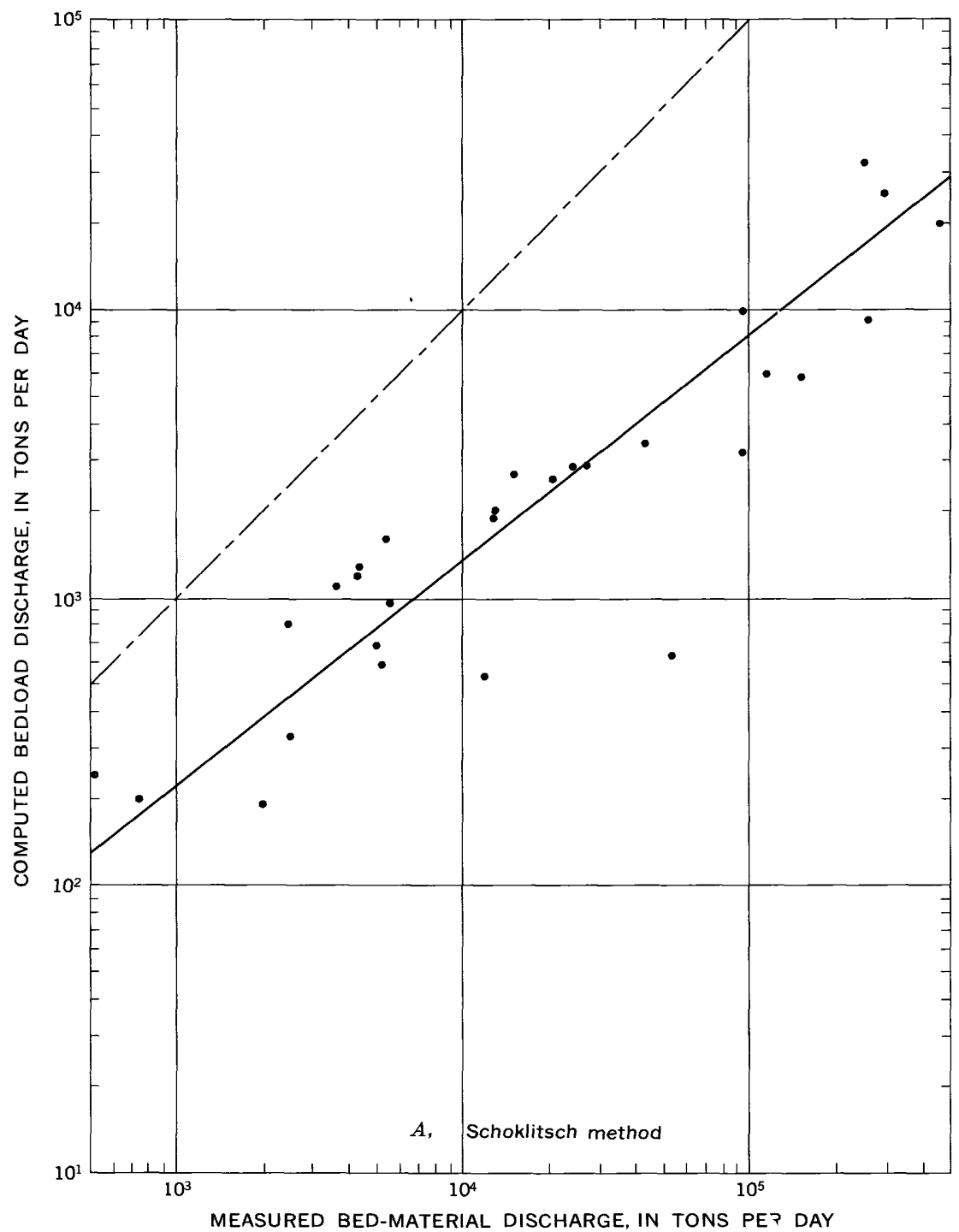

Figure 23.-Bedload discharges computed by various methods. $A$, Schoklitsch method; $B$, Meyer-Peter and Müller method; $C$, Kalinske method; $D$, modified Einstein method; $E$, Bagnold method. ( $B-E$ on following pages.)

written for units of meters, metric tons, and seconds as

$$
\gamma\left(\frac{k_{t}}{k_{r}}\right)^{3 / 2} \bar{y}_{0} S_{e}=0.047\left(\gamma_{s}-\gamma\right) d_{e}+0.25\left(\frac{\gamma}{g}\right)^{1 / 3}\left(\frac{\gamma_{s}-\gamma}{\gamma_{s}}\right)^{2 / 3} q_{b}^{2 / 3}
$$

where

$\gamma \quad$ is specific weight of water, in metric tons per cubic meter

$k_{t} \quad$ is equal to $\pi / y_{0}^{2 / 3} S_{e}^{1 / 2}$, a discharge coefficient 


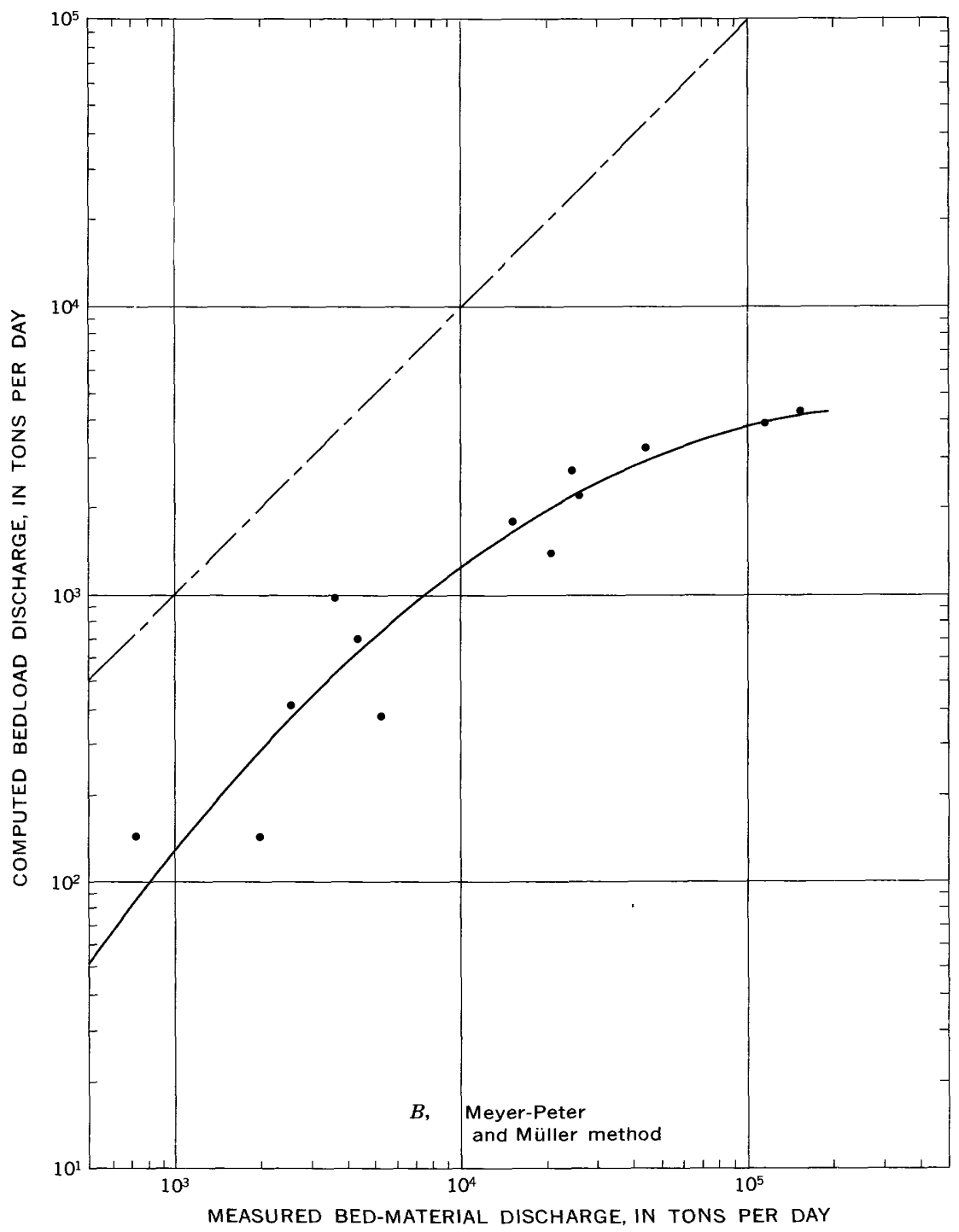

$k_{r}$ is equal to $26 /\left(d_{90}\right)^{1 / 6}$, an approximation of the maximum discharge coefficient that would occur with bed material of a giver size and a plane bed with no bed-material movement

$d_{9_{0}}$ is the particle size, in meters, at which 90 percent of the bed material by weight is finer

$\gamma_{s}$ is specific weight of the sediment, in metric tons per cubic meter

$d_{e}$ is effective diameter of bed material, in meters

$q_{b}$ is bedload discharge, in metric tons per second per meter of width

The ratio $k_{t} / k_{r}$ depends on the form of the bed; so the equation is one of the few that account for the effects of bed forms on the bedload 


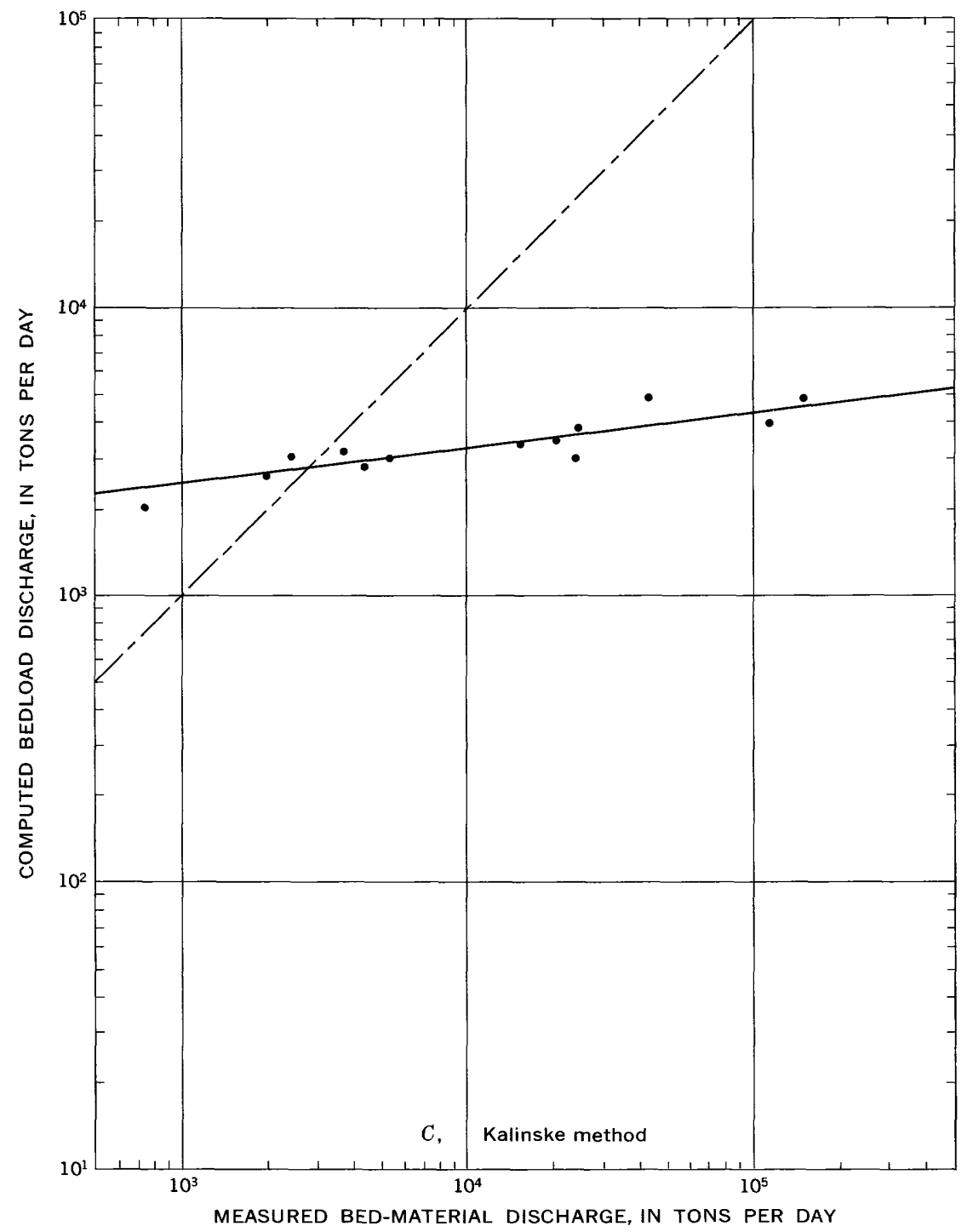

discharge. The equation can be used to compute bedload discharge by ranges of particle size. Bedload discharges computed for the whole width from this equation and converted to tons per day are shown plotted against measured bed-material discharge in figure $23 B$. Bedload discharges increased with about the first power of the measured bed-material discharge for low and medium cischarges and with about the one-third power for high discharges. Bedload discharges increased with about the fourth power of the mean velocity. 


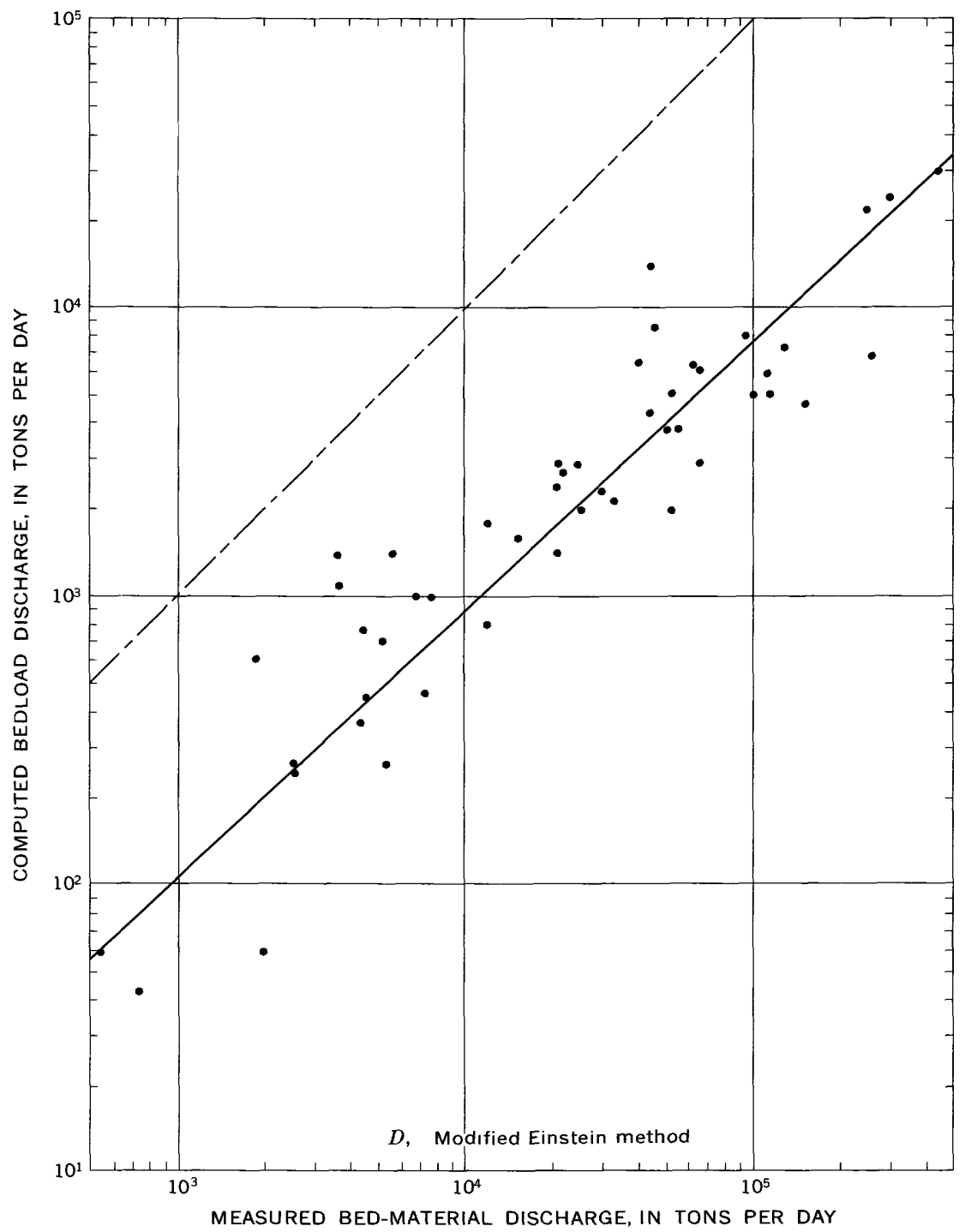

Kalinske's equation (1947) is used for computing bedload discharges by ranges of particle size. The equation can be written

where

$$
q_{b}=u_{* \gamma_{s}} d_{i} p_{i} 7.3 \frac{\bar{U}_{g}}{\bar{U}}
$$

$q_{b} \quad$ is bedload discharge of a size range, in pounds per second per foot of width

$u * \quad$ is shear velocity, in feet per second 


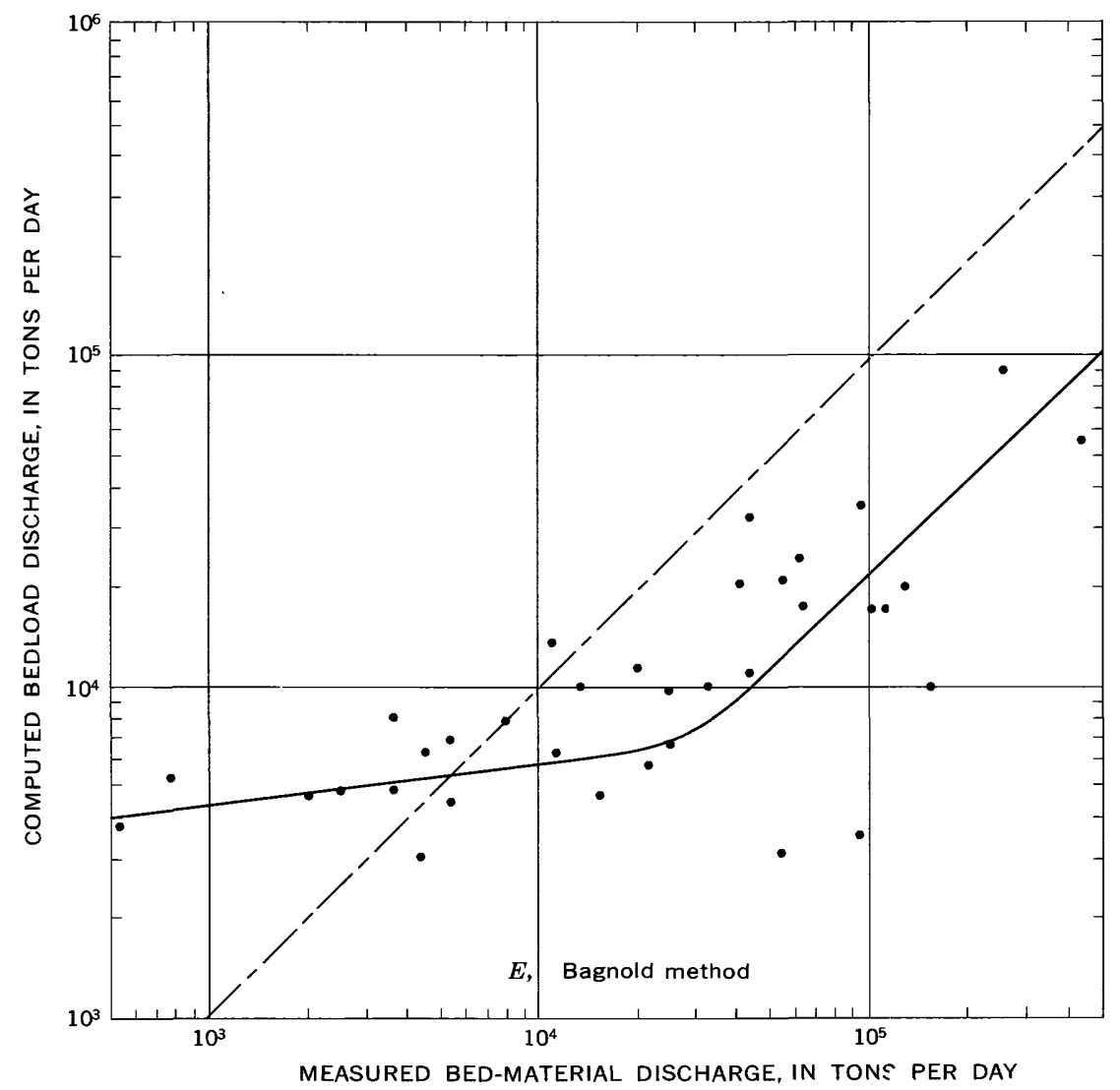

$\gamma_{s}$ is specific weight of sediment, in pounds per cubic foot

$d_{i} \quad$ is geometric mean diameter of a size fraction of bed material, in feet $\underline{p_{i}}$ is the fraction of bed area occupied by the particles in a size range $\bar{U}_{g} / \bar{U}$ is the ratio of mean speed of movement of the grains to mean fluid velocity at the grain level

The factor $\bar{U}_{\mathrm{g}} / \bar{U}$ depends on the relative intensity of turbulence and on the relative bed-shear stress. Bedload discharges were computed for the whole width and converted to tons per day. In figure $23 \mathrm{C}$, bedload discharges increased with only the 0.13 power of the measured bed-material discharge. The bedload discharges increased with only the first power of the mean velocity.

The modified Einstein procedure (Colby and Hembree, 1955) can be used to compute bedload discharge, bed-material discharge, and total sediment discharge. In the procedure is used a maximum amount of measured data, which include suspended-sediment concentration, particle-size distribution, mean velocity, and temperature. Bedload discharges increased with about the 0.95 power of the 
measured bed-material discharge (fig. $23 D$ ) and with about the fourth power of the mean velocity.

Bagnold (1956, p. 250 ) defined the material composing "bed load" as "that part of the load whose normal immersed weight component is in normal equilibrium with the grain stress $* * *$ This stress is transmitted downwards via the dispersed grains to the stationary grains of the bed upon which it therefore ultimately rests." Thus the bedload discharges computed by Bagnold's equations may include some material that would be in suspension and that might be sampled by suspended-sediment samplers. For the particular conditions of the Mississippi River at St. Louis, Bagnold's fquations can be simplified to

where

$$
g_{\mathrm{b}}=5,100 B\left(y_{0} S\right)^{3 / 2}
$$

$g_{b}$ is "bed load" discharge, in pounds per second per foot of width

$B$ is a mathematical abbreviation for a group of parameters that depend on the particle size

$y_{0}$ is depth of flow, in feet

$S$ is slope of the bed surface, assumed to be the same as the slope of the water surface for a 6.5-mile reach

Bedload discharges were computed for the whole width and converted to tons per day. They were nearly constant at low and medium discharges and increased with about the first power of the measured bed-material discharge at high discharges (fig. 23E). They increased with about the third power of the mean velocity.

Bed-material discharges have been computed using Straul's equation, the modified Einstein procedure, and Bagnold's metlod, and by adding the unmeasured sediment discharge computed with Colby's method to the measured bed-material discharge.

Straub's equation (U.S. Congress, 1935) is intended for computing "bed load." However, because $\tau_{c}$ and $\Theta$ for the equation were determined from data for bed-material discharge and because sediment discharges computed with the equation are about the same in magnitude as those computed with other methods for bed-material discharge, the results are regarded as bed-material discharges rather than bedload discharges. The equation can be written as

where

$$
q_{B M}=\boldsymbol{\theta} y_{0} S_{e}\left(y_{0} S_{e}-\frac{\tau_{c}}{\gamma}\right)
$$

$q_{B M}$ is bed-material discharge, in pounds per second per foot of width

$\theta$ is the sediment characteristic

$y_{0}$ is the depth of flow, in feet 


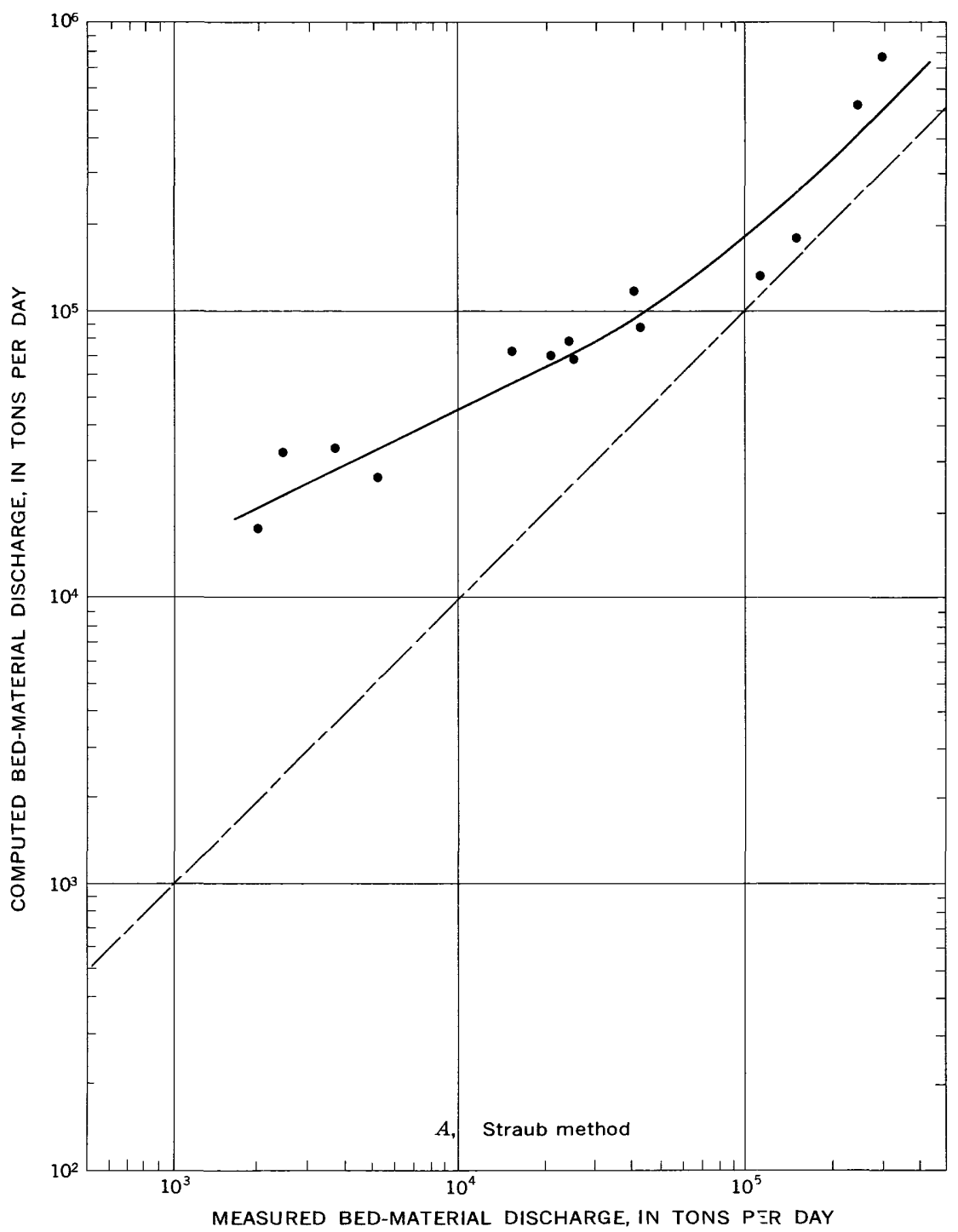

Figure 24.-Bed-material discharges computed by various methods. $A$, Straub method; $B$, modified Einstein method; $C$, Colby method; $D$, Ragnold method. ( $B-D$ on following pages.)

$\tau_{c}$ is the transporting force required to start movement of the bed material, in pounds per square foot

$\gamma$ is the specific weight of water, in pounds per cubic foct

Bed-material discharges computed for the whole width with Straub's equation and converted to tons per day are shown plotted against measured bed-material discharge in figure $24 A$. The dashed lines in figure 24, as in figure 23, are lines of equality. Computed bed-material 


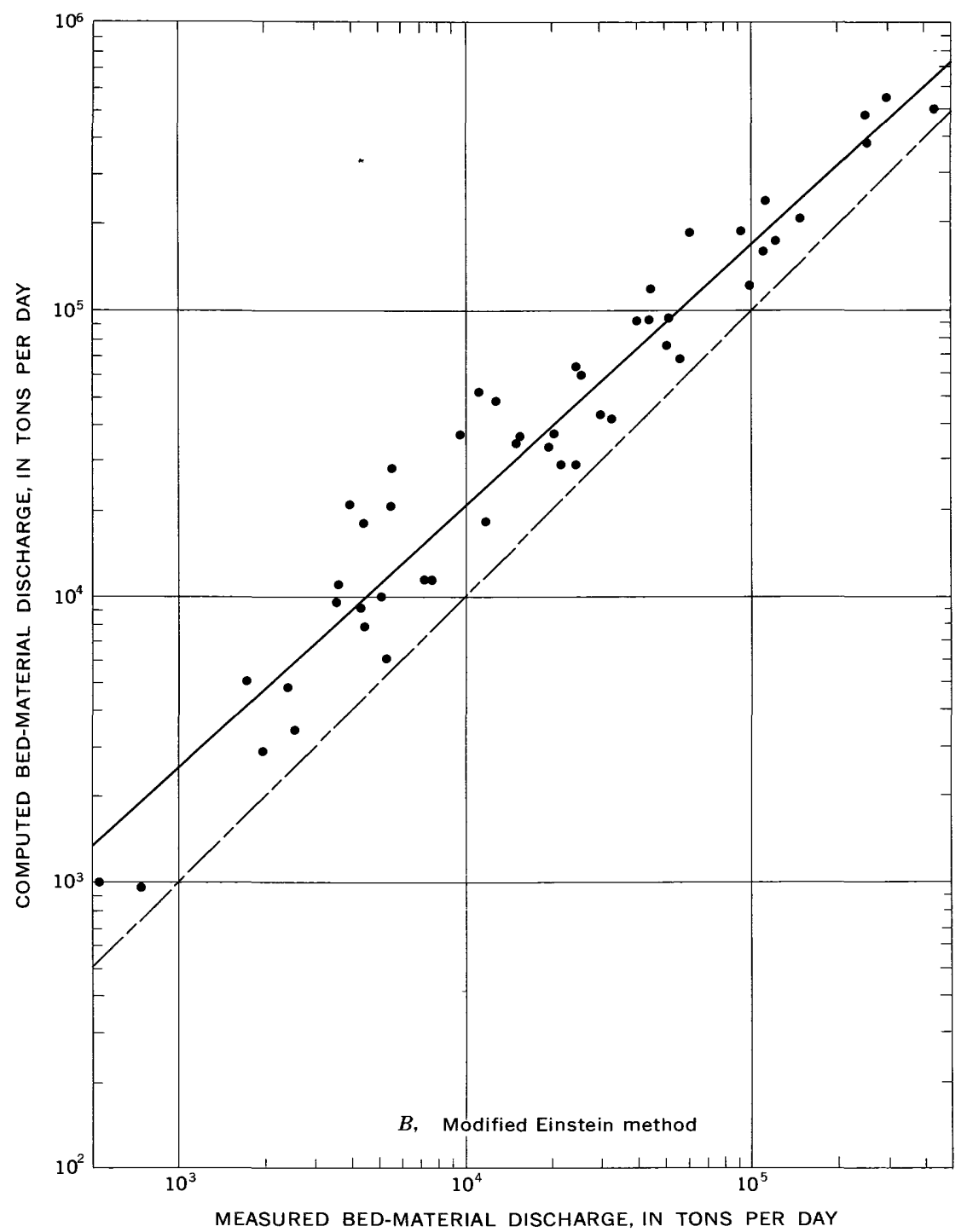

discharge will not be less than the measured bed-material discharge unless one or both of the discharges are in error. The discharges from Straub's equation increased with only the one-half power of measured bed-material discharge at low discharges and with about the first power at high discharges. They increased with about the third power of the mean velocity.

Bed-material discharges computed with the modified Einstein procedure (Colby and Hembree, 1955) increased with the 0.9 power of the measured bed-material discharge (fig. 24B). The scatter of 


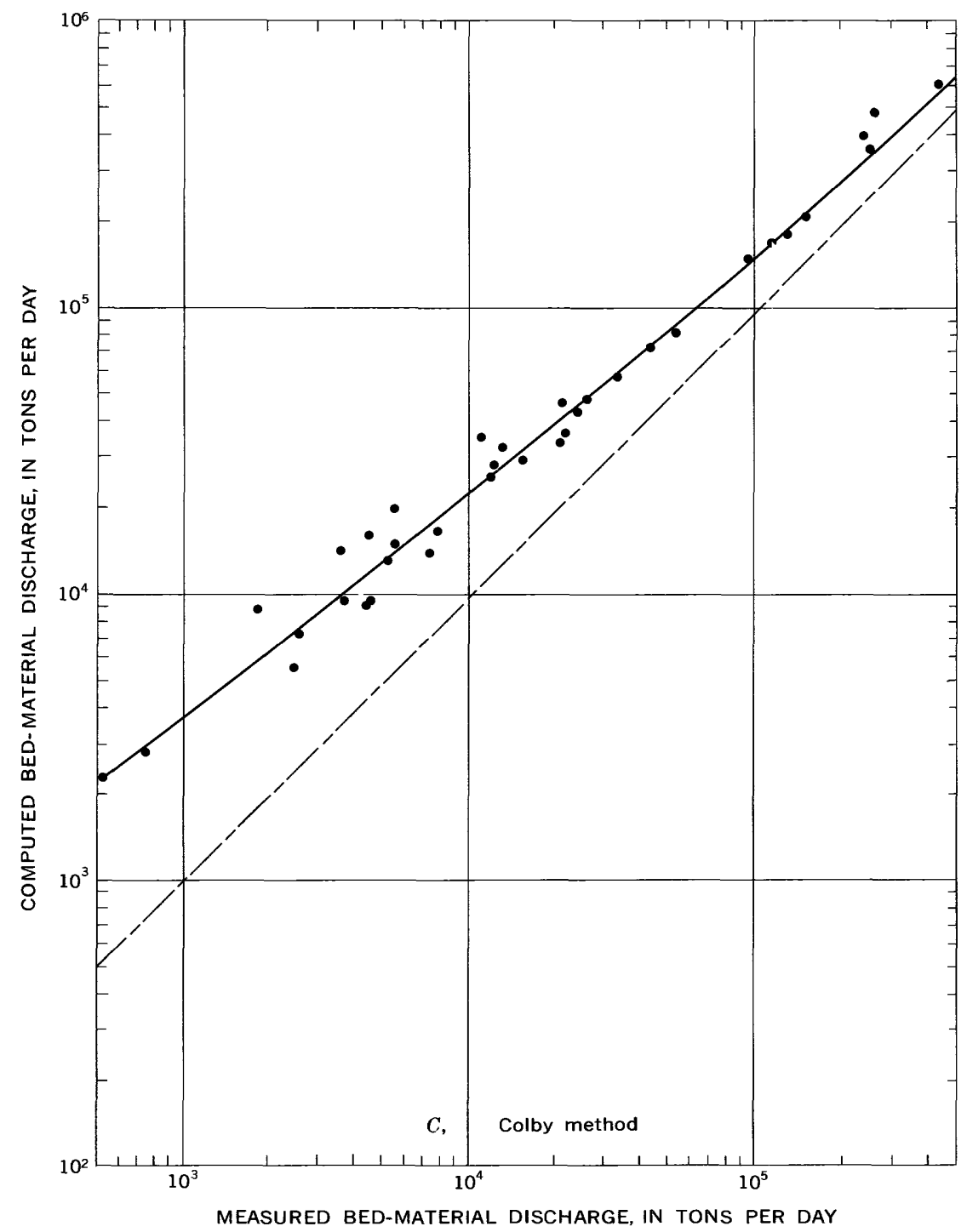

points is not excessive. The bed-material discharges increased with about the fifth power of the mean velocity.

Colby (1957) presented a method for computing unmeasured sediment discharge from the relation to mean velocity, depth, and concentration of suspended sands. Total bed-material discharges can be computed by adding the unmeasured sediment discharge to the measured bed-material discharge. The bed-material discharges increased with about the three-fourths power of the measured bed- 


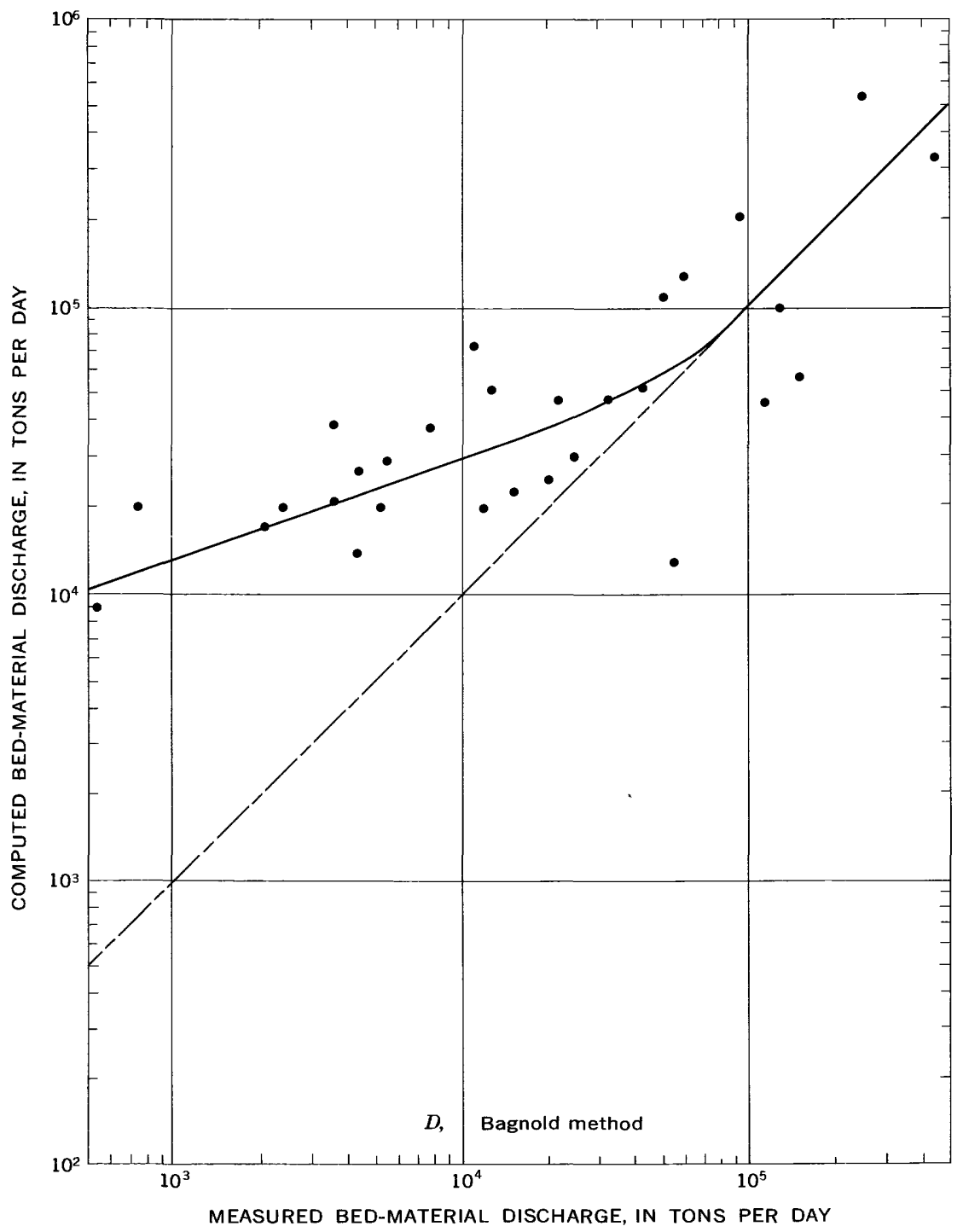

material discharge (fig. $24 \mathrm{C}$ ) and with about the fourth power of the mean velocity.

Bagnold (1956) gave functions for "total transport rate." This term was interpreted to be the total transport rate of particle sizes that are in the bed, and it should be comparable to the bed-material discharge that was computed by other methods. Bed-material discharges from Bagnold's functions increased with about the one-half power of the measured bed-material discharge for low discharres and with the first power for high discharges (fig. 24D). For high dis- 
charges, the bed-material discharges from Bagnold's functions were about equal to the measured bed-material discharges. whereas in reality the total bed-material discharge must be greater than the measured part of the bed-material discharge.

For comparison of the results obtained with the different equations, the average curves from figures 23 and 24 were plotted together in figures 25 and 26 , respectively. The equality lines are also shown.

Figure 25 shows that the Schoklitsch equation and the modified Einstein procedure gave about the same results for bedload discharge. The Meyer-Peter and Müller equation also gave similar results except at high discharge, where it gave lower bedload discharges than the other two equations. The Kalinske equation gave bedload discharges that are not in agreement with the results of any other equation. Kalinske bedload discharges increased very slowly with measured bed-material discharge; therefore, this equation is probably not suited for application to rivers similar to the Mississippi. Because Bagnold's definition of "bed load" is different from that for the other equations, the results are not in agreement with those from any of the other equations.

This study indicates that the modified Einstein, the Schoklitsch, and the Meyer-Peter and Müller bedload methods are the most suitable for the Mississippi River and similar rivers.

Figure 26 shows that the bed-material discharges computed by the modified Einstein method and those determined by adding the unmeasured sediment discharge from Colby's procedure to the measured bed-material discharge are in very good agreement. The figure indicates that the results are logical and reasonable; the computed discharges are greater than the measured discharges, and they increase at a slightly slower rate than the measured discharges. The Straub equation gives results that are higher than those for the modified Einstein and the Colby methods in the low range and are about the same in the high range. Bed-material disnharges from Bagnold's functions are similar to those computed fom Straub's equation, but on the average they are about equal to the measured bed-material discharge in the high range.

This study indicates that, when the required data-such as measured velocities, concentrations, and particle-size distributions-are available, the most suitable methods of computing bed-material discharge for the Mississippi River and similar rivers are the modified Einstein method and the addition of the unmeasured sediment discharge from Colby's procedure to the measured bed-material discharge. When such data are not available, the Straub equation is the best method to use; but it probably will give results that are too high in the low range. 


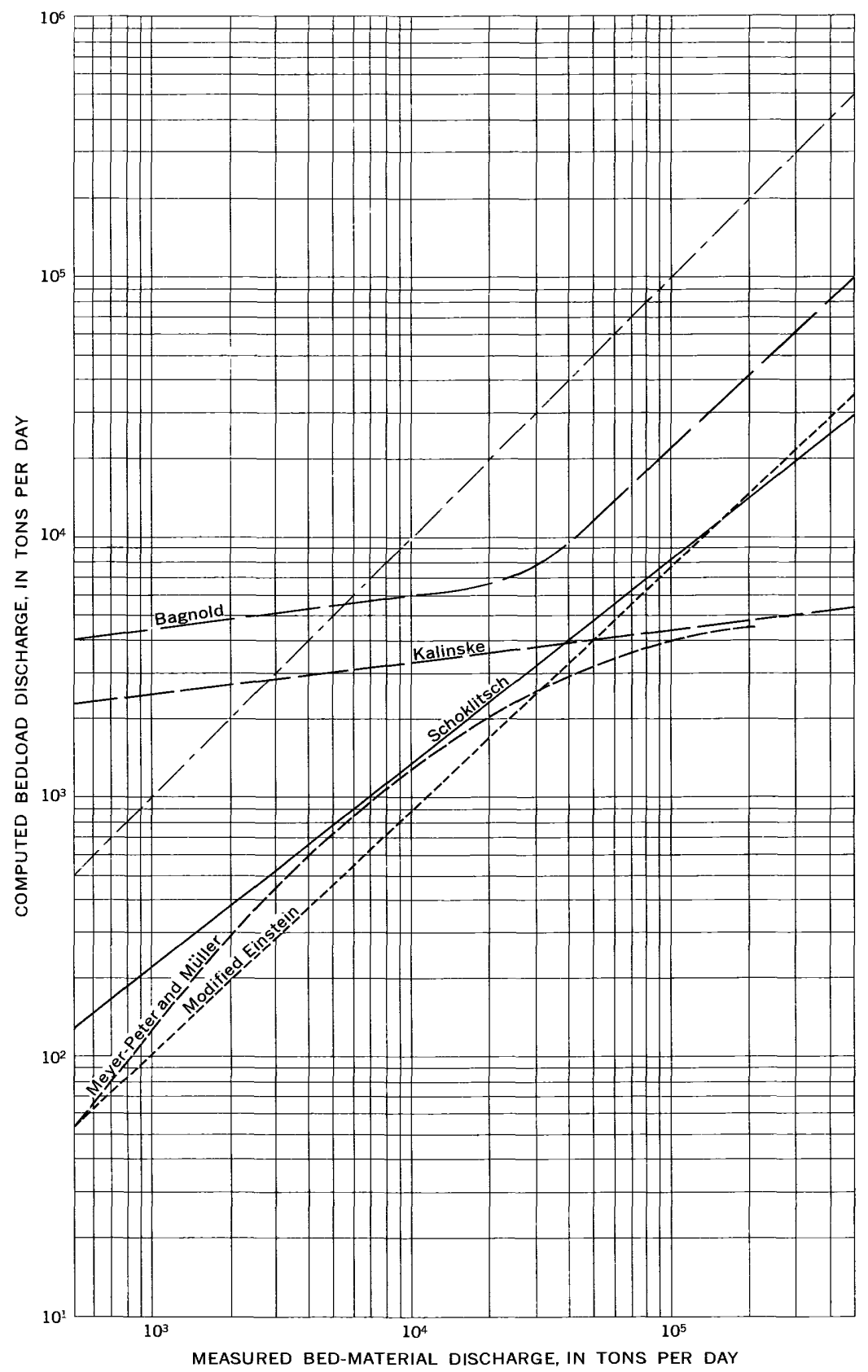

Figure 25.-Comparison of results from different methods of computing bedload discharge. 


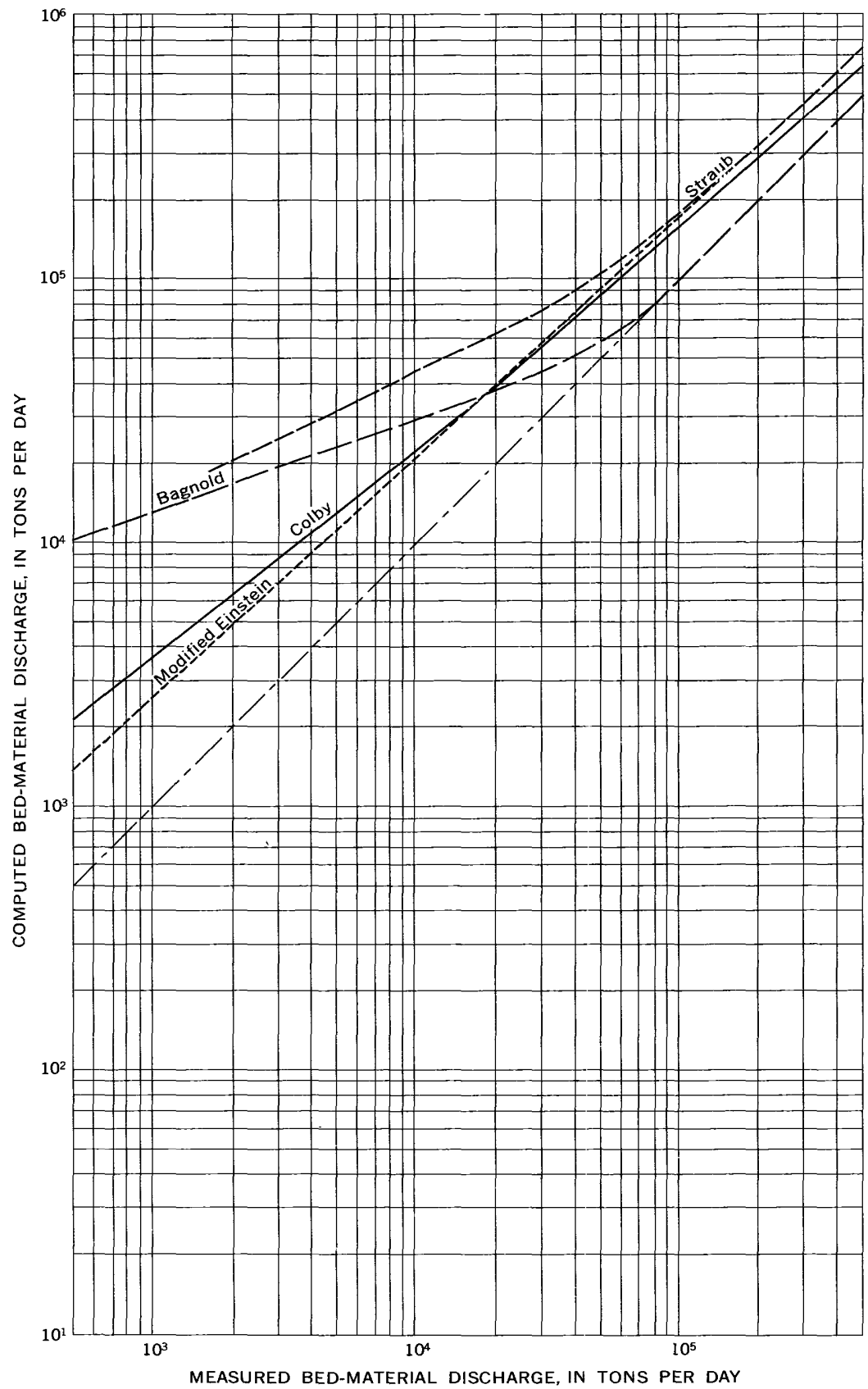

FiguRe 26.-Comparison of results from different methods of computing bed-material discharge. 
As an example of the relative magnitudes of measured surpendedsediment discharges and total sediment discharges that could be expected over fairly long periods of time, bed-material discharges and total sediment discharges were computed for the 1958 water year. The year 1958 was chosen both because conditions during that year represent those after most of the dams on the Missouri River main stem had been closed and because the mean flow of 145,000 cfs was fairly close to the long-term mean of $175,000 \mathrm{cfs}$. Rating curves of mean depth, mean velocity, and width were prepared from the weekly discharge measurements. For each day on which no c'ischarge measurement was made, the depth, velocity, and width were determined from these curves. Water temperatures were measured or estimated for each day. These depths, velocities, widths, and water temperatures were used with figure 22 to compute the bed-material discharge in the sampled zone. These bed-material discharges were expressed as concentrations by dividing by the streamflow and by the units-conversion constant 0.0027. The unmeasured sediment discharge was then computed by Colby's method (1957).

These computations resulted in an unmeasured sediment cischarge of $5,800,000$ tons and a total sediment discharge of $114,000,000$ tons for the year, compared to a measured suspended-sediment discharge of $108,125,500$ tons. The suspended-sediment discharge was about 95 percent of the total sediment discharge, and the bed-material discharge, 15,800,000 tons, was about 14 percent of the total sediment discharge. These percentages probably are typical for ary years except those having extreme conditions.

\section{SUMMARY}

An average of about 45 percent of the flow at St. Louis is from the Missouri River, which was partly controlled by reservoirs raving a total capacity of $90,300,000$ acre-feet in 1956. The Mississippi River at Alton, Ill., upstream from the Missouri River, was partly controlled by lakes and reservoirs having a total capacity of $4,890,000$ acre-feet in 1956.

The relative rates of increase of width, depth, and velocity with discharge at the MacArthur Bridge can be expressed by the simple power functions

$$
\begin{aligned}
b & =680 Q^{0.07} \\
\bar{y}_{0} & =0.16 Q^{0.43} \\
\bar{u} & =0.0092 Q^{0.50}
\end{aligned}
$$

The average recurrence interval of the peak discharge in July 1951 of $782,000 \mathrm{cfs}$ is 9 years, and the average recurrence interval of a discharge of $990,000 \mathrm{cfs}$ or more is 100 years. Peak discharges 
and minimum discharges will be less extreme in the future than in the past because of the increased storage capacity in the drainage basin.

The flows of the Missouri and upper Mississippi Rirers have not become mixed at St. Louis; so the river has a lateral gradient of suspended-sediment concentration. The concentration near the west bank has been as much as $2,400 \mathrm{ppm}$ greater than the concentration near the east bank.

Suspended-sediment discharges from April 1948 to Sentember 1958 ranged from 4,250 to 7,010,000 tons per day and averaged 496,000 tons per day. Mean concentrations for water years decrsased steadily from $1,690 \mathrm{ppm}$ in 1949 to $403 \mathrm{ppm}$ in 1956, but they increased to 756 ppm in 1958. Effects of the new reservoirs in the Missouri River basin on the concentration were obscured by the close relation of concentration to streamflow.

The measured suspended-sediment discharge averaged 47 percent clay, 38 percent silt, and 15 percent sand. Variations of particle size were due mainly to differences in the source areas of the sediment.

Most of the bed material in the main flow is between 0.125 and 1.00 $\mathrm{mm}$ in diameter. The average of median diameters is related to the discharge for periods of 1 year and longer. Geometric cuartile deviations of the bed material ranged from 1.1 to 2.5 and areraged 1.5.

The mean bed elevation from stations 275 to 1,800 ranged from 355.1 to 364.4 feet above mean sea level and was related to the median diameter of bed material by the regression equation $h_{b}=363.0-7.8 d_{50}$, for which the standard error of estimate was 0.91 foot.

The resistance to flow as measured by Manning's $n$ ranged from 0.024 to 0.041 and was related to the discharge and mean velocity but not to the shear velocity. Normal dune height is 2-8 feet, and average length is about 250 feet. When the resistance to flow was low, much of bed was fairly flat and the few dunes were much longer than the average. Data obtained at St. Louis confirm Einstein's relation of $\bar{u} / u_{*}{ }^{\prime}$ to $\Psi^{\prime}$ very well except for low values of $\Psi^{\prime}$. Loops in the relation of gage height to fairly high discharge are caused by a combination of changes in roughness and turbulence constant.

Turbulence constants (Von Karman's $k$ ) computed from velocity measurements at 5-10 points in the vertical and from routine velocity measurements at 2 points in the vertical averaged 0.35 and 0.33 , respectively. Turbulence constants were fairly consistent with those reported by Einstein and Chien (1955).

The exponent $z_{1}$ of the vertical distribution of consentration for different size ranges varied with about the 0.77 power of the fall velocity. Except for the difference between the theoretical variation and the actual variation of $z_{1}$ with changing fall velocity, the theoreti- 
cal equation for the vertical distribution of sediment concentration seems to apply reasonably well for the Mississippi River at St. Louis.

The relations of computed bedload discharge to the measured bedmaterial discharge and to the mean velocity indicated that the most suitable methods for computing bedload discharge of the Mississippi River and similar rivers are the modified Einstein, Schoklitsch, and Meyer-Peter and Müller methods. The relations of computed bedmaterial discharge to the measured bed-material discharge ard to the mean velocity indicated that the most suitable methods for computing bed-material discharge are the modified Einstein procedur? or the addition of the unmeasured sediment discharge from Colby's procedure (1957) to the measured bed-material discharge when data on velocity, concentration, and particle-size distribution are available; the Straub equation is the most suitable method when such data are not available. Measured suspended-sediment discharge averaged about 95 percent of the total sediment discharge, and the bed-material discharge averaged about 14 percent of the total sediment discharge.

\section{LITERATURE CITED}

American Standards Association, 1958, American standard letter symbols for hydraulics: ASA Y10.2-1958.

Anderson, A. G., 1942, Distribution of suspended sediment in a naturel stream: Am. Geophys. Union Trans. 23d ann. mtg., pt. 2, p. 678-683.

Bagnold, R. A., 1956, The flow of cohesionless grains in fluids: Royal Soc. [London] Philos. Trans. 964, v. 249, p. 235-297.

Carey, W. C., and Keller, M. D., 1957, Systematic changes in the beds of alluvial rivers: Am. Soc. Civil Engineers Proc., Hydraulics Div. Jour., v. 83, Paper 1331, $24 \mathrm{p}$.

Chambers, Julius, 1910, The Mississippi River and its wonderful valley: New York and London, G. P. Putnam's Sons, 308 p.

Colby, B. R., 1957, Relationship of unmeasured sediment discharge to mean velocity: Am. Geophys. Union Trans., v. 38, no. 5, p. 708-717.

Colby, B. R., and Hembree, C. H., 1955, Computations of total sediment discharge, Niobrara River near Cody, Nebraska: U.S. Geol. Survey WaterSupply Paper 1357, $187 \mathrm{p}$.

Corbett, D. M., and others, 1943, Stream-gaging procedure-A manual describing methods and practices of the Geological Survey: U.S. Geol. Survev WaterSupply Paper 888, p. 152-157.

Einstein, H. A., 1950, The bed-load function for sediment transportation in open channel flows: U.S. Dept. Agriculture Tech. Bull. 1026, 71 p.

Einstein, H. A., and Chien, Ning, 1954, Second approximation to the solution of the suspended load theory: California Univ. Inst. Eng. Research, Missouri River Div, sediment ser. 3, 30 p.

- 1955, Effects of heavy sediment concentration near the bed on velocity and sediment discharge: California Univ. Inst. Eng. Research, Missouri River Div. sediment ser. 8, 75 p.

Hubbell, D. W., and Matejka, D. Q., 1959, Investigations of sediment transportation, Middle Loup River at Dunning, Nebraska: U.S. Geo'. Survey Water-Supply Paper 1476, 123 p. 
Inter-Agency Committee on Water Resources, 1958, Some fundamentals of particle size analysis, in A study of methods used in measurem $n$ t and analysis of sediment loads in streams: Rept. $12,55 \mathrm{p}$.

Kalinske, A. A., 1947, Movement of sediment as bed-load in rivers: Am. Geophys. Union Trans., v. 28, p. 615-620.

Keulegan, G. H., 1938, Laws of turbulent flow in open channels: U.S. Natl. Bur. Standards, Jour. Research, v. 21, no. 6, p. 707-741.

Leopold, L. B., and Maddock, Thomas, Jr., 1953, The hydraulic geometry of stream channels and some physiographic implications: U.S. Geol. Survey Prof. Paper 252, $57 \mathrm{p}$.

Meyer-Peter, E., and Müller, R., 1948, Formulas for bed-load transport: Internat. Assoc. Hydraulic Structures Research, 2d mtg., Stockholm, Sweden, p. 39-64.

Pafford, R. J., 1959, Operation of Missouri River main-stem reservoirs: Am. Soc. Civil Engineers Trans., v. 124, no. 2984.

Rubey, W. W., 1933, Settling velocities of gravel, sand, and silt particles: Am. Jour. Sci., 5th ser., v. 25, no. 148, p. 332.

Sayre, W. W., and Albertson, M. L., 1959, The effect of roughness spacing in rigid open channels: Fort Collins, Colo, Colorado State Univ., 78 p.

Searcy, J. K., 1955, Floods in Missouri, magnitude and frequency: U.S. Geol. Survey Circ. 370, 126 p.

Searcy, J. K., Baker, R. C., and Durum, W. H., 1952, Water resources of the St. Louis area, Missouri and Illinois: U.S. Geol. Survey Circ. 216, 55 p.

Shulits, Samuel, 1935, The Schoklitsch bed-load formula: Engineering, v. 139, p. 644-646, 687.

Thomas, N. O., and Harbeck, G. E., Jr., 1956, Reservoirs in th? United States: U.S. Geol. Survey Water-Supply Paper 1360-A, 99 p.

U.S. Congress, 1935, 73d Cong., 2d sess., H. Doc. 238, p. 1124-1138 (Missouri River).

Vanoni, V. A., 1946, Transportation of suspended sediment by water: Am. Soc. Civil Engineers Trans., v. 111, p. 67-133.

Vanoni, V. A., and Brooks, N. H., 1957, Laboratory studies of tl $\geqslant$ roughness and suspended load of alluvial streams: California Inst. Technology, Missouri River Div. sediment ser. 11. 
